\title{
Grain legume production and use in European agricultural systems
}

\section{Watson, Christine A.}

2017

Watson, C A , Reckling , M , Preissel , S , Bachinger , J , Bergkvist , G , Kuhlman , T , Lindström , A K, Nemecek , T , Topp , C F E , Vanhatalo , A O , Zander , P , Murphy-Bokern , D \& Stoddard , F L 2017, ' Grain legume production and use in European agricultural systems ' , Advances in Agronomy, vol. 144 , pp. 235-303 . https://doi.org/10.1016/bs.agron.2017.03.003

http://hdl.handle.net/10138/308327

https://doi.org/10.1016/bs.agron.2017.03.003

unspecified

acceptedVersion

Downloaded from Helda, University of Helsinki institutional repository.

This is an electronic reprint of the original article.

This reprint may differ from the original in pagination and typographic detail.

Please cite the original version. 


\section{Advances in Agronomy}

\section{Grain legume production and use in European agricultural systems}

Christine A Watson ${ }^{1,2}$, Moritz Reckling ${ }^{2,3}$, Sara Preissel ${ }^{4}$, Johann Bachinger ${ }^{3}$, Göran Bergkvist ${ }^{2}$, Tom Kuhlman ${ }^{5}$, Kristina Lindström ${ }^{6}$, Thomas Nemecek ${ }^{7}$, Cairistiona FE Topp ${ }^{1}$, Aila Vanhatalo ${ }^{8}$, Peter Zander ${ }^{4}$, Donal Murphy-Bokern ${ }^{9}$ and Fred L. Stoddard ${ }^{8,10}$

1. Crop \& Soil Systems Research Group, SRUC, West Mains Road, Edinburgh, EH9 3JG, UK

2. SLU, Department of Crop Production Ecology, Swedish University of Agricultural Sciences, Box 7043, Uppsala SE-750 07, Sweden

3. Institute of Land Use Systems, Leibniz Centre for Agricultural Landscape Research (ZALF), Eberswalder Str. 84, 15374 Muencheberg, Germany

4. Institute of Socio-Economics, Leibniz Centre for Agricultural Landscape Research (ZALF), Eberswalder Str. 84, 15374 Muencheberg, Germany

5. retired, formerly with Wageningen Economic Research, P.O. Box 29703, 2502 LS Den Haag

6. Department of Environmental Sciences, P.O. Box 65, Viikinkaari 2a, FIN-00014 University of Helsinki, Finland

7. Agroscope, Institute for Sustainability Sciences, 8046 Zurich, Switzerland

8. Department of Agricultural Sciences, P.O. Box 27, Koetilantie 3, FIN-00014 University of Helsinki, Finland

9. Kroge-Ehrendorf, Lohne 49393, Germany

10. Present address: Department of Food and Environmental Sciences, Viikki Plant Science Centre, FIN-00014 University of Helsinki, Finland

Published in Advances in Agronomy 144: 235-303. Doi: 10.1016/bs.agron.2017.03.003

\section{Contents}

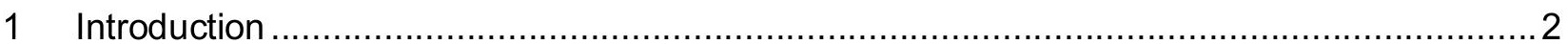

2 The changing role of legumes in European agriculture .................................................. 3

3 Provisioning Services from grain legumes in European agricultural systems .................... 5

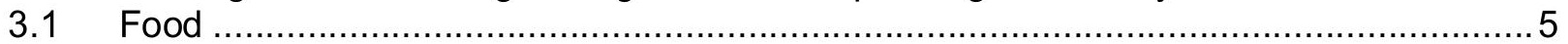

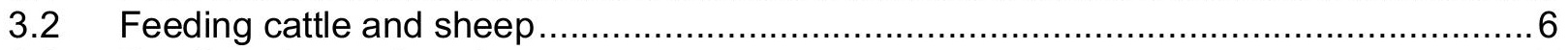

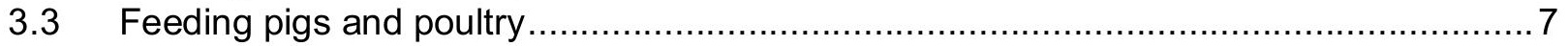

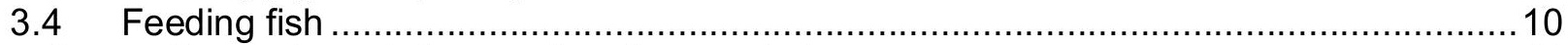

4 Supporting and regulating services from grain legumes ............................................. 11

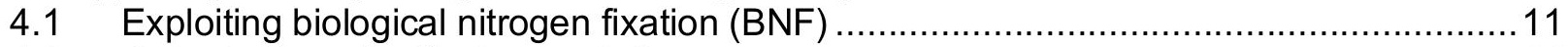

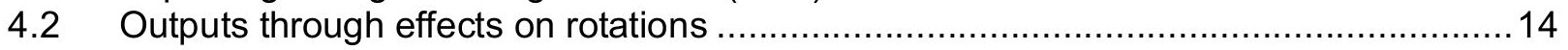

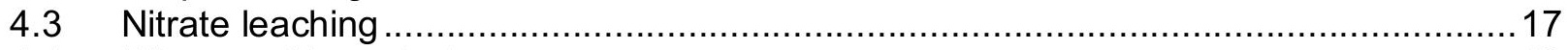

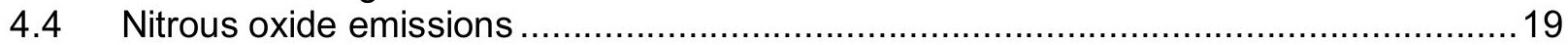

4.5 Agro-biodiversity and climate change adaptation ............................................. 20

4.6 Environmental effects in product life cycles ............................................................21

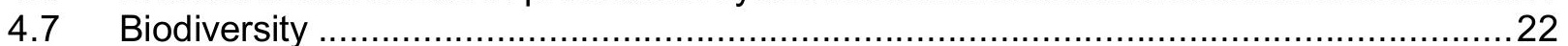

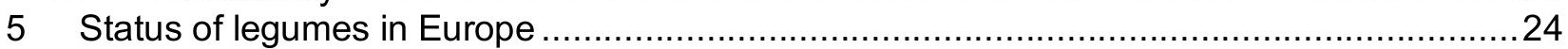

$5.1 \quad$ Changes in EU production of grain legumes over time ........................................24

5.2 Lessons for European producers from other developed regions ..............................27

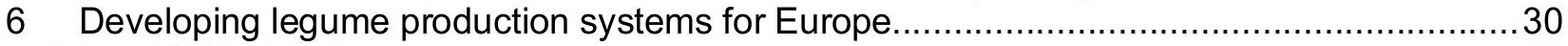

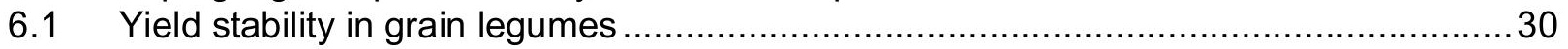

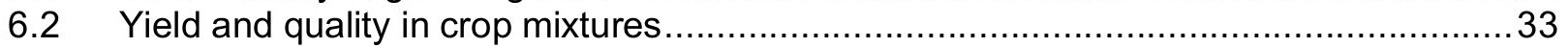

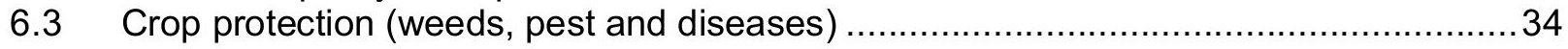

6.4 Soil management, organic matter and soil structure ........................................... 36 


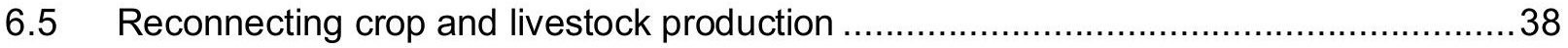

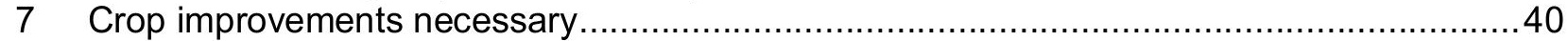

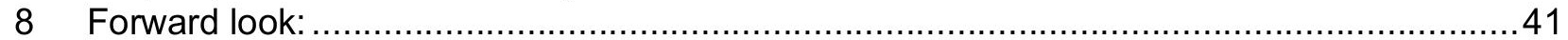

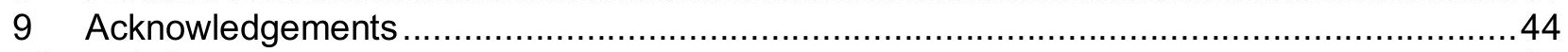

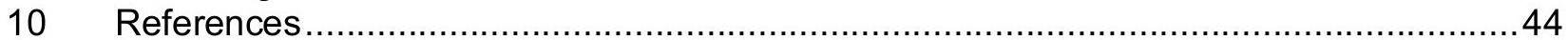

\section{Abstract}

There is a great demand for high-protein materials for livestock feed in Europe and European agriculture has a deficit of about $70 \%$ high protein materials of which $87 \%$ is met by imported soybean and soy meal. This reflects the fact that grain legumes are currently under represented in European agriculture and produced on only $1.5 \%$ of the arable land in Europe compared with $14.5 \%$ on a worldwide basis. Several grain legumes have the potential to replace at least some of the soya currently used in the diets of monogastric animals, ruminants and fish. There are also opportunities for greater use of legumes in new foods. Here we review the contribution of ecosystem services by grain legumes in European agriculture starting with provisioning services in terms of food and feed and moving on to the contribution they make to both regulating and supporting services which are in part due to the diversity which these crops bring to cropping systems. We explore the need to understand grain legume production on the time scale of a rotation rather than a cropping season in order to value and manage the agronomic challenges of weed, pests and diseases alongside the maintenance or improvement of soil structure, soil organic matter and nutrient cycling. A review of policy interventions to support grain legumes reveals that until very recently these have failed to make a difference in Europe. We contrast the European picture with the interventions that have allowed the development of grain legume production in both Canada and Australia. Whether farmers choose to grow more legumes will depend on market opportunities, the development of supply chains and policy support as well as technical improvements of grain legume production such as breeding of new varieties and management development to improve yield stability. However, to really increase the production of grain legumes in Europe the issues are far more wide reaching than agronomy or subsidy and require a fundamental rethinking of value chains to move grain legumes from being niche products to mainstream commodities.

Keywords: Ecosystem services, livestock feed, agricultural policy, crop rotations, systems analysis, nitrogen fixation

\section{Introduction}

Legumes are the second most important family of agricultural crop species after grasses worldwide and are used for both grain and forage, but they are underrepresented in European cropping systems which are dominated by cereals and non-legume oilseeds. This situation has been the subject of public debate in Europe over the last decade and it is now widely acknowledged that grain legumes have the potential to contribute more to European agricultural 
systems by improving the agronomic performance of cropping systems and providing protein-rich food and feed and helping to reduce European dependence on imported protein. Grain legume production contributes widely to ecosystem services by its low reliance on synthetic fertilizers; reduced greenhouse gas emissions; increased diversification of the crop rotation with concomitant increases in above- and below-ground biodiversity and changes in weed, pest and disease pressures; and changes in soil fertility and carbon storage. This combination of ecosystem services (Millennium Ecosystem Assessment, 2005) related to legume production provides internal (market and non-market) and external effects and raises a number of questions for value chain developers: what are the effects of legume production for farmers; what are the innovation challenges; and how can changes in European farming systems be achieved. This review examines these questions in the context of the sustainable development of Europe's agricultural and food systems, and takes a systems view as ultimately, the developments we are considering all depend on the decisions made by Europe's farmers who depend on production options, market developments and policies that altogether influence their decisions. We use the term "grain legume" in its broadest sense, to indicate a legume of which the seed is the main harvested component, thus including the oilseeds soybean and groundnut, and we follow the FAO in restricting the term "pulse" to the starchy legumes and lupins, excluding the oilseeds.

\section{The changing role of legumes in European agriculture}

The use of legumes in cropping has effects that range from the field to the global scale. The global impacts are particularly relevant in Europe as a driver of efforts to restore the use of legumes. Grain legumes were grown on $14.5 \%$ of the global arable cropped area in 2014 , accounting for $12.5 \%$ of the production of all grain crop produce (cereals, pulses and oilseeds) (FAOstat, 2016), but in the EU the corresponding figure is only $1.5 \%$ of the arable area, dominated by soybean, pea and faba bean in that order (Eurostat, 2016). Therefore, the role of grain legumes in European cropping systems is about $10 \%$ of their average role in cropping systems world-wide.

This low level of grain legume production is the result of a long-term trend over at least five decades. During this period, the EU28 achieved remarkably high levels of self-sufficiency in key agricultural commodities. It is now more than $100 \%$ self-sufficient in the major meats (pigmeat, poultry, beef), milk, and cereals (FAOstat, 2016). This means the EU is a net exporter in of these commodities. Using data from FAOstat, we estimate that the total consumption of protein derived from tradable arable crop products (import + EU production - export) was 55 million tonnes (M t) in 2011 , of which $52 \%$ is provided from cereal grains. About $60 \%$ of this cereal protein is fed to animals to support these high levels of self-sufficiency in livestock products. In addition, forage 
maize provided $3.9 \mathrm{M}$ t of protein, almost all for beef and milk production. When all supplies and trade are considered, the EU is $69 \%$ self-sufficient in tradeable plant protein. Nevertheless, highprotein crop commodities, mostly from oilseed residues and pulses, are an essential component of cereal-based compound feeds, and are in deficit by $71 \%$, of which $87 \%$ is met by imported soybean and soy meal. These data confirm other assessments based on industry data that the EU deficit in high-protein materials is around 70\% (Houdijk et al., 2013; Bouxin, 2014). Thus, European agriculture can be characterised as reliant on a combination of reactive $\mathrm{N}$ in fertilizers and in imported feeds, allowing arable land to be allocated to high-yielding cereals and oilseeds (especially oilseed rape). A number of forces have come together since 1960 to result in this situation: changes in trade policy; technical change in livestock production; and economic growth leading to increased disposable income that in turn leads to increased demand for meat and dairy products (Billen et al., 2012; Lassaletta et al., 2014). Between 1961 and 2011, livestock production in Europe increased in line with consumption that rose from the equivalent of 822 $\mathrm{kcal} / \mathrm{capita} /$ day to $993 \mathrm{kcal} / \mathrm{capita} /$ day with 395 and $170 \%$ increases in poultry and pigmeat respectively (FAOstat, 2016; Figure 1). This was facilitated by intensification in production, particularly for pigs and poultry, associated with a decoupling of livestock production from the land resource base used to provide feed. Changes in trade policy gave European farmers access to low-cost soybean and soy meal. Increases in soy imports align with increases in livestock production, particularly pigs and poultry (Figure 1). The current level of livestock production, based largely on European-grown cereals, is facilitated by the complementary qualities of soybean meal, especially with regard to amino acid profiles. The European ban on animal protein supplements in livestock diets, introduced in the 1990s to prevent the spread of Bovine Spongiform Encephalopathy (BSE) and to the development of similar diseases, increased the use of soybean in livestock diets (Vicenti et al., 2009) causing a sharp increase in soybean imports in the second half of that decade (Figure 1).

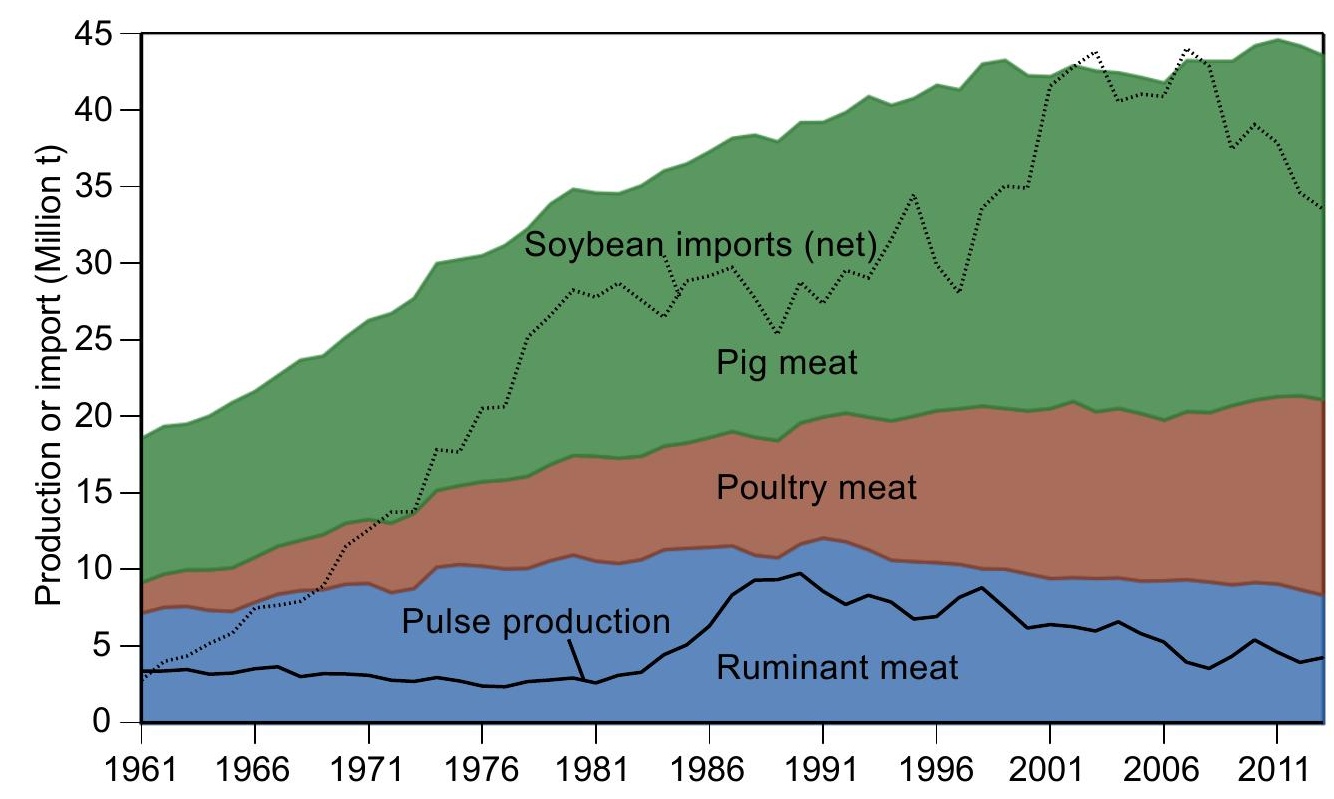


Figure 1: Changes in the production of meat and legumes, along with import of soy, in the EU-27 countries from 1961 to 2013 . Ruminant meat was $87-90 \%$ cattle meat, depending on the year, with the remainder sheep, goat and buffalo. Poultry meat was $89-91 \%$ chicken in the first 5 years, declining to $80-82 \%$ chicken in the last 5 years. For the soybean net imports (dotted line), soybean meal was converted to bean equivalents assuming $79.2 \%$ meal content (US Soybean Export Council 2016), and exports were subtracted. Pulse data (solid line) include pea, faba bean, lupins, common bean, chickpea, lentil, cowpea, and "other pulses" (mostly UK-grown faba bean). All data from FAOstat 2016.

\section{Provisioning Services from grain legumes in European agricultural systems}

Agricultural products, in the context of the ecosystem services concept, are seen as provisioning services to human society. Grain legumes play a major role in this by providing proteins for food and feed products. In the next sections we describe the major benefits / processes / functions obtained from cultivation of grain legumes

\subsection{Food}

Grain legume seeds contain protein, soluble and insoluble fibre, slowly digested starch, microand macro-nutrients, vitamins and numerous bioactive phytochemicals, such as flavonoids and other antioxidants (Bassett et al. 2010; Scalbert et al., 2005; Strohle et al., 2006). The amino acid profile of grain legume protein complements that in cereals. Grain legumes have played an important role in human diets for thousands of years. Grain legumes contain $20-45 \%$ protein compared with $7-17 \%$ in cereals (Day 2013). The protein content ranges from $20-25 \%$ in common bean (Phaseolus vulgaris L.), lentil (Lens culinaris Medik.) and pea, to over $40 \%$ in soybean and yellow lupin (L. luteus L.). Plant products based on soybean can reduce risks to cardiovascular health (Sirtori et al., 2009) through lowering cholesterol and controlling hypertension (Harland and Haffner, 2008). Consumption of soybean and lupin products has been shown to reduce cholesterol in humans (Sirtori et al., 2012), and grain legumes may also be useful in the diet of diabetics (Bertoglio et al., 2011), although the mechanisms of these effects remain to be elucidated (Arnoldi et al., 2015). Some of the bioactive components, such as tannins and phytate, affect palatability, digestibility and nutrient availability. Many, such as phytohaemagglutinin of common bean and trypsin inhibitors of most species, are substantially or completely denatured by cooking. Others, such as phytate (myoinositol hexakisphosphate) and raffinose series oligosaccharides, can be degraded by endogenous enzymes during germination or by exogenous enzymes in a food matrix. Still others, such as vicine and convicine in faba bean, require a breeding solution. The main legume storage proteins are globulins, defined by their solubility in saline solution, and are easily extracted for use in dairy analogue products. 
Further technological input, such as the pressure-heat treatment in extrusion, allows textured vegetable protein to be produced to emulate meat on the plate and in the mouth. Soybean-based milk and textured protein products are familiar in many countries, and adaptations to the technology are under investigation so that other crops, such as narrow-leafed lupin or faba bean, can be used (Jiang et al., 2016; Stephany et al., 2016).

Davis et al. (2010) used LCA (life cycle assessment) to examine the full spectrum of environmental effects of introducing more grain legumes in human nutrition. Replacing meat by peas led to a reduction of global warming, eutrophication, acidification, and land use, but a completely vegetarian pea burger meal required the same amount of energy input as the meatcontaining meals, due to intensive processing.

\subsection{Feeding cattle and sheep}

Grain legumes can be utilized flexibly in diets of all ruminant species either in concentrate compound feed or as whole crop forage. Unlike monogastrics, ruminants are not susceptible to most of the antinutritional factors of grain legumes owing to the microbial fermentation taking place in their forestomachs (Dixon and Hosking, 1992). LCA studies show advantages of replacing soybean by European legumes in ruminant feed. Using locally produced pea and oilseed rape (Brassica napus L. ssp. oleifera Metzg.) to replace soybean resulted in a $15 \%$ reduction in the GHG carbon footprint of milk (Sasu-Boakye et al., 2014). Similarly, Baumgartner et al. (2008) found lower adverse environmental impacts for replacing soybean meal by European legumes for feeding dairy cows, with the exception of eutrophication. The feasibility of the use of grain legumes in ruminant diets is determined not only by their chemical composition and how they complement the forage component of the diet, but also by the rate and extent of degradation of nutrients in the rumen. The degradability of grain legume protein in the rumen is often over $80 \%$, similar to that of most cereal grains (Dixon and Hosking, 1992; Luke, 2016). Using methods such as heat treatment to improve availability of protein to the animal have seldom been successful in terms of added value for milk production as shown for pea (Petit et al., 1997), narrow-leafed lupin (White et al., 2007) and faba bean (Ramin et al., 2015). This may be attributed to the suboptimal amino acid profile in undegraded grain legume protein, which is especially low in the limiting amino acids such as methionine (White et al., 2007; Van der Pol et al., 2008; Puhakka et al., 2016). This suggests that supplemental amino acids may be necessary when grain legumes are fed to high-producing dairy cows. Pea and faba bean starches have lower degradability in the rumen than cereal starches (Larsen et al., 2009) and lupins have higher metabolizable energy content (White et al., 2007) than cereal grains, which may contribute to the supply of metabolizable energy to the ruminant animal and explain why replacement of cereal grains with grain legumes in dairy cow rations often increases milk 
production (Dixon and Hosking 1992, White et al., 2004, White et al., 2007, Puhakka et al., 2014), but not always (Khalili et al., 2002).

As soybean meal (SBM) is usually considered the standard supplementary plant protein source in animal feeds, most studies examining the effects on protein sources on livestock production use isonitrogenous comparisons, with SBM used as the control. This type of research shows for example that SBM can be completely (Petit et al., 1997, Khorasani et al., 2001) or partly (Van der Pol et al., 2008) substituted by pea as the protein source in various stages of lactation of cows without any adverse effect on milk production. The same was shown for substituting SBM by faba bean (Ingalls and McKirdy, 1974, Tufarelli et al., 2012), white lupin (Froidmont and Bartiaux-Thill, 2004) or narrow-leafed lupin (White et al., 2007), with the exception of some studies showing reduced milk protein concentrations.

Rapeseed meal (RSM) is another tradeable protein source that can be partially substituted by grain legumes. Meta-analyses show that most feed evaluation systems overestimate metabolizable protein concentration of SBM relative to rapeseed meal (Huhtanen et al., 2011). Replacement of RSM with pea impaired milk production, but a combination of pea and RSM resulted in similar performance to that of RSM alone (Khalili et al., 2002). In an early study, no difference was found in milk production parameters between faba bean and RSM (Ingalls and McKirdy, 1974), but a recent comparison showed lower milk yields from the use of faba bean (Puhakka et al., 2016). The replacement of a portion of protected RSM with narrow-leafed lupin reduced milk protein concentrations of pasture-fed cows (White et al., 2004). Variation in dairy cow production responses to grain legume supplementation may be attributed to the various types of forages used in the experiments, as well as to variable effects of grain legumes on dietary dry matter intake (Puhakka et al., 2016). Grain legume - cereal crop mixtures for silage production have proved beneficial in dairy cow feeding (Adesogan et al., 2004; Pursiainen and Tuori, 2006). These effects arise from the energy and protein complementarity of the components providing an appropriate balance between readily fermentable nutrients for microbial protein synthesis in the rumen. Furthermore, mixing grain legume-cereal whole-crop silage with grass-clover (Rondahl et al., 2007) or grass (Lamminen et al., 2015) silages may maintain or increase intake and milk production of dairy cows in comparison to conventional grass-based forage rations.

\subsection{Feeding pigs and poultry}

SBM accounts for $84 \%$ of all the high-protein oilseed meal used in compounded livestock rations worldwide (FAOstat 2016). There are no official data on the use of soy in the various livestock sectors, but Gelder et al. (2008) estimated the allocation of the Dutch-consumed soy to livestock species based on feed formulation and farm practice in the Netherlands, with inclusion rates in 
concentrate feed of $37 \%, 29 \%, 22 \%$ in feeds for broilers, pigs and laying hens, respectively. The inclusion of soy in beef and dairy concentrate feeds was lower at $14 \%$ and $10 \%$ respectively. This results in the following rates of use on a per unit food commodity output basis: beef, 232 g/kg; milk, $21 \mathrm{~g} / \mathrm{kg}$; pork, $648 \mathrm{~g} / \mathrm{kg}$; poultry meat, $967 \mathrm{~g} / \mathrm{kg}$; eggs, $32 \mathrm{~g} / \mathrm{egg}$. These estimates indicate that monogastrics (pigs and poultry) account for at least $80 \%$ of soybean meal use in the Netherlands. Hoste and Bolhius (2010) reported slightly different rates of use of soybean meal as follows: $100 \mathrm{~g} / \mathrm{kg}$ veal produced, $600 \mathrm{~g} / \mathrm{kg}$ of poultry, $11 \mathrm{~g} / \mathrm{kg}$ of raw milk and $330 \mathrm{~g} / \mathrm{kg}$ of eggs. The total industrial feed production in Europe was 155 million tonnes in 2013 (FEFAC, 2014). Our assessment of the FEFAC data agrees with that of Westhoek et al. (2011) that inclusion rates of soy in feed are lower across the EU than suggested by Gelder et al. (2008) for the Netherlands. Nevertheless, it is clear that the increase in the production of monogastric meats is the primary driver behind the increases in the demand for soybean over the last fifty years.

SBM is the standard protein supplement in pig feed (Crépon, 2006; Jezierny et al., 2010) due to its high crude protein (CP) content (44\%) and useful amino acid profile, unmatched by other grain legumes that are deficient in the essential amino acids methionine, cysteine and tryptophan (Gatel, 1994). The use of legumes in monogastric diets is constrained by the presence of antinutritional factors including non-starch polysaccharides (NSP), tannins, phytate, saponins and trypsin inhibitors that have adverse effects on nutrient digestibility and absorption (Gatel, 1994) and can result in reduced feed intake, reduced digestibility or even toxicity (e.g. Huisman and Jansman, 1991). In the past, both reduced pig growth (Crépon, 2006) and increased boar taint indicators (Madsen et al., 1990) have been associated with diets high in pea and faba bean. However, White et al. (2015) and Smith et al. (2013) demonstrated that peas and beans can be used in balanced pig diets without any negative effects on production compared to soybean meal. Research on the use of legumes in both pig and poultry diets shows that processing may be important in allowing greater proportions of grain legumes to be used, for example, increases in starch digestibility as a result of dehulling faba beans have been shown (Nalle et al., 2010). Other effective treatments include dehulling to reduce tannin and fibre content, heat treatments such as extrusion or toasting to denature heat-labile anti-nutritional factors, particle size reduction to increase digestibility through increased surface area, and fractionation to select components rich in nutrients (Woyengo et al., 2014). Fibre-degrading enzymes can be added in order to increase dietary nutrient availability, or diets can be formulated according to the bioavailability of essential amino acids. Pea, faba bean and lupins have all been shown to be suitable as partial substitutes for soybean in broiler diets, although lupins are the least effective because of their high content of indigestible cell walls (Diaz et al., 2006) and faba bean needs to have a low vicine-convicine content (Crépon et al., 2010). These alternatives to soybean have also been shown to be acceptable in egg production (e.g. Laudadio and Tufarelli, 2010). 
Studies using LCA have shown that the main effects of replacing imported soybean with European grain legumes are reduced transport distances, avoided deforestation impacts and rotational benefits. Since soybean is also a legume, the advantages of BNF are present in both systems. Other effects on acidification, energy use, eutrophication, global warming potential, land use, ozone formation and toxicity depend strongly on the basis of comparison, as shown below. Since pea and faba bean are starchy, their use in feed affects the starch cereal component as well as the protein-rich soybean component that they are intended to replace, adding to the complication of the analysis. Production methods, yield levels (Nemecek et al., 2012), and cultivar (Abeliotis et al., 2013) all affect the environmental impact of the legume crop compared with alternatives. Until 2006, LCA studies used the same $1 \% \mathrm{~N}_{2} \mathrm{O}$ emission factor for biologically fixed $\mathrm{N}$ as for mineral and manure fertilizers, but since then IPCC methodology has set the emission factor for biologically fixed $N$ used by the legume to zero (IPCC, 2006). Schwenke et al. (2015) determined that $75 \%$ of a legume crop's $\mathrm{N}_{2} \mathrm{O}$ emission took place after harvest.

Eriksson et al. (2005) compared three scenarios for pig feed formulations: a standard formula with soybean meal, domestic feed (no soybean meal) with a low crude protein level and added synthetic amino acids, and organically produced feed. The first scenario had the lowest environmental impacts for land use, the second for acidification and eutrophication, and the third for energy use and global warming potential. With the exception of eutrophication, conventional (Dourmad et al., 2014, Garcia-Launay et al., 2014) and organic soybean (Dourmad et al., 2014) from Brazil had greater environmental burdens than pea grown in Europe. On a global scale, GHG emissions from soybean and pea per kg were similar when land-use change impacts were taken into account. Garcia-Launay et al. (2014) showed that replacing part of the soybean in the pig rations with rapeseed meal, pea and synthetic amino acids reduced environmental impacts.

Van der Werf et al. (2005) showed that pea resulted in higher impacts than wheat or barley for eutrophication, energy use and climate change. Similarly, Nguyen et al. (2012) found that impact reduction was obtained by partial substitution of soybean meal and cereals in poultry feed with rapeseed meal, grain legumes and cereal co-products (wheat bran, gluten). Baumgartner et al. (2008) found that the main effect of introducing European grain legumes to replace soybean were found in reduced energy demand, reduced greenhouse gas emissions, and reduced ozone formation. Producing the feedstuffs on-farm further reduced the environmental burden. No clear tendency was observed for eutrophication and acidification, while the toxicity tended to be higher for the European legumes because of differences in pesticide use. Effects were determined more by the composition of the whole feed formulas than by the replacement of soybean meal by peas and beans alone. 
Reckmann et al. (2016) assessed three alternative diets with reduced inclusion of soy for gestating and lactating sows as well as growing and finishing pigs, reducing the soy component by (a) using a combination of different feedstuffs (e.g. rapeseed meal, faba bean, and synthetic amino acids), (b) maximising the use of legumes (mainly faba bean), and (c) increasing the amount of synthetic amino acids. These alternative diets were formulated to reduce the crudeprotein content of the diet while maintaining animal productivity. Per $\mathrm{kg}$ of feed, the standard diets was best with regard to global warming, eutrophication, and acidification, and both the standard and amino acid-fortified diets had low impacts on emissions from land use and land-use change. Per kg of pork, however, the amino acid-fortified diet contributed the least in all impact categories, while the legume-maximizing scenario had higher impacts than the standard diet for global warming and land use.

Thus LCA does not show any strategy for monogastric feed production to be a universal panacea, as it demonstrates that benefits in one area such as land-use change are countered by detrimental effects in another area.

\subsection{Feeding fish}

Legume-based products can replace or reduce the need for fish meal for feeding many farmed fish and crustaceans (Trushenski et al., 2006). The potential of a range of plant-based protein sources for fish feed was reviewed by Ayadi et al. (2012). Compounded fish feeds contained a mean of $25 \%$ soybean meal in 2008 , representing $4.5 \%$ of world soybean meal production in that year, and use of other pulse and cereal proteins is increasing (Tacon et al., 2011). Herbivorous fish such as carp (Cyprinus carpio L.) can by definition be raised exclusively on plant-based feeds. Faba bean and pea have been shown to be the most suitable grain legumes for inclusion in diets for Atlantic salmon (Salmo salar L.) (Aslaksen et al., 2007). White lupin (L. albus L.) and pea were equally good for rainbow trout (Oncorhynchus mykiss Walbaum) (Zhang et al., 2012). Narrow-leafed lupin meal can be used at up to $30 \%$ of the diet of rainbow trout (Glencross et al., 2008) and the protein concentrates from this species are efficiently converted by the fish (Zhang et al., 2012). Similarly, Pacific white shrimp (Litopenaeus vannamei Boone) grew well with up to $50 \%$ of the protein in the feed being plant-derived (from Andean lupin, L. mutabilis Sweet) (Molina-Poveda et al., 2013). The presence of some starch helps the formation of feed pellets under heat extrusion, so faba bean or pea flour can replace some of the wheat or other cereal starch in the formulation.

As with pigs and poultry, there is a need to account for the anti-nutritional factors present in grain legumes. For example, saponins are known to reduce growth in salmonids (e.g. Krogdahl et al., 2015), and faba bean is better in this regard as it contains around $4.3 \mathrm{~g} \mathrm{~kg}^{-1}$ of saponins compared to $43 \mathrm{~g} \mathrm{~kg}^{-1}$ in soybean (Fenwick and Oakenfull, 1983). 


\section{Supporting and regulating services from grain legumes}

Besides their direct use in food and feed, legumes offer supporting services in production of subsequent crops and regulating services that are not marketable in conventional settings. Supporting services include biological nitrogen fixation and other rotational effects, and regulating services include positive externalities of legumes related to nutrient management, greenhouse gas impacts of agriculture and biodiversity conservation. These are outlined in the following sections.

\subsection{Exploiting biological nitrogen fixation (BNF)}

The capacity of legumes, in conjunction with rhizobium symbionts, to fix atmospheric nitrogen is one of the key features distinguishing them from other arable crops. The amount of nitrogen fixed by legumes depends not only on species and cultivar but also on environmental factors such as temperature, water availability (see examples for pea and faba bean grown as sole crops, Table 1 ), and the availability of mineral N. Grain legumes in Europe were calculated to fix an average of $133 \mathrm{~kg} \mathrm{ha}^{-1}$ totalling $225 \mathrm{Gg}$ of $\mathrm{N}$ in 2009 (Baddeley et al., 2013). The three major contributors were faba bean, pea, and soybean in that order, with 10-fold less $\mathrm{N}$ fixed by (in order) lupin, vetch, common bean, lentil, and chickpea (Baddeley et al., 2013). The values for soybean and common bean were lower than might be expected from their areas, on account of their low published Ndfa values.

Differences among the rhizobium strains in the root nodules influence the BNF capacity of the crop, depending on their compatibility with the host and their competitiveness for nodulation. The relationship between the symbiotic partners is very complex and consists of interactions at many levels (for reviews see Franche et al., 2009; Lindström and Mousavi, 2010). Inoculants comprising effective, nitrogen-fixing bacteria are commercially available, often selected for regional or national adaptation. Since nodulation properties depend on both host and rhizobium, it is recommended that inoculants should be used to ensure good nodulation and BNF in newly introduced crops. Even if there are naturalized rhizobia in the soil, inoculation can optimize BNF and increase crop yield (Denton et al., 2013). The inoculants are selected for high rates of BNF and for competitiveness in field conditions (Yates et al., 2011). Genetic determinants in rhizobia contributing to host-specificity of nodulation are fairly well known. Determinants contributing to effectiveness of BNF are still to be unravelled, but Österman et al. (2015) detected bacterial genes associated with good effectiveness in the forage legume, goat's rue (Galega orientalis 
Lam.). Breeding for enhanced BNF has been reported for crop legumes (Herridge and Rose, 2000), but no commercial success stories have been reported due to the complex nature of this trait.

An inverse relationship between fixation rate and available mineral nitrogen is widely accepted (Salvagiotti et al., 2008). Many agronomists and farmers advocate the use of "starter" nitrogen fertilizer at $20-40 \mathrm{~kg} \mathrm{ha}^{-1}$, to allow the crop to establish while the nitrogen-fixing symbiosis initiates. When available mineral $\mathrm{N}$ in the soil was less than this amount, there was a benefit to final yield in many experiments on pea in Canada (McKenzie et al., 2001). Similarly, 8-24 kg ha-1 of starter $\mathrm{N}$ assisted soybean establishment in cool soils in the USA, with little effect on subsequent Ndfa (Osborne and Riedell, 2011). Thus there seems to be little reason to reject the use of starter nitrogen for grain legume crops. 
Table 1 Variation in $\mathrm{N}$ fixation and Ndfa with species, cultivar and European country as sole crops and for pea intercropped with spring barley

\begin{tabular}{|c|c|c|c|c|c|c|c|c|}
\hline \multirow[t]{2}{*}{ Legume } & \multirow[t]{2}{*}{ Cultivar } & \multirow[t]{2}{*}{ Country } & \multicolumn{2}{|c|}{ Sole crop } & \multicolumn{2}{|c|}{ Intercrop with spring barley ${ }^{a}$} & \multirow[t]{2}{*}{ Method $^{b}$} & \multirow[t]{2}{*}{ Reference } \\
\hline & & & $\mathrm{N}$ fixed $(\mathrm{kg} / \mathrm{ha})$ & pNdfa (\%) & $\mathrm{N}$ fixed (kg/ha) & pNdfa (\%) & & \\
\hline Pea & Baccara & FR & $110-204$ & $47-77$ & $71-209$ & $58-91$ & NA & Corre-Hellou et al. (2006) \\
\hline Pea & Agadir & DK & 150 & $62-72$ & 90 & $73-87$ & ID & Hauggaard-Nielsen et al. (2008) \\
\hline Pea & Baccara & DK, UK, IT, FR, DE & $61-154$ & $47-81$ & $32-78$ & $52-84$ & ID & Hauggaard-Nielsen et al. (2009) \\
\hline Pea & Bohatyr & $\mathrm{DK}$ & 140 & 76 & 65 & 86 & ID & Andersen et al. (2004) \\
\hline Pea & Bodil & DK & $128-215$ & $53-68$ & $27-74$ & $79-84$ & ID & Jensen (1996) \\
\hline Pea & Focus & DK & 120 & 89 & 30 & 95 & ID & Hauggard-Nielsen et al. (2001) \\
\hline Pea & Baccara & FR & $238^{\mathrm{c}}$ & 84 & & & ID & Voisin et al. (2002) \\
\hline Pea & Ballet & PT & $27-55$ & $29-74^{d}$ & & & ID & Carranca et al. (1999) \\
\hline Pea & Nitouche & FR & $96-102^{c}$ & $60-65$ & & & ID & Corre-Hellou and Crozat (2005) \\
\hline Pea & Lucy & FR & $173-218$ & $71-82$ & & & NA & Naudin et al. (2010) \\
\hline Faba bean & 16 genotypes & FR & $34-253$ & $40-83$ & & & NA & Duc et al. (1988) \\
\hline Faba bean & Favel & PT & 73-79 & $69-73 a$ & & & ID & Carranca et al. (1999) \\
\hline Faba bean & Columbo & DK & $160-170$ & $70-75$ & & & ID & Hauggaard-Nielsen et al. (2008) \\
\hline Lupin, NL & Prima & DK & $140-150$ & 76 & & & ID & Hauggaard-Nielsen et al. (2008) \\
\hline Lupin, white & Multitalia & IT & $178^{c}$ & 76 & & & ID & Sulas et al (2016) \\
\hline Chickpea & Cutivar 510 & PT & 23 & $81^{d}$ & & & ID & Carranca et al. (1999) \\
\hline Soybean & 3 varieties & DE & $43-100$ & $43-55$ & & & NA & Zimmer et al. (2015) \\
\hline Soybean & Maple Arrow & $\mathrm{CH}$ & $25^{c}$ & $41-47$ & & & NA & Oberson et al. (2007) \\
\hline Soybean & Apache & AT & & $40-52$ & & & NA & Schweiger et al. (2012) \\
\hline
\end{tabular}

${ }^{a}$ All studies used the replacement design, each species being sown at half its sole crop density; ${ }^{b}$ Method to determine $\mathrm{N}$ fixation (NA, natural abundance and ID isotope dilution); ${ }^{\mathrm{c}} \mathrm{N}$ fixed was measured in shoots plus roots; ${ }^{\mathrm{d}} \mathrm{pNdfa}$ in pods 
While the total amount of $\mathrm{N}$ fixed is generally higher in grain legumes grown as sole crops than in intercrops, the proportion of $\mathrm{N}$ derived from fixation (\% $\mathrm{Ndfa}$ ) is higher in intercrops, as the cereal takes up any mineral $\mathrm{N}$ in the soil, forcing the legume to rely on BNF (Bedoussac et al., 2015). This is shown in a range of pea - barley mixtures in different countries (Table 1) as well as in other mixtures such as pea - wheat (Ghaley et al., 2005). $\mathrm{N}$ fixation is affected by the frequency of legumes in the rotation, with continuous pea cropping reducing the proportion of $\mathrm{N}$ derived from the atmosphere to $15 \%$ compared with an average of $55 \%$ in peas grown every second, third or fourth year, but the mechanisms for this remain unclear (Knight, 2012).

Phosphorus, potassium and sulphur deficiencies affect BNF directly by affecting plant growth and indirectly by a series of mechanisms including nodule growth and activity (Divito and Sadras, 2014). Other stresses reducing BNF include sub- or supra-optimal soil pH (Vargas and Graham 1988), toxic elements (Obbard and Jones, 2001; Fox et al., 2007), some agrochemicals including organochlorine pesticides (Fox et al., 2007), pest or pathogen attack (Corre-Hellou and Crozat, 2005), and low availability of micronutrients (particularly boron and molybdenum) (O'Hara et al., 1988; Brodrick et al., 1992; Carpena et al., 2000). Positive interaction with arbuscular mycorrhizal fungi have been postulated, but has proven hard to validate in the field (Chalk et al., 2006).

\subsection{Outputs through effects on rotations}

Introducing legumes into cropping systems often positively affects the nutrient status, organic matter, soil structure, and disease inoculum levels in the soil increasing subsequent crop yields. These are therefore internal effects resulting indirectly in market outputs, i.e., the increased yields in subsequent crops. In practice, this is due to a combination of 'break-crop' and 'nitrogen' effects (Chalk, 1998). The nitrogen effect comprises the provision of $\mathrm{N}$ to the subsequent crops. The break-crop effect occurs when rotations that lack crop diversity, as are found in many cereal production systems in Europe, are 'broken' by a broad-leaved crop or a rotational grass-clover ley (Robson et al., 2002). The components of the break-crop effect include reductions in weeds, pests and diseases (Prew and Dyke, 1979; Stevenson and van Kessel, 1997) and improvements in soil structure (Chan and Heenan, 1996). Legume-specific break-crop effects include changes in soil microbiology, particularly the enhancement of growth of some beneficial soil microorganisms (Crews and Peoples, 2004; Maimaiti et al., 2007; Peoples et al., 2009). One of the mechanisms involved is that hydrogen gas, a by-product of BNF, supports the growth of hydrogen-utilising bacteria in the rhizosphere of the legume nodule, which in turn supports populations of soil fauna (La Favre and Focht, 1983) and of plant growth-promoting rhizosphere bacteria (Dong et al. 2003; Lugtenberg and Kamilova, 2009; Golding and Dong, 2010). The root growth of many crops is better following legumes than after non-legumes, for example, the root 
density of broccoli in the subsoil was significantly higher following narrow-leaved lupin than after winter oilseed rape (Thorup-Kristensen, 1993), but it is unclear how this effect is partitioned among changes in the soil microbial environment, soil structure and nutrient availability. The origin of the term 'break-crop effect' is attributed to the breaking of the cycles of soil-borne root diseases such as take-all root rot (Gaeumannomyces graminis (Sacc.) Arx \& D.L. Olivier) of cereals that die within a year in the absence of a suitable host. Similarly, root-lesion nematodes (Pratylenchus spp.) infest many crops, but some cultivars of faba bean suppress the growth of $P$. neglectus (Rensch) Filipjev and Schuumans Stekhoven, reducing the infestation of the subsequent crop (Yunusa and Rashid, 2007). These improvements of the root health of following crops are often most easily detected in their improved $\mathrm{N}$ nutrition, although the effect is not one of $\mathrm{N}$ provision (Kirkegaard et al., 2008). The impact on the following crop is to some extent soiltype dependent, as the $\mathrm{N}$ in root-zone residues can significantly promote root growth in sandy soil but not detectably in loamy soil (Jensen et al., 2004).

The precrop effect is generally described in terms of nitrogen, but the residues of grain legumes can also influence phosphorus availability to the following crop. Grain legume roots exude a range of carboxylates that solubilize phosphate from insoluble forms including calcium and iron salts that are immobile in the soil and generally considered unavailable to plants. The quantity of carboxylates released depends on the concentration of plant-available phosphorus in the soil, with low levels promoting greater release. The number and type of carboxylates depend on the species, with faba bean releasing only malic and citric acids whereas some lupins release up to eight acids (Egle et al., 2003). Phosphorus uptake ability ranged 3-fold among 50 faba bean accessions in a germplasm survey, and in a pot test, the difference in release of soil phosphate was detectable in the following wheat sown immediately after the beans were harvested (Rose et al., 2010).

In a survey, farmers estimated that wheat grown after grain legumes produced $0.6 \mathrm{t} \mathrm{ha}^{-1}$ more yield than when grown after cereals in Belgium, central Spain and Switzerland, and $0.9 \mathrm{t} \mathrm{ha}^{-1}$ in Germany and northern Spain (von Richthofen et al., 2006a). In a meta-analysis including 300 comparisons, wheat grain yields were $1.2 \mathrm{t} \mathrm{ha}^{-1}$ greater after legumes than after wheat (Angus et al. 2015). Estimates of the effects on the optimum nitrogen fertilizer requirements of following crops, based on expert estimations, observations of farmer practice, models and additional crop $\mathrm{N}$ take-up in experiments, averaged $23-31 \mathrm{~kg} / \mathrm{ha}$ (Preissel et al., 2015). These values are much lower than estimates of the residual $\mathrm{N}$ of legumes, which can be explained by the larger $\mathrm{N}$ demand of high yielding subsequent crops.

The size of the nitrogen-related yield effect to the following cereal depends on the species of the legume crop, with high-biomass crops such as faba bean generally leaving more residue giving a 
greater effect than low-biomass crops such as chickpea (Table 4). The pre-crop effect on yield further depends on the amount of $\mathrm{N}$ fertilizer used as well as on the species of the pre-crop and the site (Table 2; see also Preissel et al., 2015 for a meta-analysis on an overlapping data set). Unfertilized cereals gained 1-3 $\mathrm{t} \mathrm{ha}^{-1}$ in experiments in Denmark, Switzerland, Austria, Germany and the UK. With increasing fertilization, the importance of the legume's nitrogen residue diminishes and the yield effects become more heterogeneous, as shown by comparing results from experiments located near each other in the UK or in Switzerland and Bavaria (Table 4). High yield gains in other highly fertilized trials show the importance of non-nitrogen effects of the legume pre-crop and in absolute numbers most of the yield gain often remains at high $\mathrm{N}$ doses (Engström and Lindén, 1999). Other crops besides cereals, such as oilseed rape and potato (Solanum tuberosum L.), also show growth responses to grain legume pre-crops (Jensen and Haahr, 1990; Charles and Vuilloud, 2001) as long as broad-spectrum pathogens such as Sclerotinia sclerotiorum (Lib.) de Bary and Rhizoctonia solani Kühn are controlled in the rotation.

Under optimal fertilization and with full pest and disease management, grain legumes are not a consistently better pre-crop for wheat or barley than other broad-leaved crops or, in some situations, oat (Preissel et al., 2015). While it is difficult to calculate the value of legumes in rotations to crop yield at a large scale, Brisson et al. (2010) suggested that the reduction in the area of legume cultivation in France, resulting from policy and economic changes along with the difficulty of managing root rot diseases of pea, could be part of the reason for the stagnation of cereal yields.

Yield gains of 0.2-1.0 t/ha were typically found in cereals after grain legumes in experiments under Mediterranean conditions in Spain, Italy and Cyprus, regardless of the fertilization level (Table 4; Preissel et al., 2015). In 72 site-years of data from Spain (Preissel et al., 2015), results were mixed partly in favour of the legume (especially faba bean and vetch) and partly in favour of fallow (especially compared to chickpea), with a median difference of $160 \mathrm{~kg} / \mathrm{ha}$ in favour of fallow (López-Bellido et al., 1998; López-Bellido et al., 2001; López-Bellido and López-Bellido, 2001; Melero et al., 2011; Soldevilla-Martinez et al., 2013).

A pre-crop effect also applies to the legume which can be affected by the preceding crop. The mineral nutrient uptake of faba bean and narrow-leafed lupin was influenced by the preceding crop, with oat and, barley, and turnip rape (in the case of lupin) resulting in increased nutrient uptake and grain yield in the legume compared with pre-crops of wheat, rye or other grain legumes (Lizarazo et al., 2015).

Table 2: Yield effects of grain legumes and oilseed rape as pre-crops on subsequent cereals, classified by nitrogen fertilizer rate. The yield effect is the difference $\left(\mathrm{kg} \mathrm{ha}^{-1}\right)$ or percentage 
increase of the yield of the subsequent crop following the break crop compared to the yield of the same crop, usually following the same cereal.

\begin{tabular}{|c|c|c|c|c|c|c|}
\hline \multirow[t]{2}{*}{ Pre-crop } & \multirow[t]{2}{*}{ Crop } & \multirow{2}{*}{$\begin{array}{c}\text { N rate } \\
\left(\mathrm{kg} \mathrm{ha}^{-1}\right)\end{array}$} & \multicolumn{2}{|c|}{ Yield effect } & \multirow[t]{2}{*}{ Country } & \multirow[t]{2}{*}{ Source } \\
\hline & & & $(\%)$ & $\left(\mathrm{kg} \mathrm{ha}^{-1}\right)$ & & \\
\hline \multicolumn{7}{|c|}{ No fertilization (0 kg N ha-1) } \\
\hline \multirow[t]{2}{*}{ Pea } & Wheat & 0 & $114 \%$ & 3109 & $\mathrm{DE}$, Thuringia & $\begin{array}{l}\text { Albrecht and Guddat } \\
(2004)\end{array}$ \\
\hline & Wheat & 0 & $135 \%$ & 2700 & UK, Rothamsted & McEwen et al. (1989) \\
\hline \multirow[t]{5}{*}{ Faba bean } & Wheat & 0 & $104 \%$ & 2759 & DE, Thuringia & $\begin{array}{l}\text { Albrecht and Guddat } \\
(2004)\end{array}$ \\
\hline & Wheat & 0 & $156 \%$ & 3125 & UK, Rothamsted & McEwen et al. (1989) \\
\hline & Barley & 0 & $75 \%$ & 1248 & UK, Rothamsted & Dyke and Slope (1978) \\
\hline & Oats & 0 & $27 \%$ & 920 & DE & Justus and Köpke (1995) \\
\hline & Wheat & 0 & $36 \%$ & 1092 & ES, Andalucia & Melero et al. (2011) \\
\hline \multirow{2}{*}{$\begin{array}{l}\text { Narrow- } \\
\text { leafed lupin } \\
\text { Oilseed } \\
\text { rape }\end{array}$} & Wheat & 0 & $100 \%$ & 1750 & $\mathrm{DE}$, Thuringia & $\begin{array}{l}\text { Albrecht and Guddat } \\
\text { (2004) }\end{array}$ \\
\hline & Wheat & 0 & $11 \%$ & 434 & AT, Lower & Dachler and Köchl (2003) \\
\hline \multicolumn{7}{|c|}{ Moderate fertilization $\left(20-90 \mathrm{~kg} \mathrm{~N} \mathrm{ha}^{-1}\right)$} \\
\hline \multirow[t]{2}{*}{ Pea } & Wheat & 77 & $24 \%$ & 1267 & DE, Bavaria & Panse et al. (1994) \\
\hline & Rye & $45-80$ & $6 \%$ & 550 & $\mathrm{CH}$ & $\begin{array}{l}\text { Charles and Vuilloud } \\
\text { (2001) }\end{array}$ \\
\hline \multirow[t]{3}{*}{ Faba bean } & Wheat & 38 & $26 \%$ & 1085 & UK, Boxworth & $\begin{array}{l}\text { Bowerman and Clare } \\
\text { (1976) }\end{array}$ \\
\hline & Wheat & 50 & $72 \%$ & 2153 & UK, Rothamsted & Prew and Dyke (1979) \\
\hline & Barley & 61 & $19 \%$ & 540 & UK, Rothamsted & Dyke and Slope (1978) \\
\hline Vetch & Barley & 30 & $23 \%$ & 550 & $\mathrm{CY}$, Athalassa & Papastylianou (2004) \\
\hline \multirow{2}{*}{$\begin{array}{l}\text { Grain } \\
\text { legumes } \\
\text { Oilseed } \\
\text { rape }\end{array}$} & $\begin{array}{l}\text { Durum } \\
\text { wheat }\end{array}$ & 80 & $1 \%$ & 72 & IT, Sicily & Giambalvo et al. (2004) \\
\hline & Wheat & $20-90$ & $9 \%$ & 490 & AT, Lower & Dachler and Köchl (2003) \\
\hline \multicolumn{7}{|c|}{ High fertilization (>100 kg N ha-1) } \\
\hline \multirow[t]{3}{*}{ Pea } & Wheat & 195 & $22 \%$ & 1608 & DE, Bavaria & Panse et al. (1994) \\
\hline & Wheat & $190-240$ & $22 \%$ & 1600 & UK, Rothamsted & McEwen et al. (1989) \\
\hline & Rye & $90-140$ & $5 \%$ & 500 & $\mathrm{CH}$, Changins & $\begin{array}{l}\text { Charles and Vuilloud } \\
\text { (2001) }\end{array}$ \\
\hline \multirow[t]{5}{*}{ Faba bean } & Barley & 122 & $14 \%$ & 425 & UK, Rothamsted & Dyke and Slope (1978) \\
\hline & Wheat & 195 & $23 \%$ & 1528 & DE, Bavaria & Panse et al. (1994) \\
\hline & Wheat & 150 & $5 \%$ & 275 & UK, Boxworth & $\begin{array}{l}\text { Bowerman and Clare } \\
\text { (1976) }\end{array}$ \\
\hline & Wheat & 170 & $2 \%$ & 153 & DE, Soest & $\begin{array}{l}\text { Luetke-Entrup et al. } \\
(2006)\end{array}$ \\
\hline & Wheat & $50-150$ & $63 \%$ & 1310 & ES, Andalucia & $\begin{array}{l}\text { López-Bellido and López- } \\
\text { Bellido } 2001\end{array}$ \\
\hline $\begin{array}{l}\text { Narrow- } \\
\text { leafed lupin }\end{array}$ & Wheat & 170 & $42 \%$ & 2753 & DE, Gülzow & $\begin{array}{l}\text { Luetke-Entrup et al. } \\
(2006)\end{array}$ \\
\hline Chickpea & Wheat & $50-150$ & $44 \%$ & 915 & ES, Andalucia & $\begin{array}{l}\text { López-Bellido and López- } \\
\text { Bellido } 2001\end{array}$ \\
\hline $\begin{array}{l}\text { Oilseed } \\
\text { rape }\end{array}$ & Wheat & $>100$ & $3 \%$ & 197 & AT, Lower & Dachler and Köchl (2003) \\
\hline
\end{tabular}

$4.3 \quad$ Nitrate leaching 
The nitrogen-rich nature of legumes and their residues has its drawbacks, including the potential for nitrate leaching and nitrous oxide emission. Leaching losses are influenced by a series of factors including the amount of available nitrate in soil, the volume of drainage water, soil texture and soil structure. To minimize losses, management aims to maximize the efficiency with which $\mathrm{N}$ mineralized in the soil or added in fertilizers is used by crops or retained in soils during drainage periods. In designing systems that produce grain legumes efficiently, it is important to consider both the effect of the individual species and the overall rotational system. A strong positive correlation was found between the proportion of pea in rotations and the concentration of nitrate in drainage and soil water (Beaudoin et al., 2005). This effect was also found by PlazaBonilla et al. (2015) where cumulative $\mathrm{N}$ leaching increased with the number of grain legumes in the rotation (from 1 to 3 crops) without cover crops. With cover crops, $\mathrm{N}$ leaching was reduced (Plaza-Bonilla et al., 2015).

The risk of nitrate leaching from intercrops is lower than from sole-crop grain legumes because of the uptake of mineral $\mathrm{N}$ by the non-legume component (Hauggard-Nielsen et al., 2003; Pappa et al., 2012; Mariotti et al., 2015). Deep-rooting legumes such as lupins can reduce leaching of nitrate by taking it up from deep soil layers (Dunbabin et al., 2003). In some low fertility environments such as in the Mediterranean region (Skoufogianni et al., 2013; Tosti et al., 2014) or organic systems (Möller et al., 2008), it may be advantageous to use grain legumes as cover crops to provide additional $\mathrm{N}$ to following crops, although there is a need to assess the associated financial costs and nitrate leaching risk. Mixtures of grain legumes with non-legumes are as effective as sole crops and more effective than bare fallow in preventing leaching, but more beneficial in providing $\mathrm{N}$ to the following crop (Tosti et al., 2014; Tribouillois et al., 2016). Triboulillois et al. (2016) suggested that the mixture can be designed to strike an appropriate balance between prevention of leaching and supplying $N$ to the following crop, depending on the fertility of the site and through-flow of drainage water.

The greatest risk of leaching loss from legume-supported rotations exists between the harvest of the legume and the main growth period of the following crop. The concentration of inorganic $\mathrm{N}$ is usually higher after a grain legume than after a cereal grown in the same conditions (Fustec et al., 2010). Residue quality is an important determinant of timing as well as quantity of $\mathrm{N}$ released into leachable forms, and is affected by the species (Kayser et al., 2010; Jeuffroy et al., 2013; Li et al., 2015), cultivar (Pappa et al., 2011) and management conditions (Jeuffroy et al., 2013). The incorporation of $\mathrm{N}$-rich legume residues compared to more $\mathrm{C}$-rich residues such as those of cereals causes different chronological patterns in microbial activity stimulated by the presence of easily decomposable materials (Carranca et al., 2009). Inorganic $\mathrm{N}$ left in the profile from the preceding crop and $\mathrm{N}$ mineralized from legume crop residues make an important contribution to the pre-crop effect. However, the amount of mineralized $N$ from crop residues that leaches 
depends on the balance between crop uptake and drainage through the soil profile, often referred to as a "lack of synchrony" between supply and demand. The amount of nitrogen left in the soil after harvest is greater after a sole crop than after an intercrop (Hauggaard-Nielsen et al., 2003; Schmidtke et al., 2004; Neumann et al., 2007; Pelzer et al., 2012), which is attributable to improved N scavenging by the cereal (Neumann et al., 2007). The relatively short growing period of spring-sown legumes in contrast to autumn-sown cereals can lead to longer uncropped periods and thus a higher risk of leaching than in many systems with winter cereals, especially before a subsequent spring sowing.

The risk of leaching after the harvest of grain legumes can be minimized by several strategies, including the use of catch and cover crops (e.g. Justus and Köpke, 1995; Möller and Reents, 2009; Tuulos et al. 2014), and prompt autumn sowing of crops such as oilseed rape after the legume to utilize $\mathrm{N}$ as it is released from residue of the previous crop. Catch crops can be stubble-seeded or under-sown in the grain legume crop, and take up nitrate and other nutrients until they are frost-killed or tilled. Utilising a catch crop before spring-sown grain legumes can reduce leaching loss compared with a winter sown grain legume (Nemecek et al., 2008). Losses from the following crop are likely to be lower if $\mathrm{N}$ fertilizer is reduced to compensate for $\mathrm{N}$ available from the legume residue. Because of the interactions between crops and cover crops, and the different management options that affect leaching, assessments should take the entire crop sequence into account. Reckling et al. (2016b) proposed a simple and static framework that supports such an assessment at the systems level. In five case studies across Europe, they found that when grain legumes were introduced into arable rotations, there was a minor difference in leaching ranging from -7 to $+1 \mathrm{~kg} \mathrm{ha}^{-1}$ on average compared to rotations without legumes (Reckling et al., 2016a).

\subsection{Nitrous oxide emissions}

Nitrous oxide $\left(\mathrm{N}_{2} \mathrm{O}\right)$ is a powerful greenhouse gas with an effect estimated at 265 times that of $\mathrm{CO}_{2}$ on a 100-year basis, and agriculture is a major source of anthropogenic $\mathrm{N}_{2} \mathrm{O}$ emissions (Myhre et al., 2013). The emission of $\mathrm{N}_{2} \mathrm{O}$ from arable crops depends on soil $\mathrm{N}$ status, applied $\mathrm{N}$ fertilizer or manure, and their interaction with crop management such as tillage and environmental factors (Henault et al., 2012; Rees et al., 2013). Soil type is also important as it is a major determinant of population compositions of denitrifying microbes (Graf et al., 2016). Losses occur both during the production of the crop and afterwards, the amount of the latter depending on residue management and whether the soil is left bare or a cover crop is sown.

Nitrous oxide emissions from grain legumes are generally lower than those from $\mathrm{N}$-fertilized crops and pastures (Rochette and Janzen, 2005; Dusenbury et al., 2008), with $\mathrm{N}_{2} \mathrm{O}-\mathrm{N}$ emission averaging $1.29 \mathrm{~kg} / \mathrm{ha}$ from legumes and $3.22 \mathrm{~kg}$ /ha from non-legumes (Jensen et al., 2012). 
Jeuffroy et al. (2013) found that legume crops in France emitted around five to seven times less GHG per unit area than other crops. Besides differences in rates of $\mathrm{N}$ inputs, climates, soils and management conditions, differences between legume species and even cultivars contribute to the variability (Pappa et al., 2011).

Nitrous oxide emissions may be higher in the period after harvest of the grain legume than during its growth. The $\mathrm{N}$-rich legume residues returned to the soil provide a readily available substrate for conversion to nitrous oxide as well as for leaching. The $\mathrm{N}_{2} \mathrm{O}$ emission resulting from the residues of grain legumes is sometimes similar to that of non-legumes (Pappa et al., 2011; Jeuffroy et al., 2013) and sometimes higher (Frimpong et al., 2011), illustrating the importance of measuring emission over a whole rotation instead of just one year (Dusenbury et al., 2008; Reckling et al., 2016a). The key to reducing losses at this point in a rotation, as for prevention of leaching, is improved synchrony between crop demand and nitrogen supply, and catch or cover crops may be important. The choice of legume and the management of the residues from that crop have knock-on consequences for the $\mathrm{N}_{2} \mathrm{O}$ emissions from subsequent crops (Pappa et al., 2011; Jeuffroy et al., 2013).

Nitrification of ammonia released from fertilizer or from mineralization of organic compounds produces nitrate, which is a prerequisite for denitrification. Nitrate is converted to nitrite by nitrate reductases and the nitrite formed can undergo a variety of reactions, of which conversion to nitric oxide (NO) by nitrite reductases (encoded by nir genes), is the best known and probably occurs most frequently in arable soils (Canfield et al., 2010). Nitrous oxide reductase (norB) reduces the $\mathrm{NO}$ further to $\mathrm{N}_{2} \mathrm{O}$, which is either released to the atmosphere or further reduced to $\mathrm{N}_{2}$ gas by nosZ-encoded enzymes. Some bacteria possess a full set of denitrification genes, whereas others only have some (Jones et al., 2014). A field test of nosZ-carrying Bradyrhizobium japonicum strains on soybean in Japan demonstrated the potential to reduce nitrous oxide emission in this way (Itakura et al., 2013).

\subsection{Agro-biodiversity and climate change adaptation}

Increasing grain legume production generally increases the diversity of crops in arable rotations in both temporal and spatial ways. This diversification affects the associated diversity of wild flora, fauna, and soil microbes (Collette et al., 2011) along with the weed-, pest- and diseaserelated issues that are a component of the break-crop effect described above. Where legumes are spring-sown, they have the potential to diversify winter-crop dominated arable systems: winter crops cover $59 \%$ of arable land in Germany and $62 \%$ in England and Wales, with proportions above $70 \%$ in some countries or regions (calculated from Statistik Austria, 2010, 
Defra and AHDB, 2012, Agreste, 2013 and Bundesministerium für Ernährung und Landwirtschaft, 2013).

Climate change provides an opportunity to develop the use of rarely grown crops, such as lentil in southern Germany (Gruber et al., 2012), chickpea in Central Europe (Neugschwandtner et al., 2014), narrow-leafed lupin in the Nordic region (Stoddard et al., 2009), and soybean in central Europe (Zimmer et al., 2016).

\subsection{Environmental effects in product life cycles}

Life-cycle assessment is a tool to examine the environmental impacts of a change by separating them into components and analysing them through an entire cycle of production and use.

Several LCA studies have analysed environmental impacts of the introduction of legumes into crop rotations. The main effects are:

- Reduction of $\mathrm{N}$ fertilizer use, due to minimal use of $\mathrm{N}$ fertilization in the legume crops and reduced fertilization of the following crop, so $\mathrm{N}$ emissions after fertilizer are reduced, in particular $\mathrm{N}_{2} \mathrm{O}, \mathrm{NH}_{3}, \mathrm{NO}_{3}$ and $\mathrm{NO}_{x}$. Furthermore, $\mathrm{N}$ fertilizer manufacturing is associated with consumption of fossil fuel and emission of GHGs, mainly $\mathrm{N}_{2} \mathrm{O}$ and $\mathrm{CO}_{2}$, and there are costs for transporting and spreading the fertilizer;

- Potentially increased leaching after legume crops (see 4.3), countering the abovementioned reductions of $\mathrm{N}$ use;

- Diversification of the crop rotation, which results in breaking pathogen cycles, potentially increased yields, possibly reduced pesticide inputs, and potentially higher associated biodiversity; and

- The environmental impacts of other feed compounds, feed additives, and feed transport, in studies at the level of livestock production.

The concrete effects depend on several factors such as the intensity of the production system (in particular the level of $\mathrm{N}$ fertilization and yields) and the diversity of the rotation. Nemecek et al. (2008) reported that pea grown in Germany had lower non-renewable energy requirements, GHG releases and eutrophication potential than cereals on a per hectare basis. The advantages were highest in crop rotations with high $\mathrm{N}$ input and a high share of cereals and less marked in diversified and less intensive ones. Adding pea to a non-legume rotation in three regions in France resulted in lower energy use and GHG releases (Nemecek et al., 2015). This advantage is eliminated when comparisons are made with 'non-legume' cropping systems designed to conserve resources, showing that the environmental and resource efficiency of the un-altered system is crucial to the outcome of increasing legume use. For example, Knudsen et al. (2014) showed that for rotations that used slurry as a major source of nutrients and for systems with no external inputs, faba bean resulted in higher GHG emissions per hectare than spring barley, 
whereas winter wheat had lower GHG emissions than the faba bean for the conventional and no inputs cropping at two of three locations. Thus, the results for cropping systems were greatly affected by the performance of the crop being replaced.

More examples are available from outside Europe. Incorporating narrow-leafed lupin in a two year cropping rotation in the semi-arid environment of Western Australia decreased measured GHG emissions from wheat production by $56 \%$ per hectare, and $35 \%$ per tonne of wheat, primarily by lowering nitrogen fertilizer inputs (Barton et al., 2014). Nevertheless, the profitability of the system with the legume was lower because of the narrow range of markets for the lupin crop. When pea or lentil replaced one of the spring wheat crops in an oilseed rape - spring wheat - spring wheat - spring wheat rotation, negative environmental impacts on global warming, resource use, ecosystem quality, and human health were all reduced and economic benefits accrued as a result of lower $\mathrm{N}$ fertilization and higher yields (MacWilliam et al., 2014). In southeastern Australia, total GHG emissions ( $\mathrm{CO}_{2}$-equivalent) were $225 \mathrm{~kg} \mathrm{t}^{-1}$ of grain for a $3 \mathrm{t} \mathrm{ha}^{-1}$ wheat crop following wheat, compared with 199 and $172 \mathrm{~kg} \mathrm{t}^{-1}$ following oilseed rape and pea, respectively (Brock et al., 2016).

In France, unfertilized intercrops of wheat and pea had a lower impact on climate change, acidification, terrestrial ecotoxicity, and cumulative energy demand than $\mathrm{N}$-fertilized sole crop wheat and unfertilized sole crop pea (Naudin et al., 2014). The results for the individual crops strongly depended on the allocation or system expansion method applied to handle the multifunctionality of the system.

As mentioned above, the diversification of the crop rotation leads to the expectation of lower toxicity potentials, but the high usage of biocides, especially insecticides, in conventional grain legume production (Kirkegaard et al., 2008) countered this benefit, such that the terrestrial ecotoxicity potential was not reduced (Nemecek et al., 2008 \& 2015). Cederberg and Flysjö (2004) calculated for an environmentally optimized pork production farm, that in total the application of biocides could be reduced by $58 \%$ per $\mathrm{kg}$ of pork, of which $10 \%$ was due to reduced soy imports and $48 \%$ was due partly to diversified crop rotation and partly to mechanical weed control instead of herbicides.

LCA of these changes in cropping system, like that of the use of grain legumes instead of imported soybean in feed chains, delivers equivocal answers because of the diversity of climates and cropping changes.

\subsection{Biodiversity}


Agricultural intensification in Europe over the last half century has led to biodiversity losses and population decline wild species associated with agricultural habitats (Donald et al., 2001; Benton et al., 2003). Spring sowing of legumes provides an opportunity for retaining crop stubble through winter before spring seeding. Over-wintered stubble provides combined forage and cover for small mammals, birds and insects that is not found in low-growing winter cereal crops (Potts, 2003; Evans et al., 2004; Gillings et al., 2005). In comparison to autumn-sown crops, springsown crops support greater abundance and diversity of weeds and arthropods, thereby providing more food to ground-foraging farmland birds (Berg et al., 2002; Dicks et al., 2013). Some of these effects may also apply to spring-sown grain legumes, but this depends on weed management. The introduction of even small areas of grain legumes into regions such as the Iberian peninsula could help the recovery of bird populations that have declined due to the simplification of farming landscapes (Cardador et al., 2015).

Legumes represent one of the highest quality foraging resources for pollinators (Jennersten, 1984; Decourtye et al., 2010). By providing nectar and pollen, the mass-flowering of grain legumes contributes to the maintenance of populations of wild and domesticated bees (Westphal et al. 2003). Faba bean flowers provide nectar to bumblebees with a long proboscis, such as Bombus hortorum L., B. pascuorum Scopoli and B. ruderatus Fabricius, and other large-bodied wild bees such as Eucera numida Lepeletier (Stoddard and Bond, 1987; Palmer et al., 2009). Faba bean and lupin flowers are important sources of pollen that honeybees (Apis mellifera L.) use for feeding the brood, although there is little or nectar in lupins and that of faba bean is out of reach of honeybees unless the flowers have been robbed by short-proboscis bumblebees (Green et al., 1980; Stoddard and Bond, 1987). Crop fields themselves are not suitable for ground-nesting wild bees, due to regular soil disturbance, application of biocides and the dense shading of the soil surface (Jeanneret et al., 2006).

Increases in population size and diversity of decomposer invertebrates such as earthworms and Collembola have been noted under perennial forage legumes (Eisenhauer et al., 2009, Sabais et al., 2011) but there is less information on the effects of grain legumes on them. Since soil disturbance reduces populations of many earthworm species, it is necessary to compare zerotillage systems with and without legumes in order to detect an effect of crop diversity on earthworm populations. One such study in the United States found substantially larger earthworm (Aporrectodea trapezoides Dugès) numbers in a no-till soybean-maize rotation than in the corresponding wheat-maize rotation (Hubbard et al., 1999), confirming that the effect on earthworms applies in annual as well as perennial cropping systems.

Below-ground biodiversity, including bacteria, archaea and fungi, provides ecosystem services such as nutrient cycling, biodiversity resources and water quality regulation (Mikkonen, 2012). 
Understanding how grain legumes influence soil microbial communities could help to understand and ultimately manipulate the break-crop effect. Pea monoculture in Alberta, Canada negatively affected a number of indicators of soil microbial function including microbial biomass carbon and bacterial diversity, in comparison with a wheat - wheat - pea rotation (Lupwayi et al., 2012). The lower microbial biomass may relate to the smaller return of residues from the grain legume compared to other crops in rotation. Scalise et al. (2015) observed shifts in bacterial community structure during legume-barley intercropping in southern Italy. The stimulated microbiota increased $\mathrm{N}$ cycling, leading to an increase in $\mathrm{N}$ release for the succeeding durum wheat crop, reducing the requirement for mineral $\mathrm{N}$ fertilizer.

Inoculation with rhizobium aimed at enhancing BNF may also influence yield and improve health of other crops in the rotation as a result of stimulating microbial diversity and activity. This has been observed in potato following rhizobial inoculation of preceding legume crops in Tunisia, although the effect was inoculum specific (Trabelsi et al., 2012). Incorporated legume crop residues influence the microbial community in following crops, and the effect is speciesdependent. Lupwayi and Soon (2016) found greater increases in soil microbial carbon and $\beta$ glucosidase activity from faba bean than from pea in Alberta. They also observed differences up to 3 years after the incorporation of legume residues indicating the importance of looking for precrop effects across the whole rotation.

Research comparing the impact of grain legumes with cereals on soil bacterial communities suggests that soil type, environment (Scalise et al., 2015) and management (Tautges et al., 2016) may have more impact than crop type. A meta-analysis showed a clear effect of crop diversity on both microbial richness and diversity, but there was no consistent effect of legumes on either of these parameters (Venter et al., 2016).

\section{Status of legumes in Europe}

\subsection{Changes in EU production of grain legumes over time}

The area of grain legumes in Europe declined almost continuously over the last five decades, from 5.8 million ha in 1961 (4.7\% of the arable area) when recording began to 2.0 million ha in 2014 (1.6\% of the arable area) (FAOstat, 2016). A major underlying driver behind the reduction in the proportion of arable land used for legume crops is the increased comparative advantage in the production of starch-rich cereals in Europe over the production of protein-rich grain legumes. Between the 1970s and the 1990s, wheat yields in north-western Europe increased annually by about 0.15 t/ha (Supit, 1997). Expansion of wheat production in Europe has been facilitated by the availability of nitrogen fertilizers, genetic improvement, irrigation and pesticides (Gervois et 
al., 2008). Wheat yields have risen markedly in Europe over the last 50 years, as shown by French wheat (Figure 2). Yields of protein crops, exemplified by French pea, lag a long way behind, so these crops have become increasingly unattractive to the farmer. In the USA, however, yields of small-grain cereals and protein crops have remained similar. Pea yields have shown an overall decline in France in recent years as the increased frequency of production in the rotation led to disease and a consequent shift of production to poorer soils and associated lower yields (Magrini et al., 2016). The comparative advantage of using European land to grow wheat instead of protein crops has thus steadily increased. Specialization and intensification effects have resulted in the development of more concentrated production and more specialized farming systems in Europe during this period (Brouwer, 2006). The production of grain legumes is unevenly distributed across Europe (Figure 3 ) and many areas that have a large number of livestock farms have low areas of grain legume production because they are unsuited to arable agriculture. The combination of availability and low costs of synthetic nitrogen fertilizers relative to farm product prices (e.g. cereals, milk, beef) and imported protein feed has been another major enabler of this process. However, as fertilizer prices rise relative to product prices, farmers will use less fertilizer (Piesse and Thirtle, 2009), possibly encouraging legume production.

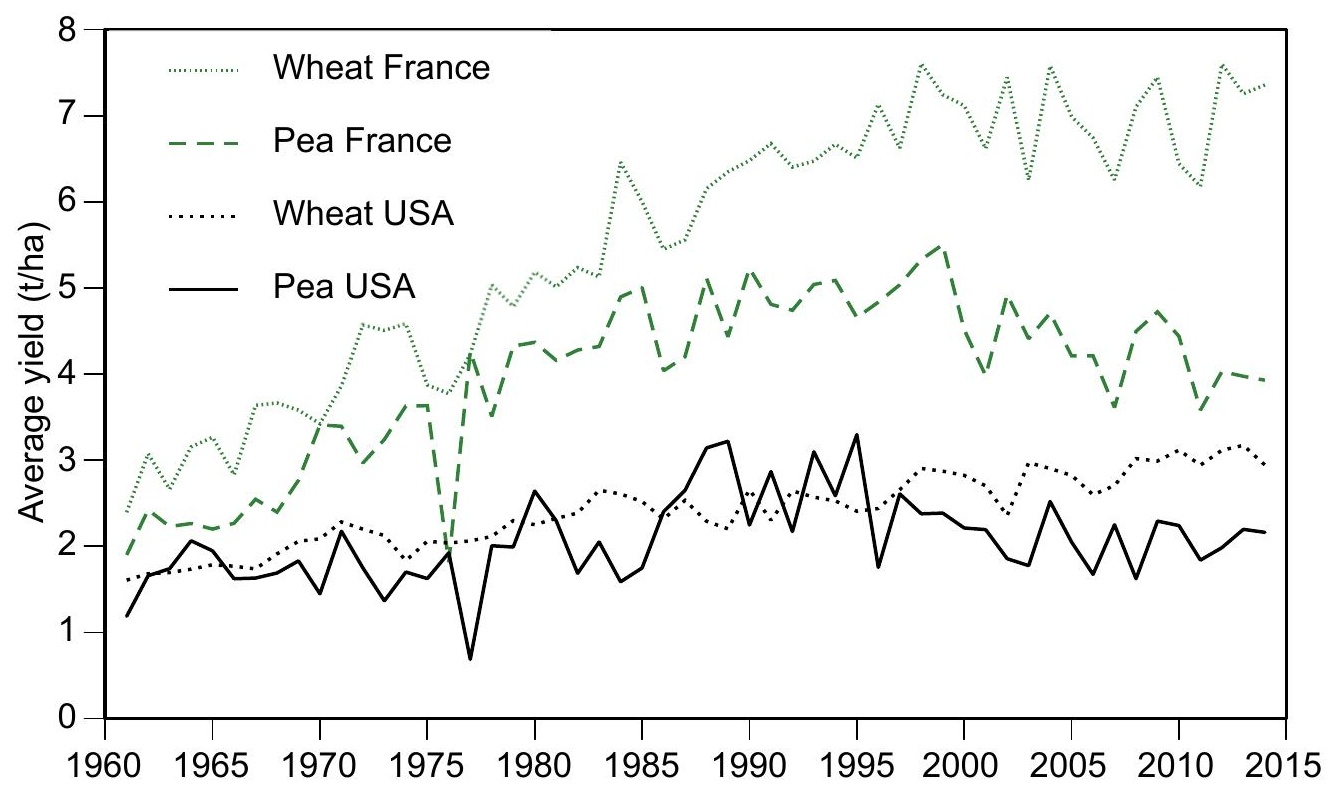

Figure 2 Yields of wheat and pea in the USA and France (1961-2014). Data from FAOstat (2016). 


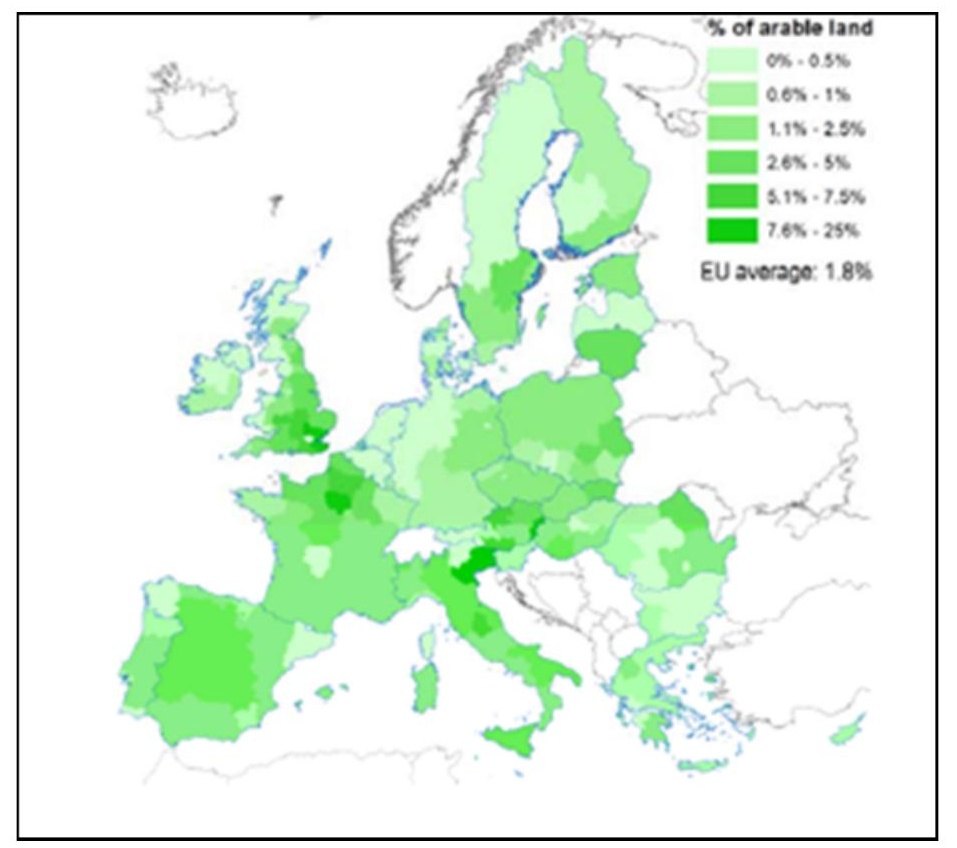

Figure 3 Proportion of EU-27 arable land used for protein crops in 2010 (\%) Source: Calculations based on data from Eurostat (2013).

The area and quantity of grain legumes grown in the EU-27 countries are shown in Figure 4, which also shows the introduction $(1974,1978,1989)$ of various policy support measures in Europe, along with the reduction (1992) and removal (2005-2006) of direct support. This illustrates the lack of success of those support mechanisms in significantly increasing the land area under grain legume production. It is only for faba bean, soybean and pea that an increase in the production area can be observed due to legume production moving to more fertile soils and more intensive management, (Fig. 4B). However, the production of grain legumes in Europe has increased by nearly $70 \%$ in 2015 to 2.7 million ha (Eurostat, 2016). The use of grain legumes in organic cropping systems (12\% of the organic arable area) accounts for about $12 \%$ of the total grain legume area (estimated from European Commission, 2013). From these estimates it seems that the decline in production has stopped. The increase in 2015 was highest in countries with higher coupled payments (e.g. Poland), but it was also recorded in other countries (e.g. Germany, UK). The grain legume area in Germany increased from 75 thousand ha in 2013 to 188 thousand ha in 2016 (DESTATIS, 2016). It is clear from the European Commission's review of Greening (European Commission, 2016) that the use of nitrogen-fixing crops (i.e., legumes) to fulfil the ecological focus area has accounted for a significant proportion of the expansion. 


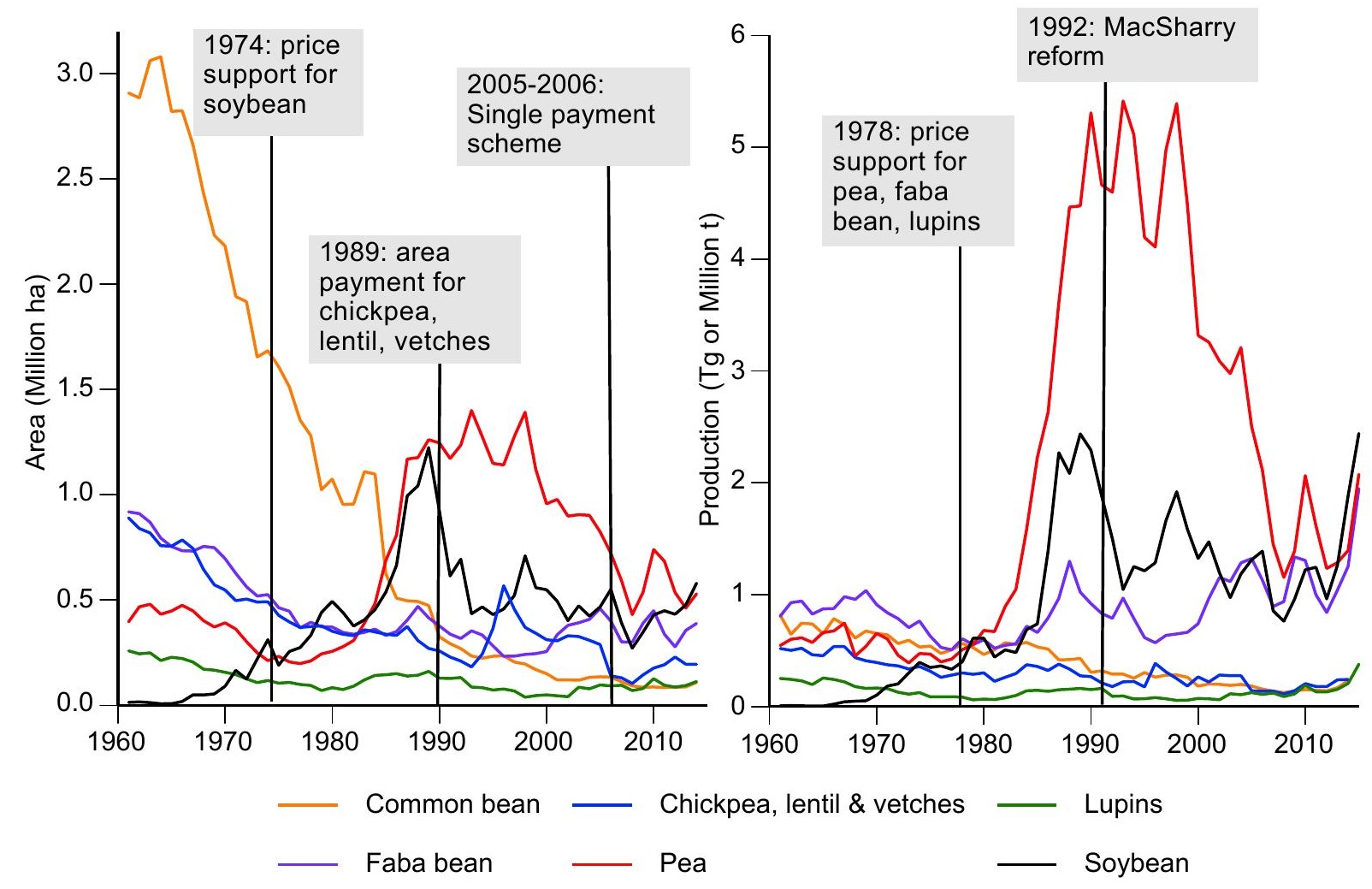

Figure 4. A, Production areas and B, production quantities of grain legume crops in the EU-27 countries (1961-2015). Data from FAOstat (common bean, chickpea, lentil and vetches) and Eurostat (all others), 2016.

While the legume cropped area declined, the proportion destined for food use reduced. In 1961, grain legume production in Europe was dominated (67\% total area) by production for human consumption (exclusive food pulses: chickpea, cowpea (Vigna unguiculata (L.) Walp.), groundnut (Arachis hypogaea L.), lentil, and common bean). This dropped to $27 \%$ of the area by 2013 (FAOstat 2016). Currently, $11-15 \%$ of pea and $9-14 \%$ of faba bean produced are used for human consumption (PROLEA 2011), and only $43 \%$ of the food legumes consumed in Europe are produced within the EU (FAOstat 2016). Pea and soybean for animal feed became the two most widely grown protein crops in the 1980s following the introduction of policy support for protein feed crops, but pea production fell again two decades later (Figure 4B).

\subsection{Lessons for European producers from other developed regions}

In order to see what can be achieved with legumes in developed countries, we will consider two contrasting cases, Australia and Canada, where grain legumes have in many recent years exceeded $10 \%$ of the arable land sown to annual crops. Australia provides a model for southern Europe, and Canada for northern.

In the arable zone of southern Australia, until the 1970s, the primary "rotation" was wheat sheep, with the livestock grazing the stubble and whatever pasture grew or was sown in the 
fallow year. From the 1930s, subterranean clover (Trifolium subterraneum L.) and annual medics (Medicago spp.) were increasingly widely sown, often established by undersowing the wheat, thus providing a managed pasture for grazing after harvesting the cereal. When the price of both wheat and wool dropped, diversification was necessary. In Western Australia, lupins were seen as suitable crops for the prevailing acid, sandy soils already in the early 1900s, and John Gladstones led the domestication of narrow-leafed lupin from the late 1950s. From 1992 to 2002, narrow-leafed lupin was annually harvested from over 1 million ha (Figure $5 \mathrm{~A}$ ), but then areas fell, partly because the rotation (wheat - narrow-leafed lupin) was too narrow and the combination of low feed prices, soil acidification and the development of herbicide-resistant ryegrass led to the need for new management methods. New cultivars with resistance to other classes of herbicides are expected to restore the area of the crop. The primary market for lupin grains is as a feed supplement for ruminants, with some use for monogastrics and a little for fish. Flour, protein and fibre extracts are used as food supplements, and various positive effects on consumer health have been shown for the human consumer (Johnson et al., 2006; Lee et al., 2009), but market diversification is needed.

In south-eastern Australia, soils were found to be more suitable for starchy legumes. Both faba bean and pea arrived with the first European settlers in 1788 (Worgan, 1788). By the 1960s, dry pea was grown on $20000-25000$ ha, and its area hit 300000 ha in 1986 (Figure 5A). Faba bean areas first exceeded 10000 ha in 1976 and 100000 ha in 1997, while lentil reached the same thresholds in 1996 and 2004, and chickpea in 1983 and 1990. The food-quality, export market is vital for the market value of these crops, with the high value of chickpea crops helping to compensate for their yield variability (Schilizzi and Kingwell, 1999). Crop breeding programmes were initially scattered across the relevant states, but during the 1990s, they were reorganized, mostly into a single centre for each crop (e.g., Adelaide, South Australia for faba bean in the winter-rainfall zone) with 1-2 "nodes" for different climatic zones (Narrabri, New South Wales for faba bean in the summer-rainfall zone). In this way, the application of breeding technologies was focused, while selection for adaptation to the major climatic zones, with their different disease and stress pressures, was separated. Diversification of Australian cropping systems is seen as helping to protect the farmer against swings in commodity prices (Connor, 2004).

In Canada, the portfolio of legume species is different. Initially, soybean was restricted to southern parts of the province of Ontario, but since 2000 up to a third of the crop has been harvested from other provinces, as cultivars have been developed with earlier maturity and adaptation to longer photoperiods. Common bean is also sown in the southern parts of the country. Breeding programmes for the food legumes pea, lentil and chickpea were established at the University of Saskatchewan in the late 1970s and 1980s and became highly successful, with 
most of the world's trade in lentil and pea (Zentner et al., 2002) being based on Saskatchewan produce. In 2015, $10 \%$ of the arable area of the province of Saskatchewan was sown to lentil and another $10 \%$ to other grain legumes (A. Vandenberg, pers. comm., June 2015). Production of lentil has exceeded 1 million t most years since 2004, and pea has exceeded that value since 1994 (Figure 5B). Clearly, the crops are highly successful, and important in the crop rotations of the prairie provinces. The breeding programmes release cultivars for various market classes of size, colour and composition, in addition to adaptation to different lengths of growing season and soil types. The main target is food use with its high value, and only material rejected from the food sector is relegated to the feed chain.

Both of these cases have used a combination of feed (soybean and lupin) and food (lentil and chickpea in particular) crops, and provide materials for export as well as home use. Public-sector investment in pulse breeding has been supported by small levies on production, leading to continuous breeding improvements in yield, quality and resistance to biotic and abiotic stresses. Perhaps Europe's policy-makers can learn from this.
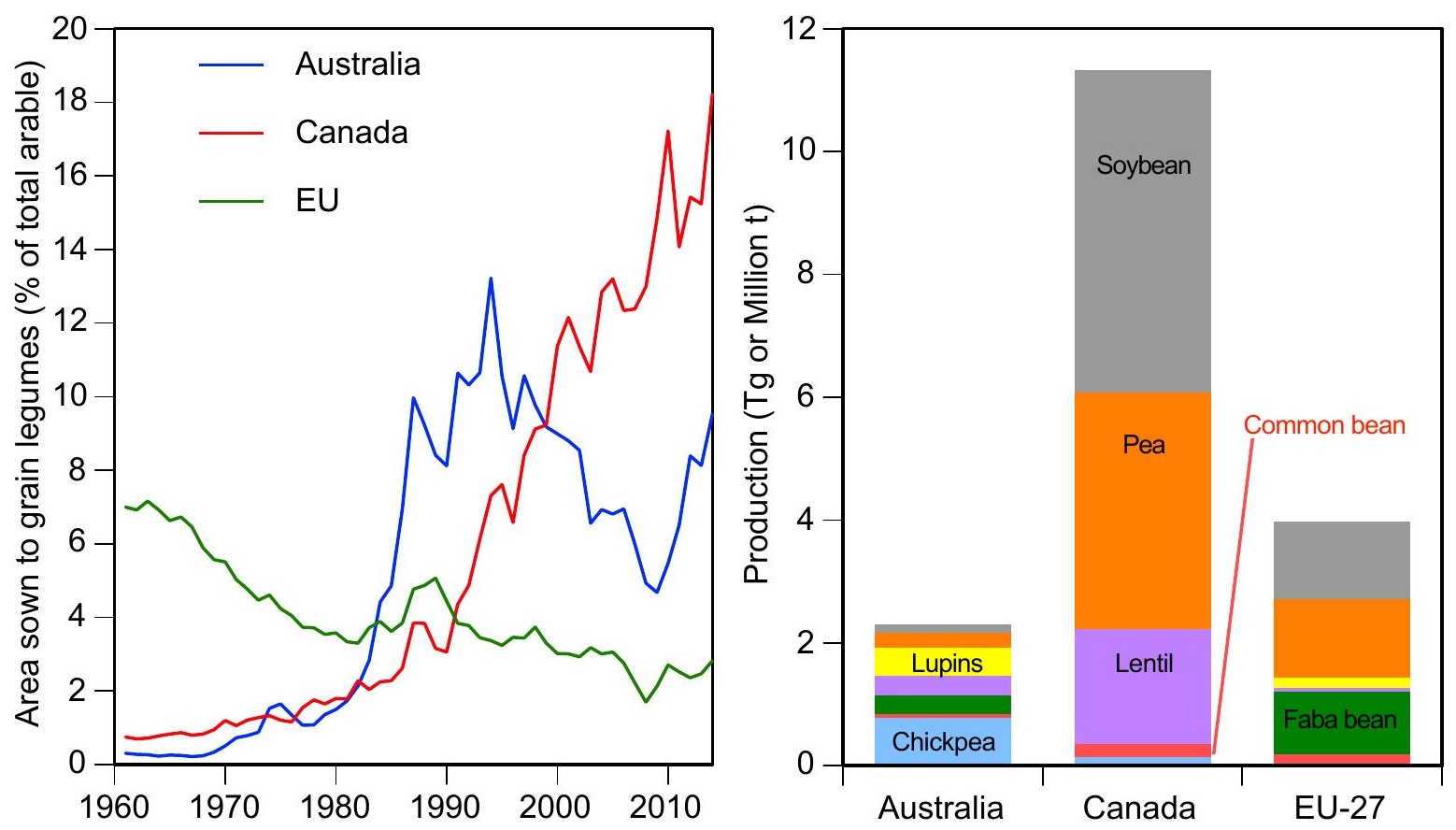

Figure 5. A. Areas sown to the major grain legumes (chickpea, common bean, faba bean, lentil, lupins, pea and soybean) as a percentage of total arable area (cereals, grain legumes, oilseeds, fibre crops, and root and tuber crops) for the EU-27, Australia and Canada from 1961 to 2015. B. Production of the major grain legumes in Australia, Canada and the EU-27 in 2013. Data from FAOstat (2016) and Eurostat (2016). 


\section{Developing legume production systems for Europe}

Grain legumes can be produced as dry grain, green forage, silage, or green manure depending on the pedo-climatic conditions and farming system. In some parts of Europe where winters are not severe, autumn-sown grain legumes can be grown. In Mediterranean regions, grain legumes such as pea are grown as a cool-season crop harvested before summer drought or before planting an irrigated, warm-season crop such as maize. Grain legumes have generally been produced as sole crops, but there has been a resurgence of interest in intercropping (Malézieux et al., 2009). Cereal-legume intercrops can be used for forage or grain depending on growing conditions and farm management, and using them for whole crop silage is a way of boosting the forage protein content of livestock diets (Anil et al., 1998). In a recent study (Bedoussac et al., 2015), cereal-legume intercrops had a higher and more stable gross margin than the mean of partner crops grown as sole crops (702 versus $577 € / \mathrm{ha}$ ) under the same conditions. There is also some interest in intercropping legumes with oil crops, such as pea with linseed (Linum usitatissimum L.) (Zajac et al., 2013) or faba bean with either safflower (Carthamus tinctorius L.) or mustard (Sinapis alba L.) (Schröder and Köpke, 2012).

Mixing cultivars in the same field can also have advantages such as increased yield stability and disease management (Wolfe, 1985). In China, natural enemies have been shown to increase in soybean production by mixing cultivars, which means that the mixtures provide pest control benefits compared with the production of a single cultivar (Pan and Qin, 2014). Faba bean cultivars are often composed of 2-3 inbred lines that are allowed to cross-pollinate for 2-3 generations during the multiplication of seed, thus gaining some hybrid vigour as well as presenting heterogeneity to pests and pathogens (Link, 2006).

\subsection{Yield stability in grain legumes}

Grain legume yields are considered to be more variable than those of cereals, and yield fluctuations are one of the main reasons farmers give for not growing these crops (von Richthofen et al., 2006a). However, little and contradictory quantitative evidence is available on yield stability in grain legumes. Some statistical analyses suggest that the yield stability of grain legumes is higher than that of other crops (Schäfer, 2003; Peltonen-Sainio and Niemi, 2012), whereas others indicate the lowest yield stability for grain legumes across Europe and the Americas (Cernay et al., 2015). In a set of 14 studies, pea was the most variable in 4 , lupin in 4 , rapeseed in 4, and small-grain cereals in two (Table 3), indicating that broad-leaved crops indeed have more unstable yields than cereals. However, statistical analyses of yield stability using the coefficient of variation have several weaknesses. Few of the available datasets are spatially explicit, and grain legumes that are often grown on less productive soils were compared 
with crops grown on all types of soils, which would negatively influence yield variation statistics. Hence, other stability parameters are needed (Döring et al., 2015).

Analysis of grain legume yield stability under the same soil and management conditions is required, e.g., using long-term cropping system experiments across a wide range of soil types. Such analyses are still rare. The yield stability of narrow-leafed lupin and pea in an organic monitoring experiment in northeastern Germany was higher than that of maize and cereals (Reckling et al., 2015). Other reasons for yield instability in grain legumes include their indeterminate growth habit, allowing them to respond to good conditions, and the relative lack of investment in breeding for stress resistance, allowing the crop to fail in poor conditions (Stoddard et al., 2009). The stress tolerance of the rhizobium symbiont often does not match that of the legume host, adding to the depression of plant growth in poor conditions (Zahran, 1999). Strategies regarding breeding and agronomic techniques need to be developed to reduce yield variability. 
Table 3. Coefficient of variation (\%) of grain legume yields compared to other crop species

\begin{tabular}{|c|c|c|c|c|c|c|c|c|c|c|c|c|c|c|}
\hline Source and details & Site & Pea & Faba bean & Lupin & $\begin{array}{r}\text { Commo } \\
\mathrm{n} \text { bean }\end{array}$ & Soybean & Vetch & Chickpea & Rapeseed & Wheat & Maize & Rye & Oat & Barley \\
\hline $\begin{array}{l}\text { Reckling et al. (2015), } \\
\text { data set } 1\end{array}$ & Germany & & & 46 & & & & & & 33 & 14 & 31 & & \\
\hline $\begin{array}{l}\text { Reckling et al. (2015), } \\
\text { data set } 2\end{array}$ & Germany & 83 & & & & & & & & 29 & 44 & 18 & 43 & \\
\hline \multirow{2}{*}{$\begin{array}{l}\text { Schäfer (2003), } 20 \text { yrs } \\
\text { national yield data }\end{array}$} & Germany & 9.4 & 10 & & & & & & 13.8 & 6.9 & & 14.4 & & 8.5 \\
\hline & Denmark & 9 & & & & & & & 11.6 & 3.8 & & & & \\
\hline \multirow{5}{*}{$\begin{array}{l}\text { Peltonen-Sainio and } \\
\text { Niemi (2012), National } \\
\text { yield (5-yr moving } \\
\text { average), 1997-2007 }\end{array}$} & Finland & 17.4 & & & & & & & 12.5 & 13.7 & & & & \\
\hline & France & 10.3 & & & & & & & 10.2 & 6.8 & & & & \\
\hline & Germany & 11.5 & & & & & & & 12.7 & 6.8 & & & & \\
\hline & Spain & 17.5 & & & & & & & 21.6 & 19 & & & & \\
\hline & Sweden & 10.2 & & & & & & & 8.4 & 4.7 & & & & \\
\hline \multirow[t]{2}{*}{$\begin{array}{l}\text { Peltonen-Sainio and } \\
\text { Niemi (2012), Southern } \\
\text { Finland, 2000-2011 }\end{array}$} & Finland & 7 & 7 & & & & & & 13 & & & & & 5 \\
\hline & $\begin{array}{l}\text { Eastern } \\
\text { Europe }\end{array}$ & 17 & & 23 & 17 & 14 & 20 & & & 11 & & 9 & 9 & 12 \\
\hline \multirow{3}{*}{$\begin{array}{l}\text { Adapted from Cernay et } \\
\text { al. }(2015)^{b}\end{array}$} & $\begin{array}{l}\text { Northern } \\
\text { Europe }\end{array}$ & 11 & 15 & 39 & 20 & & 16 & & 7 & 6 & & & 8 & 7 \\
\hline & $\begin{array}{l}\text { Southern } \\
\text { Europe }\end{array}$ & & 8 & & 11 & 13 & 12 & 17 & & 7 & 8 & & 11 & 16 \\
\hline & $\begin{array}{l}\text { Western } \\
\text { Europe }\end{array}$ & 9 & 10 & 28 & 11 & 11 & & & 8 & 6 & 8 & 10 & & 6 \\
\hline
\end{tabular}

a The coefficient of variation is defined as the standard deviation divided by the arithmetic mean; values in bold are those with the highest yield variation in the row

b Data shown for local polynomial ('loess') regression method; other data not shown: Potato $8 \%$ in Eastern Europe, and $7 \%$ in Northern Europe, sunflower $13 \%$ in Southern Europe 


\subsection{Yield and quality in crop mixtures}

Yields of cereal-legume intercrops vary depending on species and cultivar of both components (Rauber et al., 2001; Lauk and Lauk, 2008; Lithourgidis et al., 2011), cereal to legume ratio (Hauggaard-Nielsen et al., 2003, 2006, 2008, 2009; Micek et al., 2012) and growing conditions (Hauggaard-Nielsen et al., 2009). The yield advantage of intercrops or crop mixtures is generally attributed to complementarity of resource interception and use, but may also result from interspecific facilitation or the positive influence of one species on another (Willey, 1979; Vandermeer, 1989; Malézieux et al., 2009; Brooker et al., 2015). The effect of intercropping is often measured by the Land Equivalent Ratio (LER), which compares the yield of the intercrop with that of the pure crops (Mead and Willey, 1980). A value above 1 indicates that the total yield of the intercrop is higher than the average yield of the components grown separately. Most published studies on intercropping focus on aboveground interactions, although changes in microbial biomass size and activity and bacterial diversity have also been found (Saini et al., 2004; Lupwayi and Kennedy, 2007; Song et al., 2007). For success, crop mixtures require complementarity rather than competition in resource interception, and the different above-ground and below-ground architectures and physiologies of cereals and grain legumes are often well suited in this way.

The advantage of cereal - legume mixtures over pure cereals is generally greater in systems with little or no usage of nitrogen fertilizer (Jensen, 1996; Ghaley et al., 2005) and agrochemicals (Szumigalski and Van Acker, 2005). A meta-analysis of the effect of $\mathrm{N}$ fertilizer on production in grain legume - cereal intercrops showed that it decreased the proportion of grain legume in the mixture without significantly affecting LER (Pelzer et al., 2014). Weed suppression in cereal - legume intercrops often exceeds that of sole crops, with examples from barley - pea (Corre-Hellou et al., 2011), winter wheat - faba bean (Bulson et al., 1990; Haymes and Lee, 1999), winter wheat - pea (Paolini et al., 1993), and maize - common bean (Bilalis et al., 2010). This reflects the increased resource use of intercrops, particularly light interception (Liebman and Robichaux, 1990; Corre-Hellou et al., 2011), and is shown in terms of reduced total weed biomass, weed species richness and relative abundance of dominant weeds (Poggio, 2005). Chemical weed control is difficult or impossible in intercrops, as few herbicides are tolerated by both a cereal and a legume.

In 58 field experiments conducted in France and Denmark since 2001 where either no fertilizer or organic fertilizer was applied, intercropping led to higher and more stable grain yield than the mean of the corresponding sole crops (3.3 versus $2.7 \mathrm{t} / \mathrm{ha}$ ) (Bedoussac et al., 2015). Intercrops usually yield more than sole-crop legumes (Pelzer et al., 2012), and often more than sole-crop cereals (e.g. Jensen 1996; Hauggaard-Nielsen et al., 2001; Hauggaard- 
Nielsen et al., 2003; Andersen et al., 2004; Naudin et al., 2010), but not always (HauggaardNielsen et al., 2006; Pelzer et al., 2012; Neugschwandtner and Kaul, 2014). The proportion of legume and non-legumes in the mixture influences both yield and $\mathrm{N}$ offtake, and increased yield has frequently been observed with higher total seed density of mixtures compared to sole crops, such as $100 \%+50 \%$ (faba bean and wheat, Bulson et al., 1997; pea and oat, Neumann et al., 2007 and 2009). The proportions of crops in the mixture can be adjusted for maximum yield according to the site and environmental conditions that influence competition (Neumann et al., 2009). In intercrops used for forage, the crude protein yield can be greater than in sole-cropped legumes, for example, a faba bean - triticale mixture yielded $12 \%$ more protein than faba bean alone (Dordas and Lithourgidis, 2011).

Cereal protein concentration was higher in unfertilized intercrops than in sole crops (11.1 versus $9.8 \%$ ) (Bedoussac et al. 2015). Intercropping with grain legumes increased the $N$ concentration of wheat by $8 \%$ on average across a range of European sites managed organically and in some cases also increased its $S$ concentration by $4 \%$ on average across the same range of sites (Gooding et al., 2007). Neumann et al. (2007) found grain nitrogen content of both oats and peas were greater in mixtures than in sole crops. Lodging of peas can limit their yield (Annicchiarico and lannucci, 2008), partly due to loss of harvestable yield and partly to reduced light penetration reducing pod formation (Schouls and Langelaan, 1994), but the cereal in an intercrop provides physical support that reduces this lodging (Podgorska-Lesiak and Sobkowicz, 2013).

Nutrition is another factor affecting the success of legume - cereal intercropping. The cereals are generally better than legumes at taking up mineral $\mathrm{N}$, leaving the legume to rely on BNF, as discussed earlier. Legume root exudates liberate phosphate and several cation species, and the cereal roots liberate other nutrients, leading to increases in the $\mathrm{P}$ uptake of cereals and Fe and Zn uptake of legumes compared to sole crops (Li et al., 2007; Zuo and Zhang, 2009; Xue et al., 2016).

\subsection{Crop protection (weeds, pest and diseases)}

Due to pest and disease constraints and subsequent declines in crop yield and soil function, grain legumes are grown within rotations rather than in consecutive years. A critical component of rotation design is the use of crops with different life cycles and growth habits for control of weeds, pests and diseases (Garrison et al., 2014; Cook, 2003). The frequency of legumes within a rotation is likely to be determined by the longevity of survival of their 
pathogens. Too frequent inclusion of grain legumes in the rotation reduces their yields (Pfender \& Hagedorn, 1983).

Grain legumes suffer from a wide range of diseases and pests. The cool-season pulses, namely chickpea, faba bean, lentil and pea, are closely related and have closely related pathogens. Each is host to a cool-weather blight fungus in genus Ascochyta that spreads primarily by rain-splash and is potentially seed-borne. Pea hosts two additional fungi in its disease described as "ascochyta complex", Mycosphaerella pinodes (Berk. \& A. Bloxam) Vestergr. and Phoma medicaginis var. pinodella Malbr. and Roum. Botrytis cinerea Pers., grey mold of chickpea and lentil, and $B$. fabae Sard., chocolate spot of faba bean, flourish when surfaces remain moist at temperatures near $20^{\circ} \mathrm{C}$ and can cause complete crop loss. Each of the cool-season pulses hosts a rust in genus Uromyces that is more prevalent in warmer weather conditions than the other two genera. The warm-season legumes also host rust diseases, Uromyces spp. on common bean and Phakospora spp. on soybean. Plant breeders have made progress in identifying sources of resistance to most of these leaf and stem diseases, but not to those of roots and crowns, where the most challenging is root rot of pea, caused by the oomycete Aphanomyces euteiches Drechsler that can remain viable in the soil for up to 9 years after a pea crop (Gaulin et al., 2007; Rubiales et al., 2015). A key part of integrated management of these diseases is to ensure that successive legume crops in rotations are sufficiently far apart in time that the inoculum has reduced and far apart in space that residues cannot spread infection (Stoddard et al., 2010). Generalist pathogenic fungi such as Sclerotinia sclerotiorum, Fusarium spp. and Verticillium spp. attack grain legumes when conditions are favourable. The warm-season legumes are subject to bacterial blights, whereas these are seldom found on cool-season legumes. Another problematic fungus is Colletotrichum lupini (Bondar) Nirenberg, Feiler \& Hagedorn, the causal agent of anthracnose. In Germany, narrow-leafed lupin largely displaced white and yellow lupins in the 1990 s because of its higher tolerance to the this fungus.

The main insect pests of grain legumes are aphids, bruchid beetles, leaf weevils and moths. Of the aphids, Aphis fabae Scopoli, A. glycines Matsumura and Acyrthosiphon pisum Harris are particularly widespread and spread many viruses, so control is vital (Stoddard et al., 2010, Rubiales et al., 2015). Furthermore, A. fabae has a wide host range of over 200 species. Larvae of several bruchid species develop within growing seeds of the grain legumes, so they are shielded from many insecticides, and their damage greatly reduces the quality of the crop for both seed and food uses (Keneni et al., 2011). Leaf weevils in genus Sitona do damage to the plant in two ways: the adults cut distinctive, semi-circular notches in 
the leaves and the larvae eat the root nodules, so even low rates of infestation reduce yield (Lohaus and Vidal, 2010) and pNdfa (Corre-Hellou and Crozat, 2005). The larvae of the pea moth, Cydia nigricana Fabricius, consume many grain legumes including faba bean, lentil and narrow-leafed lupin, but the egg-laying females are most strongly attracted by pea (Thörning et al., 2014). Seeds that are only partly damaged by the larvae are not easily separated from undamaged seeds during processing, reducing value for seed and food uses.

Weed control is seen as a major challenge for grain legume production due to their generally open growth habit and slow initial growth rate, compared to cereals. Increased crop density often helps to control weeds (vining pea, Lawson and Topham, 1984; faba bean, McEwen et al., 1988), but increases seeding costs, lodging due to the weaker stems of the crowded plants, and the spread of diseases. In both faba bean and chickpea, combinations of row spacing and mechanical control were competitive with herbicides, but in field pea some herbicide was still needed in combination with these other methods (Avola et al., 2008). The use of cultivars that are competitive against weeds is another important strategy for optimising grain legume production, especially in systems where herbicides are avoided. The improved standing power of semi-leafless pea over conventional-leafed pea comes at the cost of weed suppression in pure stands (Spies et al., 2011) and in organic crop mixtures with oat (Gronle et al., 2015).

Some legumes are affected by parasitic weeds, of which the broomrapes are the most economically damaging (Rubiales and Fernández-Aparicio, 2012). Crenate broomrape (Orobanche crenata Forsk) is widely distributed in the Mediterranean basin and attacks most grain legumes (Rubiales et al., 2009). The major control strategies currently available to farmers are the use of resistant cultivars and chemical control, along with appropriate rotations (Rubiales and Fernández-Aparicio, 2012). Intercropping with oat reduces the parasitism of faba bean and pea, possibly due to allelochemicals from the oat roots (Fernández-Aparicio et al., 2007).

\subsection{Soil management, organic matter and soil structure}

Legumes have the potential to improve soil structure, water holding capacity, increase soil organic carbon (SOC) (Leithold et al., 1997; Jensen et al., 2012), and reduce soil compaction. This effect results from the strong tap-root and thick lateral roots of grain legumes, brassicas and other broad leaved crops that contrast with the fine roots of the small-grain cereals. When the roots die and decay, they provide a continuous network of 
residual root channels and macropores in the subsoil, penetrating soil hardpans (especially by species with a vigorous tap-root such as faba bean) (Rochester et al. 2001, Jensen and Hauggaard-Nielsen 2003). This enhances soil permeability and hence both water infiltration into the soil (McCallum et al., 2004) and the deep growth of the roots of the following crop (Kautz et al., 2013). Optimising production in cropping systems requires good soil structure, and pea and faba bean have been shown to be more sensitive than cereals to compaction (Lipiec and Samota, 1994; Arvidsson and Håkansson, 2014), while narrow-leafed lupin may be more tolerant than barley (Trükmann et al., 2008). Bengough and Young (1993) showed that pea root elongation was reduced as bulk density and penetration resistance increased. There are cultivar as well as species differences in sensitivity to compaction (Vocanson et al., 2006). Grain legumes contribute organic matter to soil via inputs of organic residues during growth (rhizodeposition), root turnover and nodule turnover as well as through residue incorporation.

The quantity of residues from a grain legume is likely to be less than that from a cereal as a result of lower production of both above- and below-ground biomass although comparative estimates of above and belowground biomass are hard to find.the European literature. The impact on soil organic carbon is affected by residue quality as well as quantity and legume residues generally have lower C:N ratios than non-legumes (Meyer-Aurich et al., 2006; Begum et al., 2014; Laudicina et al., 2014; Jensen et al., 2012; Sanz-Cobena et al., 2014; Tosti et al., 2014), although this varies with species and cultivar (Jeuffroy et al., 2013; Schwenke et al., 2015). In combination with their generally lower lignin content (Laudicina et al., 2014) than cereal roots, this results in more rapid decomposition.

The rapid decomposition of legume residues has important implications for designing rotations and optimising systems with grain legumes. The rotational and break-crop effects of introducing a wider variety of crops into cropping systems noted above (Section 3.3) have the potential to increase crop yield leading to increased residue biomass and hence soil carbon input (West and Post, 1992; Drury and Tan, 1995). The difference depends not only on the above- and below-ground properties of the introduced crop but also on the nature of the monoculture comparator. In a meta-analysis, mixed rotations were found to increase soil carbon by $11 \%$ compared to continuous soybean but by only $2.9 \%$ compared to continuous wheat (McDaniel et al., 2014). Introducing soybean into continuous maize caused a decrease in soil organic carbon (SOC) on account of the lower biomass and $\mathrm{C}: \mathrm{N}$ ratio of the legume (Meyer-Aurich et al., 2006). Similarly, SOC accumulation was lower under wheat/faba bean rotations (3.6 $\mathrm{t} \mathrm{ha}^{-1}$ over 19 years) than in wheat monoculture $\left(5.6 \mathrm{t} \mathrm{ha}{ }^{-1}\right.$ 
over 19 years) (Laudicina et al., 2014). In terms of rotation design, there is also variation between species in the factors determining the impact on soil carbon, for example, vining pea residues had a significantly higher C:N ratio (28) than forage pea (20) or faba bean (17) (Lupwayi and Soon, 2016). The possibilities for improving soil carbon offered by intercrops with grain legumes as opposed to sole crops are also worthy of consideration. The increase in root density (Li et al., 2006) and root biomass (Cong et al., 2015) in intercrops compared to sole crops can lead to increases in soil carbon (Cong et al., 2015).

The impact of grain legumes on soil structure is related not only to carbon inputs but also to the soil microbial community (See Biodiversity section) and the physical impact of grain legume roots and associated mycorrhizal hyphae. The root length of a grain legume plant may be only one tenth that of a cereal plant (Hamblin \& Tennant, 1987, Heeraman and Juma, 1993). Haynes and Beare (1997) suggested that since legume roots deposit material of higher $\mathrm{N}$ content, there is greater exploration of those aggregates by fungal hyphae, enhancing aggregate stability. Grain legume species differ in their ability to create and stabilize soil aggregates, with lupin shown to be more effective than pea in both these measures of soil structure (Chan and Heenan, 1996). This may relate to root length, architecture and/or exudation, but there is little comparative information available. Interaction with tillage is another important issue and under Mediterranean conditions, faba bean root systems have been found to respond positively to reduced tillage in terms of root length, diameter and biomass as a result of improved soil structure and increased water storage capacity (Muñoz-Romero et al., 2011).

Soil $\mathrm{pH}$ should be optimized for the crop along with an adequate supply of major and micronutrients for crop growth and function. One side-effect of the release of acids by legume roots is a gradual acidification of the soil, usually countered by periodic applications of lime, and partially countered by the alkalinity of the crop residues. Low soil pH can reduce the survival of rhizobium during phases of the rotations when no host plant is present (Carter et al., 1995).

\subsection{Reconnecting crop and livestock production}

Specialization in agriculture has been driven by a combination of policy and economics (Russelle et al., 2007; Hendrickson et al., 2008) facilitated by cheap energy. Spatial separation of livestock and feed production between continents and regions has resulted in widely acknowledged negative environmental consequences, for example, water pollution (Larsson and Granstedt, 2010) and loss of both crop diversity and biodiversity (De Fries et 
al. 2004). It has also resulted in arable farming systems becoming increasingly dependent on synthetic fertilizer for nutrients and in some arable areas, levels of top soil carbon are declining (Goidts and van Wesemael, 2007; Heikkinen et al., 2013). As a result, there is an increasing interest in Europe in reconnecting crop and livestock production not just at farm but at local and even continental levels (e.g. Moraine et al., 2014; Peyraud et al., 2014). On farms that are mixed, grain legumes can be used as home-produced high-protein feed without transport costs. Often, using home-produced grain legumes is economically viable as the value of the feed exceeds the market price (Preissel et al., 2017). Nevertheless, a mass return to mixed farming systems is unlikely for many reasons, including infrastructure costs associated with livestock housing, fences and watering points, and the knowledge needs of farmers. Pairing farms or developing groups of farms that trade different commodities in a structured way within a region is perhaps a more likely outcome as a means of overcoming both production constraints and local environmental issues (Asai and Langer, 2014; Moraine et al., 2016). Arable farms can then combine the nitrogen in manure with nitrogen from BNF to reduce reliance on synthetic fertilizer and build soil organic matter within the crop rotation. Franzluebbers et al. (2011) reported increases in crop yield at the farm level as a result of manure exchange between farms. This also has the potential to reduce leaching losses by reducing the amount of manure spread per unit land area within the region. Asai et al. (2014) found in 2009 that half of all Danish farms were involved in manure exchanges. Within the EU Regulation (834/2007) for organic farming, it is stipulated that livestock feed must be grown within the region, which provides an incentive for grain legume production close to farms producing organic chicken or pork without land to produce enough protein-rich feed.

\subsection{Designing grain legume production systems}

Growing more grain legumes in future requires changes to the cropping system, the sequence and the management of crops. To support this transition, the design of cropping systems can utilize several approaches, including field experiments to test cropping practices on-station, on-farm experiments where farmers test new practices on their farms, and cropping system planning tools. The latter are particularly relevant to assess environmental, economic and agronomic impacts of cropping system ex ante. Reckling et al. (2016a) found reduced trade-offs between economic and environmental impacts when legumes were introduced and showed that economic-environmental optimized cropping systems with legumes can be designed using a simple framework. Tools such as MASC (Sadok et al., 2009) and ROTOR (Bachinger and Zander, 2007) can also be used for a 
participatory process with farmers to design new systems. A combination of the different approaches to design cropping systems with legumes could promote implementation by farmers (Reckling et al., 2016c).

\section{Crop improvements necessary}

In order to make grain legumes into economically more attractive crops that farmers will grow, major advances in yield and yield stability need to be made and new markets need to be developed.

Pea is the most widely grown grain legume in Europe, but it suffers from poor standing ability, poor ground coverage and low competitive ability against weeds, along with relatively low protein (20-24\%) and, on many soils, low productivity. Faba bean is the second in area, the first in yield per hectare, and on account of its higher protein content (28-32\%), highest in protein yield, but is considered to be adapted to heavy or clay-rich soils and too sensitive to water deficit on sandy soils. For sandy, acid soils, the three agricultural lupins (white, yellow, and narrow-leafed) are well suited with deep rooting and good drought tolerance, but only white lupin achieves good ground coverage. The experience of the authors is that yellow lupin is the most drought-tolerant and suited to the sandiest soils, followed by narrow-leafed, and finally white. Both white and yellow lupin have higher protein contents (35-45\%) than the starchy pulses, while that of narrow-leafed lupin is close to that of faba bean. Lentil, chickpea and common bean all have protein contents in the same range as that of pea and have relatively low yields, but high values as they are primarily food rather than feed crops. Frost tolerance is limited in soybean and unknown in common bean. The diseases of the main grain legumes have been mentioned above, and all species could use better tolerance to the full suite of abiotic stresses. Thus, there is much to be done in breeding programmes, and each programme has its own set of priorities.

In terms of the remit of this paper, we will focus on factors affecting the cost of management and the value of the product. Weed control is a major problem when growing most grain legumes. Some species are less competitive than others, owing to very open canopies (semi-leafless pea and narrow-leafed lupin are two cases in point), and since their sowing densities are an order of magnitude less than those of cereals, ground coverage is later, regardless of the speed of germination and establishment. Because of their relatively low hectarages, the grain legumes have not attracted sufficient investment in development or licensing of herbicides. Induced mutagenesis has raised the level of Metribuzin tolerance to 
an acceptable value in Western Australian narrow-leafed lupin breeding (Si et al., 2009), and a similar strategy should work in other crops. Diversity of herbicides is as necessary to sustainability as biodiversity is, in order to prevent selection of herbicide-resistant weeds. The hypogeal germination habit of pea, lentil, chickpea and faba bean protects the cotyledonary buds from damage during weed-harrowing, but the corresponding growing points of the lupins, common bean and soybean are exposed to damage in this way.

Yield is the main breeding objective, and can be achieved through improved biomass production, better partitioning into seeds, and enhanced tolerance to biotic and abiotic stresses. Sources of resistance to many individual stresses have been found in germplasm of the various species and the search for other sources is continuous. Bringing those resistances into otherwise well adapted backgrounds requires investment and time, and technologies such as genome-wide association and genomic selection are in development in order to be able to identify first the gene regions conferring the enhanced traits, and then offspring carrying the desired combinations, rapidly and efficiently.

\section{Forward look:}

Europe's remarkable agricultural productivity can be partly attributed to specialization in high-yielding cereals and oilseeds grown using synthetic nitrogen fertilizer, well-developed supporting technology such as pesticides, and large imports of soy from North and South America for livestock feeding. However this productivity comes at a cost for the environment linked to imbalances in European cropping systems. Developing more sustainable systems is not about promoting legumes. It is about the effective rebalancing of farming and food in Europe using legumes. It is also about global change. In South America, cropping systems with more than $50 \%$ soy are common, so their cropping sequences are too simple, dominated by legumes. At the same time, enabled by imports of soy, farmers in Europe have reduced legume production to the point that most European cropping systems do not use any legumes at all. But is change really needed?

Europe is more self-sufficient in plant protein than is commonly implied. While Europe imports about $70 \%$ of the protein-rich material used for feed supplementation, it is actually about $70 \%$ self-sufficient in tradable plant protein when all grain and arable forage protein sources are considered (Murphy-Bokern et al., 2017). European farmers are as good as or better than farmers in legume-exporting countries at growing legumes, but they are especially good at growing cereals. Many economists would argue that the current situation reflects rational economic decision-making by farmers and wider economic advantage that the use of comparative advantage brings. However, we can speculate on a number of 
fundamental changes that determine the likelihood of a rebalancing of agriculture supported by legumes grown in Europe. These are to do with:

1. better assessment of the economic performance of legumes;

2. yield and yield stability; the economic value of supporting services;

3. the value of the crop produce;

4. gaining a market advantage from environmental effects;

5. broad-based transition in value chains; and

6. public policy support.

Taking these in turn, we start with the understanding that the real (farm-level) economic performance of legumes is higher than conventional gross margin analysis indicates. This means realizing the full farm-level economic value is a way forward (Preissel et al., 2015; Zander et al., 2016). However, even where the economic performance of legume crops is underestimated, there is consensus that there is still a lack of compelling economic grounds for growing legumes for many farmers. This means that in most situations, the technical performance of legume crops also needs to improve compared with competing crops. There is some good evidence that this is possible. Cereal crop yields are stagnating even though breeding continues to increase yield potential (Brisson et al., 2010). If the performance of cereals stagnates or even declines, and performance of legumes continues to increase, we will over time see the attractiveness of legumes for farmers increase. This scenario is supported by investment in plant breeding and improving cropping systems in particular.

The cost of crop inputs, especially nitrogen fertilizer, will also impact on prospects. The economic value of the biologically fixed nitrogen depends ultimately on the price of synthetic nitrogen fertilizer. Similarly, the value of other aspects of the break crop effect depends on the availability and cost of pesticide-based control of weed and other problems. In an excellent example of combining biological and economic research, Humphreys et al. (2012) identified a tipping point in the ratio of fertilizer nitrogen price and the farm-gate price of milk in Ireland. The scope for this effect in arable systems is somewhat lower although clearly the attractiveness of more diverse cropping sequences increases as the cost of maintaining intensive cereal production using synthetic fertilizer nitrogen and plant protection products increases.

The relationship between the price of grain legumes and the price of the most commonly grown or competing crop product will influence cropping decisions. In Bavaria, soybean production is competitive with wheat production when the price of soy exceeds twice that of 
the cereal (Schätzl and Halama, 2013). If the price of soy relative to wheat continues its rise then growing soya and other legumes will become competitive for more farmers in relevant regions. This increase in price reflects rapidly growing demand for soy from China. Using analysis of scenarios, Pilorge and Muel (2016) indicated that the current high prices for plant protein are here to stay. It is reasonable to conclude that protein will remain valuable compared with carbohydrate and oil increasing the potential for legumes in Europe with protein yield per hectare being a key determinant of success.

There is also definitely growing interest in higher process quality in the agri-food sector, particularly reduced negative environmental impacts (Murphy-Bokern and Kleeman, 2015). However, to gain from such market premiums gained through for example produce certification, it must be clear that legume crops support improved environmental performance that consumers recognize and reward. As is evident from this review, diversifying our cropping systems using legumes will bring environmental benefits, but these benefits are modest and probably not sufficient to drive large premiums.

In addition to changes in the individual fundamental factors outlined above, there is also the possibility of combinations of small changes leading to breakthroughs at the system level. Voisin et al. (2014) argued that legume production has been hindered by lock-in within incumbent structures and processes. For example, past trade agreements supported specialization in cereal production and stimulated infrastructure investment in processing large amounts of imported soybean meal. The resulting lock-in or dominance of the incumbent system is manifest for example in the market under-valuation of pea and faba bean in relation to their nutritional contribution in compound feeds. Voisin et al. (2014) argued that starting with combining niche high-value chains that give priority to a secure and high quality supply within regionalized systems, new broader structures and processes can be established. The theory of transition (Geels, 2011) indicates that such new systems can emerge when the effects of several niche innovators coincide. Eventually, new value chains, such as those exploiting food uses, may synergize with each other and with the dominant system.

Developments reviewed here have provided a rich resource of practical knowhow embedded in farming and food businesses which can now be used to improve systems. Such an open 'multi-actor' approach complements the research we have had to date, largely about components of systems. Overall, a four-fold increase in grain legume production from the 2014 level to about 6.5 million ha ( $6 \%$ of the arable area) would be beneficial from a farming 
systems perspective. Given the huge market for plant protein now met by imports, there is no fundamental internal market constraint on this high level of growth. If we assume that the output of non-legume crops remains stable (due to rotation benefits and the general technical progress in eastern Europe), the aforementioned four-fold increase would result in an increase in the supply of protein from EU-grown grain legumes from 1.37 million tonnes of plant protein to 5.48 million tonnes. This compares with a total demand for 54 million tonnes of 'tradable' arable plant protein including a net import of 15 million tonnes of soy protein. This would reduce the deficit in high protein commodities from about $70 \%$ to about $50 \%$. This might be regarded as a small effect, but we can conclude here that it comes with broad complementary agronomic, economic, environmental, and social impacts. Unless this change causes a reduction in cereal exports, we can expect improvement in Europe's balance of trade. Given that the proportion of grain legume crops in European organic systems is $12 \%$ on average, and frequently as high as $20 \%$, further expansion in conventional cropping to $10 \%$ of the arable area to approach the levels sustained in Canada and Australia is a reasonable target. This would radically reduce reliance on imported soy. The challenge for the future is the optimal expansion of production of legume crops to while maximizing complementary impacts so that change can be economically, socially and politically sustained. For this, European legumes must be competitive for land at produce prices that are competitive with imports.

\section{Acknowledgements}

This study was supported by the EU FP7 project Legume-supported cropping systems for Europe (245216 CP-FP, http://www.legumefutures.de), the FACCE - ERA-Net+ project Climate CAFE (Climate Change Adaptability of cropping and Farming systems for Europe), and the Scottish Government Strategic Research Programme. Parts of this review are based on a study carried out by some of the authors, "The environmental role of protein crops in the new common agricultural policy" (Bues et al., 2013) commissioned by the European Parliament, available on line at http://www.europarl.europa.eu/studies. We thank Charles Cernay from INRA, UMR 211 Agronomie, in France for re-calculating yield stability data used in Table 3.

\section{References}

Abeliotis, K., Detsis, V., Pappia, C., 2013. Life cycle assessment of bean production in the Prespa National Park, Greece. J. Clean. Prod. 41, 89-96. 
Adesogan, A.T., Salawu, M.B., Williams, S.P., Fisher, W.J., Dewhurst, R.J., 2004. Reducing concentrate supplementation in dairy cow diets while maintaining milk production with pea-wheat intercrops. J. Dairy Sci. 87, 3398-3406.

Agreste, 2013. Des rendements proches d'une année moyenne pour les céréales à paille, mais inférieurs pour les cultures de printemps. In: Agreste conjoncure - Infos rapides. Mountreuil sous Bois: pp: $5 . \quad$ URL http://agreste.agriculture.gouv.fr/conjoncture/grandes-cultures-etfourrages/article/infos-rapides-grandes-cultures-des-9408 [29.10.2016].

Albrecht R., Guddat C., 2004. Welchen Wert haben Körnerleguminosen in der Fruchtfolge. Thüringer Landesanstalt für Landwirtschaft. URL: www.tll.de/ainfo/pdf/kleg0104.pdf [29.10.2016].

Andersen, M., Hauggaard-Nielsen, H., Ambus, P., Jensen, E.S., 2004. Biomass production, symbiotic nitrogen fixation and inorganic $\mathrm{N}$ use in dual and tri-component annual intercrops. Plant Soil 266, 273-287.

Angus, J.F., Kirkegaard, J.A., Hunt, J.R., Ryan, M.H., Ohlander, L., Peoples, M.B., 2015. Break crops and rotations for wheat. Crop and Pasture Science, 66, 523-552.

Annicchiarico, P., lannucci, A., 2008. Adaptation strategy, germplasm type and adaptive traits for field pea improvement in Italy based on variety responses across climatically contrasting environments. Field Crop Res. 108, 133-142.

Anil, L., Park, J., Phipps, R.H., Miller, F.A., 1998. Temperate intercropping of cereals for forage: a review of the potential for growth and utilization with particular reference to the UK. Grass Forage Sci. 53, 301-307.

Arnoldi, A., Zanoni,C., Lammi, C., Boschin, G. 2015. The role of grain legumes in the prevention of hypercholesterolemia and hypertension. Crit. Rev. Plant Sci. 34 , 144168.

Arvidsson, J., Håkansson, I., 2014. Response of different crops to soil compaction - Shortterm effects in Swedish field experiments. Soil Till. Res. 138, 56-63.

Asai, M., Langer, V., 2014. Collaborative partnerships between organic farmers in livestockintensive areas of Denmark. Org. Agric. 4, 63-77.

Asai, M., Langer, V., Frederiksen, P., Jacobsen, B.H. 2014. Livestock farmer perceptions of successful collaborative arrangements for manure exchange: a study in Denmark. Agric. Syst. 128, 55-65.

Aslaksen, M.A., Kraugerud, O.F., Penn, M., Svihus, B., Denstadli, V., Jorgensen, H.Y.,Hillestad, M., Krogdahl, A., Storebakken, T., 2007. Screening of nutrient digestibilities and intestinal pathologies in Atlantic salmon, Salmo salar, fed diets with legumes,oilseeds, or cereals. Aquaculture 272, 541-555.

Avola, G., Tuttobene, R., Gresta, F., Abbate, V., 2008. Weed control strategies for grain legumes. Agron. Sust. Dev. 28, 389-395.

Ayadi, F.Y., Rosentrater, K.A., Muthukumarappan, K., 2012. Alternative protein sources for aquaculture feeds. J Aquacult. Feed Sci. Nutr. 4,1-26.

Baddeley, J.A., Jones, S., Topp, C.F.E., Watson, C.A., Helming, J.,Stoddard, F.L. 2013. Biological nitrogen fixation (BNF) by legume crops in Europe. Legume Futures Report 1.5. www.legumefutures.de [29.10.2016].

Bachinger, J., Zander, P. 2007. ROTOR, a tool for generating and evaluating crop rotations for organic farming systems. Eur. J. Agron. 26, 130-143.

Barton L., Thamo T., Engelbrecht D., Biswas W.K., 2014. Does growing grain legumes or applying lime cost effectively lower greenhouse gas emissions from wheat production in a semi-arid climate? J. Clean. Prod. 83, 194-203.

Bassett, C., Boye, J., Tyler, R., Oomah, B. D. 2010. Molecular, functional and processing characteristics of whole pulses and pulse fractions and their emerging food and nutraceutical applications. Food Res. Int. 43, 397-659.

Baumgartner, D.U., de Baan, L., Nemecek,T., 2008. European grain legumes - environmentfriendly animal feed? Life cylce assessment of pork, chicken meat, egg, and milk production. In: Final Report WP2.2, Environmental Analysis of the Feed Chain, Grain 
Legumes Integrated Project. Agroscope Reckenholz-Tänikon Research Station (ART), Zürich: pp: 112.

Beaudoin, N., Saad, J.K., Van Laethem, C., Machet, J.M., Maucorps, J., Mary, B., 2005. Nitrate leaching in intensive agriculture in Northern France: effect of farming practices, soils and crop rotations. Agric. Ecosys. Environ. 111, 292-310.

Bedoussac, L., Journet, E-P., Hauggaard-Nielsen, H., Naudin, C., Corre-Hellou, G., Jensen, E.S., Prieur, L., Justes, E., 2015. Ecological principles underlying the increase of productivity achieved by cereal-grain legume intercrops in organic farming. A review. Agron. Sust. Dev. 35, 911-935.

Begum, N., Guppy, C., Herridge, D., Schwenke, G., 2014. Influence of source and quality of plant residues on emissions of $\mathrm{N}_{2} \mathrm{O}$ and $\mathrm{CO}_{2}$ from a fertile, acidic Black Vertisol. Biol. Fertil. Soils 50, 499-506.

Bengough, A.G., Young, I.M., 1993. Root elongation of seedling peas through layered soil of different penetration resistances. Plant Soil 149, 129-139.

Benton, T.G., Vickery, J.A., Wilson, J.D., 2003. Farmland biodiversity: is habitat heterogeneity the key? Trends Ecol. Evol., 18, 182-188.

Berg, Å., Jonsson, M., Lindberg, T., Källebrink, K.-G., 2002. Population dynamics and reproduction of northern lapwings vanellus vanellus in a meadow restoration area in central Sweden. Ibis 144, E131-E140.

Bertoglio, J.C., Calvo, M.A. , Hancke, J.L. , Burgos, R.A., Riva, A. , Morazzoni, P., Ponzone, C., Magni, C., Duranti, M., 2011. Hypoglycemic effect of lupin seed $\gamma$-conglutin in experimental animals and healthy human subjects. Fitoterapia, 82, 933-938.

Bilalis, D., Papastylianou, P., Konstantas, A., Patsiali, S., Karkanis, A., 2010. Weedsuppressive effects of maize-legume intercropping in organic farming. Int. J. Pest Manage. 56,173-181

Billen, G., Beusen, A., Bouwman, L., Garnier, J., 2010. Anthropogenic nitrogen autotrophy and heterotrophy of the world's watersheds: past, present, and future trends. Global Biogeochem. Cyc. 24, GBOA11.

Billen, G., Garnier, J., Thieu, V., Silvestre, M., Barles, S., Chatzimpiros, P., 2012. Localising the nitrogen imprint of the Paris food supply: the potential of organic farming and changes in human diet. Biogeosciences 9, 607-616.

Bouxin, A. 2014. Food and feed statistical yearbook 2013. Brussels, Belgium: FEFAC, European Feed Manufacturers' Association.

Bowerman, P., Clare, R.W., 1976. Comparison of nitrogen rates and time of application for continouous winter wheat and wheat after beans. Exp. Husbandry, 42-54.

Brisson, N., Gate, P., Gouache, D., Charmet, G., Oury, F-X., Huard, F., 2010. Why are wheat yields stagnating in Europe? A comprehensive data analysis for France. Field Crop Res. 119, 201-212.

Brock P.M., Muir S., Herridge D.F. \& Simmons A., 2016. Cradle-to-farmgate greenhouse gas emissions for 2-year wheat monoculture and break crop-wheat sequences in southeastern Australia. Crop Pasture Sci. 67, 812-822.

Brodrick, S.J., Sakala, M.K., Giller, K.E., 1992. Molybdenum reserves of seed, and growth and $\mathrm{N}_{2}$ fixation by Phaseolus vulgaris L. Biol. Fertil. Soils 13, 39-44.

Brooker, R.W., Bennett, A.E., Cong-W-F, Daniell, T.J., George, T.S., Hallett, P.D., Hawes, C., lannetta, P.P.M., Jones, H.G., Karley, A.J., Li, L., McKenzie, B.M., Pakeman, R.J., Paterson, E., Schöb, C., Shen, J,, Squire, G., Watson, C.A., Zhang, C., Zhang, F., Zhang, J., White, P.J., 2014. Improving intercropping: A synthesis of research in agronomy, plant physiology and ecology. New Phytol. 206, 107-117.

Brouwer, F., 2006. Main trends in agriculture. In: Agriculture for sustainable development: A dialogue on societal demand, pressures and options for policy. SASSPO-SSP4022698. Background Note 1. www.mtt.fi/sasspo/SASSPO HKI BN1-1.pdf [29.10.2016].

Bues, A., Preißel, S., Reckling, M., Zander, P., Kuhlmann, T., Topp, K., Watson,C., Lindström, K., Stoddard, F.L., Murphy-Bokern, D., 2013. The environmental role of 
protein crops in the new Common Agricultural Policy. In: Directorate General for Internal Policies, Agriculture and Rural Development, European Union, Brussels, pp: 113, $\quad$ www.europarl.europa.eu/RegData/etudes/.../IPOLAGRI ET(2013)495856 EN.pdf [29.10.2016].

Bulson, H.A.J., Snaydon, R.W., Stopes, C.E., 1990. Intercropping autumn-sown beans and wheat: effects on weeds under organic farming conditions. In: Unwin, R. (Ed) Crop Protection in Organic and Low Input Agriculture. British Crop Protection Council, Bracknell, UK, pp. 55-62.

Bulson, H.A.J., Snaydon, R.W., Stopes, C.E., 1997. Effects of plant density on intercroppedwheat and field beans in an organic farming system. J. Agric. Sci. (Cambr.) 128, 59-71.

Bundesministerium für Ernährung und Landwirtschaft, 2013. Mbt-0104160-0000 vorläufige herbstaussaatfläche für die ernte. http://www.bmel.de/EN [29.10.2016].

Canfield, D.E., Glazer, A.N., Falkowski, P.G. 2010. The evolution and future of earth's nitrogen cycle. Science 330, 192-196

Cardador, L., De Cáceres, M., Giralt, D., Bota, G., Aquilué, N., Arroyo, B., Mougeot, F., Cantero-Martínez, C., Viladomiu, L., Rosell, J., Casas, F., Estrada, A., ÁlvaroFuentes, J., Brotons, L. 2015. Tools for exploring habitat suitability for steppe birds under land use change scenarios. Agric. Ecosyst. Environ. 200, 119-125.

Carpena, R., Esteban, E., Sarro, M., Peñaloza, J., Garate, A., Lucena, J.,Zornoza, P., 2000. Boron and calcium distribution in nitrogen fixing pea plants. Plant Sci. 151,163-170.

Carranca, C., Varennes, A.D., Rolston, D., 1999. Biological nitrogen fixation by fababean, pea and chickpea, under field conditions, estimated by the ${ }^{15} \mathrm{~N}$ isotope dilution technique. Eur. J. Agron 10, 49-56.

Carranca, C., Oliveira, A., Pampulha, M.E., Torres, M.O., 2009. Temporal dynamics of soil nitrogen, carbon and microbial activity in conservative and disturbed fields amended with mature white lupine and oat residues. Geoderma 151, 50-59.

Carter, J.M., Tieman, J.S., Gibson, A.H., 1995. Competitiveness and persistence of strains of rhizobia for faba bean in acid and alkaline soils. Soil Biol. Biochem. 27, 617-623.

Cederberg, C., Flysiö, A. 2004. Environmental assessment of future pig farming systems. Quantifications of three scenarios from the food 21 synthesis work. In: SIK-rapport. The Swedish Institute for Food and Biotechnology (SIK), Göteborg, pp. 54.

Cernay, C., Ben-Ari, T., Pelzer, E., Meynard, J.-M., Makowski, D., 2015. Estimating variability in grain legume yields across Europe and the Americas. Sci. Rep. 5.

Chalk, P.M., 1998. Dynamics of biologically fixed $N$ in legume-cereal rotations: A review. Aust. J. Ag. Res. 49, 303-316.

Chalk, P.M., Souza, R.F., Urquiaga,S., Alves, B.J.R.,Boddey, R.M. 2006. The role of arbuscular mycorrhiza in legume symbiotic performance. Soil Biol.Biochem. 38, 2944 $-2951$.

Chan, K.Y., Heenan, D.P., 1996. The influence of crop rotation on soil structure and soil physical properties under conventional tillage. Soil Till. Res. 37, 113-125.

Charles, R., Vuilloud, P., 2001. Pois protéagineux et azote dans la rotation. Revue Suisse Agric. 33,365-370.

Collette, L. Hodgkin, T., Kassam, A., Kenmore, P., Lipper, L., Nolte, C., Stamoulis, K., Steduto, P., 2011. Save and Grow. Rome, Italy: Food and Agriculture Organization of the United Nations. www.fao.org/docrep/014/i2215e/i2215e.pdf [29.10.2016].

Cong, W-F., Hoffland, E., Long, L., Six, J., Sun, J.H., Bao, X.G., Zhang, F.S., Van der Werf. W., 2015. Intercropping enhances soil carbon and nitrogen. Global Change Biol. 21, $1715-1726$.

Connor, D.J., 2004. Designing cropping systems for efficient use of limited water in southern Australia. Eur. J. Agron. 21, 419-431.

Cook, R.J., 2003. Take-all of wheat. Physiol. Mol. Plant Pathol. 62, 73-86. 
Corre-Hellou, G., Crozat, Y., 2005. $\mathrm{N}_{2}$ fixation and $\mathrm{N}$ supply in organic pea (Pisum sativum L.) cropping systems as affected by weeds and pea weevil (Sitona lineatus L.). Eur. J. Agron. 22, 449-458.

Corre-Hellou, G., Dibet, H., Hauggaard-Nielsen, A, Crozat, Y., Gooding, M., Ambus, P., Dahlmann, C., von Fragstein, P., Pristeri, A., Monti, M., Jensen, E.S., 2011. Competitive ability of pea-barley intercrops against weeds and interactions with crop productivity and soil N availability. Field Crop Res. 122, 264-272.

Corre-Hellou, G., Fustec, J., Crozat, Y., 2006. Interspecific competition for soil $\mathrm{N}$ and its interaction with $\mathrm{N}_{2}$ fixation, leaf expansion and crop growth in pea-barley intercrops. Plant Soil 282,195-208.

Crépon, K., 2006. Nutritional value of legumes (pea and faba bean) and economics of their use. In: Garnsworthy, P.C., Wiseman, J. (Eds.) Recent Advances in Animal Nutrition. Nottingham Univ. Press, Nottingham, UK, pp. 331-366.

Crépon, K., Marget, P., Peyronnet, C., Carrouée, B., Arese, P., Duc, G., 2010. Nutritional value of faba bean (Vicia faba L.) seeds for feed and food. Field Crop Res. 115, 329339.

Crews, T.E., Peoples, M.B., 2004. Legume versus fertilizer sources of nitrogen: ecological tradeoffs and human needs. Agr. Ecosyst. Environ. 102, 279-297.

Dachler, M., Köchl, A. 2003. Der einfluss von fruchtfolge, vorfrucht, stickstoffdüngung und einarbeitung der ernterückstände auf ertrag und rohproteingehalt von winterweizen und nachfolgender sommergerste. Die Bodenkultur 54, 23-34.

Davis J., Sonesson U., Baumgartner D.U., Nemecek T., 2010. Environmental impact of four meals with different protein sources: Case studies in Spain and Sweden. Food Res. Int. 43, 1874-1884.

Day, L., 2013. Proteins from land plants - potential resources for human nutrition and food security. Trends Food Sci. Tech. 32, 25-42.

Decourtye, A., Mader, E., Desneux, N., 2010. Landscape enhancement of floral resources for honey bees in agro-ecosystems. Apidologie 41, 264-277.

Defra and AHDB, 2012. Defra and AHDB, 2012. HGCA/AHDB Winter Planting Survey 2012. A.M. Intelligence (Ed.). https://cereals.ahdb.org.uk/media/5316/winter planting survey 2012.pdf [29.10.2016].

DeFries, R.S., Foley, J.A., Asner, G.P., 2004. Land-use choices: balancing human needs and ecosystem function. Front. Ecol. Environ. 2, 249-257.

Denton, M. D., Pearce, D.J., Peoples, M.B., 2013. Nitrogen contributions from faba bean (Vicia faba L.) reliant on soil rhizobia or inoculation. Plant Soil 365, 363-374.

DESTATIS, https://www.destatis.de/EN/FactsFigures/EconomicSectors/AgricultureForestryFisher ies/FieldCropsGrassland/FieldCropsGrassland.html [30/10/2016]

DG Agri, 2009. Agriculture in the European Union - Statistical and economic information 2008. http://ec.europa.eu/agriculture/agrista/2008/table en/index.htm. [29.10.2016]

Diaz, D., Morlacchini, M., Masoero, F., Moschini, M., Fusconi, G., Piva, G., 2006. Pea seeds (Pisum sativum), faba beans (Vicia faba var. minor) and lupin seeds (Lupinus albus var. multitalia) as protein sources in broiler diets: effect of extrusion on growth performance. Ital. J. Anim.Sci. 5, 43-53.

Dicks, L.V., Ashpole, J.E. , Dänhardt, J., James, K., Jönsson, A., Randall, N., Showler, D.A., Smith, R.K. , Turpie, S., Williams, D., Sutherland, W.J., 2013. Farmland conservation: Evidence for the effects of interventions in northern and western europe. Pelagic Publishing, Exeter. pp: 504..

Divito, G.A., Sadras. V.O., 2014. How do phosphorus, potassium and sulphur affect plant growth and biological nitrogen fixation in crop and pasture legumes? A metaanalysis. Field Crop. Res. 156, 161-171.

Dixon, R. M., Hosking, B.J.. 1992. Nutritional value of grain legumes for ruminants. Nutr. Res. Rev. 5, 19-43. 
Donald, R.F., Green, R.E., Heath, M.F., 2001. Agricultural intensification and the collapse of Europe's farmland bird populations. Proc. R. Soc. Lond. B, 268, 25-29.

Dong, Z., Wu, L., Kettlewell, B., Caldwell, C.D., Layzell, D.B., 2003. Hydrogen fertilization of soils - is this a benefit of legumes in rotation? Plant, Cell Environ. 26, 1875-1879.

Dordas, C.A., Lithourgidis, A.S., 2011. Growth, yield and nitrogen performance of faba bean intercrops with oat and triticale at varying seeding ratios. Grass Forage Sci. 66, 569577.

Döring, T.F., Knapp, S., and Cohen, J.E., 2015. Taylor's power law and the stability of crop yields. Field Crops Research 183, 294-302.

Dourmad, J., Ryschawy, J., Trousson, T., Bonneau, M., Gonzàlez, J., Houwers, H.W.J., Hviid, M., Zimmer, C., Nguyen, T.L.T, Morgensen, L., 2014. Evaluating environmental impacts of contrasting pig farming systems with life cycle assessment. Animal 8, 2027-2037.

Duc G., Mariotti A., Amarger N., 1988. Measurements of genetic variability for symbiotic dinitrogen fixation in fieldgrown faba bean (Vicia faba L.) using a low level ${ }^{15} \mathrm{~N}$-tracer technique. Plant Soil 106, 269-276.

Dunbabin, V., Diggle, A., Rengel, Z., 2003. Is there an optimal root architecture for nitrate capture in leaching environments? Plant, Cell Environ. 26, 836 -844.

Dusenbury, M.P., Engle, R.E., Miller, R.P., Lemke, R.L., Wallander, R., 2008. Nitrous oxide emissions from a northern Great Plains soil as influenced by nitrogen management and cropping systems. J. Environ. Qual. 37, 542-550.

Drury, C. F. and Tan, C. S., 1995. Long-term (35 years) effects of fertilization, rotation and weather on corn yields. Can. J. Plant Sci. 75, 355-362.

Dyke, G.V., Slope, D.B., 1978. Effects of previous legume and oat crops on grain-yield and take-all in spring barley. J Agr. Sci. 91, 443-451.

Egle, K., Romer, W., Keller, H., 2003. Exudation of low molecular weight organic acids by Lupinus albus L., Lupinus angustifolius L. and Lupinus luteus L. as affected by phosphorus supply. Agronomie 23, 511-518.

Eisenhauer, N., Milcu, A., Sabais, A.C.W., Bessler, H., Weigelt, A., Engels, C., Scheu, S., 2009. Plant community impacts on the structure of earthworm communities depend on season and change with time. Soil Biol. Biochem. 41, 2430-2443.

Engström L., Lindén B., 2009. Importance of soil mineral $\mathrm{N}$ in early spring and subsequent net $\mathrm{N}$ mineralisation for winter wheat following winter oilseed rape and peas in a milder climate, Acta Agr. Scand. 59, 402-413.

European Commission, 2016. Commission Staff Working Document. Review of greening after one year. SWD 218. http://ec.europa.eu/agriculture/direct-support/pdf/2016staff-working-document-greening en.pdf [30/10/2016]

European Commission, 2013. Facts and figures on organic agriculture in the European Union. http://ec.europa.eu/agriculture/markets-and-prices/more-reports/pdf/organic2013_en.pdf [30/10/2016]

Eurostat, 2016. European Commission, Brussels, Belgium. http://ec.europa.eu/eurostat [29.10.2016].

Evans, A., Vickery, J., Shrubb, M., 2004. Importance of overwintered stubble for farmland bird recovery: a reply to Potts. Bird Study 51, 94-96.

FAO, 2004. Protein sources for the animal feed industry. In: Proceedings of an expert consultation and workshop, Bangkok, 29 April - 3 May 2002. Rome, Italy: Food and Agriculture Organisation. www.fao.org/3/a-y5019e.pdf [29.10.2016].

FAOstat, 2016. Statistics database of the Food and Agriculture Organization of the United Nations. http://www.fao.org/statistics/databases/en/ [30/10/2016].

FEFAC, 2014. The compound feed industry in the EU livestock economy. http://www.fefac.eu/ [29/10/2016].

Fenwick, D.E., Oakenfull, D., 1983. Saponin content of food plants and some prepared foods. J. Sci. Food Agric. 34, 186-191. 
Fernandez-Aparicio, M., Sillero, J.C., Rubiales, D., 2007. Intercropping with cereals reduces infection by Orobanche crenata in legumes. Crop Protect. 26, 1166-1172.

Fox, J.E., Gulledge, J., Engelhaupt, E., Burow, M.E., McLachlan, J.A., 2007. Pesticides reduce symbiotic efficiency of nitrogen-fixing rhizobia and host plants. Proc. Natl. Acad. Sci. U.S.A, 104, 10282-10287.

Franche, C., Lindström, K., Elmerich, C., 2009. Nitrogen-fixing bacteria associated with leguminous and non-leguminous plants. Plant Soil 321, 35-59.

Franzluebbers, A.J., Sulc, R.M., Russelle, M.P., 2011. Opportunities and challenges for integrating North-American crop and livestock systems. In: Lemaire, G., Hodgson, H., Chabbi, A. (Eds.), Grassland Productivity and Ecosystems Services, CABInternational, London, pp. 208-217.

Frimpong, K., Yawson, D., Baggs, E., Agyarko, K., 2011. Does incorporation of cowpeamaize residue mixes influence nitrous oxide emission and mineral nitrogen release in a tropical luvisol? Nutr. Cycl. Agroecosys. 91, 281-292.

Froidmont, E., Bartiaux-Thill, N., 2004. Suitability of lupin and pea seeds as a substitute for soybean meal in high-producing cow feed. Anim. Res. 53, 475-487.

Fustec, J., Lesuffleur, F., Mahieu, S., Cliquet, J.B., 2010. Nitrogen rhizodeposition of legumes. A review. Agron. Sustain. Dev. 30, 57-66.

Garcia-Launay, F., Werf, H., Nguyen, T., Tutour, L., Dourmad, J., 2014. Evaluation of the environmental implications of the incorporation of feed-use amino acids in pig production using Life Cycle Assessment. Livest. Sci. 161, 158-175.

Garrison, A.J., Miller, A.D., Ryan, M.R., Roxburgh, S.H., Shea, K., 2014. Stacked Crop Rotations Exploit Weed-Weed Competition for Sustainable Weed Management. Weed Sci. 62, 166-176.

Gatel, F., 1994. Protein quality of legume seeds for non-ruminant animals: A literature review. Anim. Feed Sci. Technol. 45, 317-348.

Gaulin, E., Jacquet, C., Bottin, A., Dumas, B., 2007. Root rot disease of legumes caused by Aphanomyces euteiches. Mol. Plant. Pathol. 8, 539-548.

Geels, F.W. 2011. The multi-level perspective on sustainability transitions: response to seven criticisms. Environ. Innov. Soc. Transit. 1, 24-40.

Gelder, J.W. van, Kammeraat, K., Kroes, H. 2008. Soy consumption for feed and fuel in the European Union. Profundo Economic Research. https://milieudefensie.nl/publicaties/rapporten/soy-consumption-for-feed-and-fuel-inthe-european-union [30/10/2016]

Gervois, S., Ciais, P., de Noblet-Ducoudré, N., Brisson, N., Vuichard, N., Viovy, N., 2008. Carbon and water balance of European croplands throughout the 20th century. Global Biogeochem. Cy. 22, 13-19.

Ghaley, B.B., Hauggaard-Nielsen, H., Høgh-Jensen, H., Jensen, E.S., 2005. Intercropping of wheat and pea as influenced by nitrogen fertilization. Nutr. Cycl. Agroecosys. 73, 201-212

Giambalvo, D., Stringi, L., Durante, G., Amato, G., Frenda, A.S., 2004. Nitrogen efficiency component analysis in wheat under rainfed mediterranean conditions: Effects of crop rotation and nitrogen fertilization. In: Cantero-Martínez, C, Gabiña, D. (Eds.) Mediterranean rainfed agriculture: Strategies for sustainability. Mediterranean Agronomic Institute of Zaragoza, Zaragoza, pp. 169-173.

Gillings, S., Newson, S.E., Noble, D.G., Vickery, J.A., 2005. Winter availability of cereal stubbles attracts declining farmland birds and positively influences breeding population trends. Proc. R. Soc. B 272, 733-739.

Glencross, B., Hawkins, W., Evans, D., Rutherford, N., Dods, K., McCafferty, P., Sipsas, S., 2008. Evaluation of the influence of Lupinus angustifolius kernel meal on dietary nutrient and energy utilization efficiency by rainbow trout (Oncorhynchus mykiss). Aquacult. Nutr. 14, 129-138.

Goidts, E., van Wesemael, B., 2007. Regional assessment of soil organic carbon changes under agriculture in Southern Belgium (1955-2005). Geoderma 141, 341-354. 
Golding A.-L., Dong Z., 2010. Hydrogen production by nitrogenase as a potential crop rotation benefit. Environ. Chem. Lett. 8, 101-121.

Gooding, M.J., Kasynova, E., Ruske, R., Hauggaard-Nielsen, H., Jensen, E.S., Dahlmann, C., Fragstein, P. von, Dibet, A., Corre Hellou, G., Crozat, Y., Pristeri, A., Romeo, M., Monti, M., Launay, M., 2007. Intercropping with pulses to concentrate nitrogen and sulphur in wheat. J. Agric. Sci. 145, 469-479.

Graf, D.R.H., Zhao, M., Jones, C.M., Hallin, S., 2016. Soil type overrides plant effect on genetic and enzymatic $\mathrm{N}_{2} \mathrm{O}$ production potential in arable soils. Soil Biol. Biochem. $100,125-128$.

Green, A.G., Brown, A.H.D., Oram, R.N., 1980. Determination of outcrossing rate in a breeding population of Lupinus albus L. (white lupin). Z. Pflanzenzüchtung 84, 181191.

Gronle, A., Hess, J., Böhm, H., 2015. Weed suppressive ability in sole and intercrops of pea and oat and its interaction with ploughing depth and crop interference in organic farming. Org. Agric. 5, 39-51.

Gruber, S., Wahl, E., Zikeli, S., Claupein, W., 2012. Perspektiven und Grenzen der Unkrautregulierung bei Linsen (Lens culinaris) im ökologischen Landbau. J. Kulturpfl. 64, 365-377.

Hamblin, A., Tennant, D., 1987. Root Length Density and Water Uptake in Cereals and Grain Legumes: How well are they Correlated? Aust. J. Agric. Res. 38, 513-27.

Harland, J.I., Haffner, T.A., 2008. Systematic review, meta-analysis and regression of randomised controlled trials reporting an association between an intake of circa $25 \mathrm{~g}$ soya protein per day and blood cholesterol. Atherosclerosis, 200, 13-27.

Hauggaard-Nielsen, H., Ambus, P., Jensen, E.S., 2001. Temporal and spatial distribution of roots and competition for nitrogen in pea-barley intercrops - a field study employing 32P technique. Plant Soil 236, 63-74.

Hauggaard-Nielsen, H., Ambus, P., Jensen, E.S., 2003. The comparison of nitrogen use and leaching in sole cropped versus intercropped pea and barley. Nutr. Cycl. Agroecosyst. 65, 289-300.

Hauggaard-Nielsen, H., Andersen, M.K., Jørnsgaard, B., Jensen, E.S., 2006. Density and relative frequency effects on competitive interactions and resource use in pea-barley intercrops. Field Crop Res. 95, 256-267.

Hauggaard-Nielsen, H., Jørnsgaard, B., Kinane, J., Jensen, E.S., 2008. Grain legumecereal intercropping: the practical application of diversity, competition and facilitation in arable and organic cropping systems. Renew. Agric. Food Sys. 23, 3-12.

Hauggaard-Nielsen, H., Gooding, M., Ambus, P., Corre-Hellou, G., Crozat, Y., Dahlmann, C., Dibet, A., v. Fragstein, P., Pristeri, A., Monti, M., Jensen, E.S. 2009. Pea-barley intercropping for efficient symbiotic $\mathrm{N}_{2}$-fixation, soil $\mathrm{N}$ acquisition and use of other nutrients in European organic cropping systems. Field Crop Res. 113, 64-71.

Haymes, R., Lee, H.C., 1999. Competition between autumn and spring planted grain intercrops of wheat (Triticum aestivum) and field bean (Vicia faba). Field Crop Res. 62, 167-176.

Haynes, R.J.,Beare, M.H., 1997. Influence of six crop species on aggregate stability and some labile organic fractions. Soil Biol. Biochem. 29. 1647-1653

Heeraman, D.A., Juma, N.G., 1993. A comparison of minirhizotron, core and monolith methods for quantifying barley (Hordeum vulgare L.) and fababean (Vicia faba L.) root distribution. Plant Soil 148, 29-41.

Heikkinen, J., Ketoja, E., Nuutinen, V. \& Regina, K., 2013. Declining trend of carbon in Finnish cropland soils in 1974-2009. Global Change Biol. 19, 1456-1469.

Helming, J., Kuhlman, T., Linderhof, V., and Oudendag, D. 2014. Impacts of legume scenarios. Legume Futures Report 4.5. Available from www.legumefutures.de.

Hénault, C., Grossel, A., Mary, B., Roussel, M., Léonard, J., 2012. Nitrous Oxide Emission by Agricultural Soils: A Review of Spatial and Temporal Variability for Mitigation. Pedosphere, 22, 426-433. 
Hendrickson, J., Sassenrath, G.F., Archer, D., Hanson, J., Halloran, J., 2008. Interactions in integrated US agricultural systems: the past, present and future. Renew. Agric. Food Syst. 23, 314-324.

Herridge, D., Rose, I. 2000. Breeding for enhanced nitrogen fixation in crop legumes. Field Crop Res. 65, 229-248.

Hoste, R., Bolhuis, J., 2010. Soya consumption in the Netherlands. Rapport-LandbouwEconomisch Instituut, (2010-059).

Houdijk, J.G.M., Smith, L.A., Tarsitano, D., Tolkamp, B.J., Topp, C.E.F., Masey-O'Neill, H., White, G., Wiseman, J., Kightley, S., Kyriazakis, I. 2013. Peas and faba beans as home grown alternatives for soya bean meal in grower and finisher pig diets. Garnsworthy, P.C., Wiseman, J. (Eds.) Recent Advances in Animal Nutrition. Nottingham Univ. Press, Nottingham, UK, pp. 145-175.

Hubbard, V.C., Jordan, D., Stecker, J.A., 1999. Earthworm response to rotation and tillage in a Missouri claypan soil. Biol. Fert. Soils 29, 343-347.

Huhtanen, P., Hetta, M., Swensson, C., 2011. Evaluation of canola meal as a protein supplement for dairy cows: A review and a meta-analysis. Can. J. Anim. Sci. 91, 529543.

Huisman, J., Jansman, A.J.M., 1991. Dietary effect and some analytical aspects of antinutritional factors in peas (Pisum sativum), common beans (Phaseolus vulgaris) and soybeans (Glycine max L.) in monogastric farm animals: a literature review. Nutr. Abstr. Review (Ser. B) 60, 901-921.

Humphreys, J., Mihailescu E., Casey I.A., 2012. An economic comparison of systems of dairy production based on $\mathrm{N}$ fertilised grass and grass-white clover grassland in a moist maritime environment. Grass Forage Sci. 67, 519-525.

Ingalls, J.R., McKirdy, J.A. 1974. Faba bean as a substitute for soybean meal or rapeseed meal in rations for lactating cows. Can. J. Anim. Sci. 54, 87-89.

IPCC, 2006. IPCC Guidelines for National Greenhouse Gas Inventories, Prepared by the National Greenhouse Gas Inventories Programme, Inst. for Global Strategies (IGES), Hayama

Itakura, M., Uchida, Y., Akiyama, H., Hoshino-Takada, Y., Shimomura, Y., Morimoto, S., Tago, K., Wang, Y., Hayakawa, C., Uetake, Y., Sánchez, C., Eda, S., Hayatsu, M., Minamisawa, K., 2013. Mitigation of nitrous oxide emissions from soils by Bradyrhizobium japonicum inoculation. Nat. Clim. Change 3, 208-212.

Jeanneret, P., Baumgartner, D.U., Freiermuth, R., Gaillard, G., 2006. Méthode d'évaluation de l'impact des activités agricoles sur la biodiversité dans les bilans écologiques. Agroscope FAL Reckenholz. Pp. 67.

Jennersten, O., 1984. Flower visitation and pollination efficiency of some north European butterflies. Oecologia, 63, 80-89.

Jensen, C.R., Joernsgaard, B., Andersen, M.N., Christiansen, J.L., Mogensen, V.O., Friis, P., Petersen, C.T., 2004. The effect of lupins as compared with peas and oats on the yield of the subsequent winter barley crop. Eur. J. Agron. 20, 405-418.

Jensen, E. 1996. Grain yield, symbiotic $\mathrm{N}_{2}$ fixation and interspecific competition for inorganic $\mathrm{N}$ in pea-barley intercrops. Plant Soil 182, 25-38

Jensen, E.S., 1997. The role of grain legume $\mathrm{N}$ fixation in the nitrogen cycling of temperate cropping systems. Roskilde, Risø National Laboratory.

Jensen, E.S., Haahr, V., 1990. The effects of pea cultivation on succeeding winter cereals and winter oilseed rape nitrogen nutrition. Appl. Agric. Res. 5, 102-107.

Jensen, E.S., Hauggaard-Nielsen, H., 2003. How can increased use of biological $\mathrm{N}_{2}$ fixation in agriculture benefit the environment? Plant Soil 252, 177-186.

Jensen, E.S., Peoples, M.B., Hauggaard-Nielsen, H., 2010. Faba bean in cropping systems. Field Crop Res. 115, 203-216.

Jeuffroy, M.H, Baranger, E., Carrouée, B., de Chezelles, E., Gosme, M., Hénault, C., Schneider, A., Cellier, P., 2013. Nitrous oxide emissions from crop rotations including wheat, oilseed rape and dry peas. Biogeosciences 10, 1787-1797. 
Jezierny, D., Mosenthin, R., Bauer, E., 2010. The use of grain legumes as a protein source in pig nutrition: A review. Anim. Feed Sci. Technol. 157, 111-128.

Jiang, Z., Pulkkinen, M., Wang, Y., Lampi, A.-M., Stoddard, F.L., Salovaara, H., Piironen, V., Sontag-Strohm, T. 2016. Faba bean flavour and technological property improvement by thermal pre-treatments. LWT - Food Sci. Tech. 68, 295-305.

Johnson, S.K., Chua, V., Hall, R.S., Baxter, A.L., 2006. Lupin kernel fibre foods improve bowel function and beneficially modify some putative faecal risk factors for colon cancer in men. Brit. J. Nutr. 95, 372-378.

Jones, C.M., Spor, A., Brennan, F.P., Breuil, M.C., Bru, D., Lemanceau, P., Griffiths, B., Hallin, S., Philippot, L. 2014. Recently identified microbial guild mediates soil N2O sink capacity. Nature Climate Change 4, 801-805.

Justus, M., Köpke, U., 1995. Strategies to reduce nitrogen losses via leaching and to increase precrop effects when growing faba beans. Biol. Agric. Hortic. 11, 145-155.

Kautz, T., Perkons, U., Athmann, M., Pude, R., Köpke, U., 2013. Barley roots are not constrained to large-sized biopores in the subsoil of a deep Haplic Luvisol. Biol. Fert. Soils 49, 959-963.

Kayser, M., Müller, J., Isselstein, J., 2010. Nitrogen management in organic farming: comparison of crop rotation residual effects on yield, $\mathrm{N}$ leaching and soil conditions. Nutr. Cycl. Agroecosyst. 87, 21-31.

Keneni, G., Bekele, E., Getu, E., Imtiaz, M., Damte, B. M., Dagne, K., 2011. Breeding food legumes for resistance to storage insect pests: potential and limitations. Sustainability 3, 1399-1415.

Khalili, H., Kuusela, E., Suvitie, M., Huhtanen, P., 2002. Effect of protein and energy supplements on milk production in organic farming. Anim. Feed. Sci. Technol. 98, 103-119.

Khorasani, G. R., Okine, E.K., Corbett, R.R., Kennelly, J.J., 2001. Nutritive value of peas for lactating dairy cattle. Can. J. Anim. Sci. 81, 541-551.

Kirkegaard, J.A., Christen, O., Krupinsky, J., Layzell, D., 2008. Break crop benefits in temperate wheat production. Field Crop Res. 107, 185-195.

Knight, J D., 2012. Frequency of field pea in rotations impacts biological nitrogen fixation. Can. J. Plant Sci. 92, 1005-1011.

Knudsen, M., Meyer-Aurich, A., Olesen, J., Chirinda, N., Hermansen, J., 2014. Carbon footprints of crops from organic and conventional arable crop rotations - using a life cycle assessment approach. J. Clean. Prod. 64, 609-618.

Krogdahl, Å., Gajardo, K., Kortner, T.M., Penn, M., Gu, M., Berge, G.M., Bakke, A.M., 2015. Soya saponins induce enteritis in Atlantic salmon (Salmo salar L.). J. Agric. Food Chem. 63, 3887-3902.

La Favre, J.S., Focht, D.D., 1983. Conservation in soil of $\mathrm{H}_{2}$ liberated from $\mathrm{N}_{2}$ fixation by Hup- nodules. Appl. Env. Micro. 46, 304-311.

Lamminen, M., Kokkonen, T., Halmemies-Beauchet-Filleau, A., Termonen, T., Vanhatalo, A., Jaakkola, S., 2015. Partial replacement of grass silage with faba bean whole crop silage in the diet of dairy cows. Grassland and forages in high output dairy farming systems. Grassl. Sci. Eur. 20, 446-448.

Larsen, M., Lund, P., Weisbjerg, M. R., Hvelplund, T., 2009. Digestion site of starch from cereals and legumes in lactating dairy cows. Anim. Feed Sci. Technol. 153, 236-248.

Larsson, M., Granstedt, A., 2010. Sustainable governance of the agriculture and the Baltic Sea - agricultural reforms, food production and curbed eutrophication. Ecol. Econom. 69, 1943-1951.

Lassaletta, L., Billen, G., Romero, E., Garnier, J., Aguilera, E., 2014. How changes in diet and trade patterns have shaped the $\mathrm{N}$ cycle at the national scale: Spain (19612009). Reg. Environ. Change 14, 785-797.

Laudadio, V., Tufarelli, V., 2010. Treated fava bean (Vicia faba var. minor) as substitute for soybean meal in diet of early phase laying hens: egg-laying performance and egg quality. Poultry Sci. 89, 2299-2303. 
Laudicina, V.A., Novara, A., Gristina, L., Badalucco, L., 2014. Soil carbon dynamics as affected by long-term contrasting cropping systems and tillages under semiarid Mediterranean climate. Appl. Soil Ecol. 73, 140-147.

Lauk, R., Lauk, E., 2008. Pea-oat intercrops are superior to pea-wheat and pea-barley intercrops. Acta Agr. Scand. B-S P 58, 139-144.

Lawson, H.M., Topham, P.B. 1985. Competition between annual weeds and vining peas grown at a range of population densities: effects on the weeds. Weed Res. 25, 221229.

Lee, Y.P., Mori, T.A., Puddey, I.B., Sipsas, S., Ackland, T.R., Beilin, L.J., Hodgson, J.M., 2009. Effects of lupin kernel-enriched bread on blood pressure: a controlled intervention study. Am. J. Clin. Nutr. 89, 766-772.

Leithold, G., Hülsbergen, K.J., Michel, D., Schönmeier, H., 1997. Humusbilanzierung Methoden und Anwendungen als Agrar-Umweltindikator. Schriftenreihe der Sächsischen Landesanstalt für Landwirtschaft 3, 19-28.

Li, L., Sun, J., Zhang, F., Guo, T., Bao, X., Smith, F.A., Smith, S.E., 2006 Root distribution and interactions between intercropped species. Oecologia 147, 280-290.

Li, L., Li, S.-M., Sun, J.H., Zhou, L.-L., Bao, X.-G., Zhang, H.-G., Zhang, F.-S., 2007. Diversity enhances agricultural productivity via rhizosphere phosphorus facilitation on phosphorus-deficient soils. Proc. Natl. Acad. Sci. U.S.A 104, 11192-11196.

$\mathrm{Li}, \mathrm{X}$., Petersen, S., Sørensen, P., Olesen, J., 2015. Effects of contrasting catch crops on nitrogen availability and nitrous oxide emissions in an organic cropping system. Agric. Ecosyst. Environ. 199, 382-393.

Liebman, M., Robichaux, R.H., 1990. Competition by barley and pea against mustard: effects on resource acquisition, photosynthesis and yield. Agric. Ecosyst. Environ. 31, 155-172.

Lindström, K., Mousavi, S.A., 2010. Rhizobium and other N-fixing symbioses. symbioses. In: Encyclopedia of life science (ELS), John Wiley \& Sons, Ltd., Chichester. DOI: $10.1002 / 9780470015902 . a 0021157$

Link, W., 2006. Methods and objectives in faba bean breeding. In: Avila, C.m., Cubero, J.I., Moreno, M.T., Suso, M.J., Torres, A.M. (Eds.). Faba Bean Junta de Andalucía, Sevilla, Spain, pp. 35-40.

Lipiec, J., Simota, C., 1994. Crop responses in Central and Eastern Europe. In: Soane, B.D., van Ouwerkerk, C. (Eds.). Soil Compaction in Crop Production Elsevier, Amsterdam, pp. 365-389.

Lithourgidis, A.S., Dordas, C.A., Damalas, C.A., Vlachostergios, D.N., 2011. Annual intercrops: an alternative pathway for sustainable agriculture. Aust. J. Crop Sci. 5, 396-410.

Lizarazo, C.I., Yli-Halla, M., Stoddard, F.L., 2015. Pre-crop effects on the nutrient composition and utilization efficiency of faba bean (Vicia faba L.) and narrow-leafed lupin (Lupinus angustifolius L.). Nutr. Cycl. Agroecosys. 103, 311-327.

Lohaus, K., Vidal, S. 2010. Abundance of Sitona lineatus L. (Col, Curculionidae) in peas (Pisum sativum L.): Effects on yield parameters and nitrogen balance. Crop Prot. 29, 283-289.

López-Bellido, L., Fuentes, M., Castillo, J.E., López-Garrido, F.J., 1998. Effects of tillage , crop rotation and nitrogen fertilization on wheat-grain quality grown under rainfed Mediterranean conditions. Field Crop Res. 57, 265-276.

López-Bellido, L., López-Bellido, R.J., Castillo, J.E., López-Bellido, F.J., 2001. Effects of long-term tillage, crop rotation and nitrogen fertilization on bread-making quality of hard red spring wheat. Field Crop Res. 72, 197-210.

López-Bellido, R.J., López-Bellido, L., 2001. Efficiency of nitrogen in wheat under Mediterranean conditions: effect of tillage, crop rotation and $\mathrm{N}$ fertilization. Field Crop Res. 71, 31-46.

Luetke-Entrup, N., Schneider, M., Stemann, G., Gröblinghoff, F.-F., Heißen-huber, A., Pahl, H., Hülsbergen, K.-J., Maidl, F.X., Herr, H., Sommer,C., Korte, K., Brunotte, J., 
Kreye, H., Lindwedel, V., Zieseniß, H., Gien-app, C., Schulz, R.R., Propp, J., 2006. Bewertung von neuen Systemender Bodenbewirtschaftung in erweiterten Fruchtfolgen mit Körnerraps undKörnerleguminosen. Abschlussbericht über die Versuchsjahre 2001-2005. Fach-hochschule Südwestfalen, Fachbereich Agrarwirtschaft, Soest, pp. 215.

Lugtenberg, B., Kamilova, F., 2009. Plant-Growth-Promoting Rhizobacteria. Annu. Rev. Microbiol. 63, 541-56

Luke, 2016. Feed tables and nutrient requirements. [online]. Jokioinen: Natural Resources Institute Finland. http://www.mtt.fi/feedtables [29/09/2016]

Lupwayi, N.Z., Kennedy, A.C. 2007. Grain legumes in Northern Great Plains: Impacts on selected biological soil processes. Agron. J. 99, 1700-1709.

Lupwayi, N.Z., Lafond, G.P., May, W.E., Holzapfel, C.B., Lemke, R.L., 2012. Intensification of Field Pea Production: Impact on Soil Microbiology. Agron. J. 104, 1189-1196.

Lupwayi, N.Z, Soon, Y.K., 2015. Carbon and Nitrogen Release from Legume Crop Residues for Three Subsequent Crops. Soil Sci. Soc. Am. J. 79, 1650-1659.

Lupwayi, N., Soon, Y.K. 2016. Soil microbial properties during decomposition of pulse crop and legume green manure residues in three consecutive subsequent crops." Can. J. Soil Sci. 96, 1-14.

MacWilliam S., Wismer M. \& Kulshreshtha S., 2014. Life cycle and economic assessment of Western Canadian pulse systems: The inclusion of pulses in crop rotations. Agricultural Systems, 123: 43-53.

Madsen, A., Osterballe, R., Mortensen, H.P., Bejerholm, C., Barton, P., 1990. The influence of feeds on meat quality of growing pigs. 1. Tapioca meal, dried skimmed milk, peas, rapeseed cake, rapeseed, conventional and naked oats. Beretning fra Statens Husdyrbrugsforsog (National Institute for Animal Science) No. 673. Copenhagen, Denmark.

Magrini, M.B., Anton, M., Cholez, C., Duc, G., Hellou, G., Jeuffroy, M.H., Meynard, J.M., Pelzer, E., Voisin, A.S., Walrand, S., 2016. Why are grain-legumes rarely present in cropping systems despite their environmental and nutritional benefits? Analyzing lock-in in the French agrifood system. Ecol. Econ. 126, 152-162.

Maimaiti, J., Zhang,Y., Yang, J., Cen, Y.-P., Layzell, D.B., Peoples, M., Dong, Z., 2007. Isolation and characterization of hydrogen-oxidizing bacteria induced following exposure of soil to hydrogen gas and their impact on plant growth. Environ. Microbiol. 9, 435-444.

Malézieux, E., Crozat, Y., Dupraz, C., Laurans, M., Makowski, D., Ozier-Lafontaine, H., Rapidel, B., de Tourdonnet, S., Valantin-Morison, M., 2009. Mixing plant species in cropping systems: concepts, tools and models. A review. Agron. Sust. Dev. 29, 4362.

Mariotti, M., Masoni, A., Ercoli, L., Arduini, L., 2015. Nitrogen leaching and residual effect of barley/field bean intercropping. Plant Soil Environ. 61, 60-65.

McCallum, M.H., Kirkegaard, J.A., Green, T.W., Cresswell, H.P., Davies, S.L., Angus, J.F., Peoples, M.B., 2004. Improved subsoil macroporosity following perennial pastures. Aust. J. Exp. Agric. 44, 299-307.

McDaniel, M.D., Tiemann, L.K., Grandy, A.S., 2014. Does agricultural crop diversity enhance soil microbial biomass and organic matter dynamics? A meta-analysis. Ecol. Appl. 24, 560-570.

McEwen J., Yeoman D.P., Moffitt R., 1988. Effect of seed rates, sowing dates and methods of sowing on autumn-sown field beans (Vicia faba L.), J. Agr. Sci. 110, 345-352.

McEwen, J., Darby, R.J., Hewitt, M.V., Yeoman, D.P., 1989. Effects of field beans,fallow, lupins, oats, oilseed rape, peas, ryegrass, sunflowers and wheat onnitrogen residues in the soil and on the growth of a subsequent wheat crop. J. Agric. Sci. 115, 209219. 
McKenzie, R.H., Middleton, A.B., Solberg, E.D., DeMulder, J., Fore, N., Clayton, B.W., Bremer, E. 2001. Response of pea to rhizobia inoculation and starter nitrogen in Alberta. Can. J. Plant Sci. 81, 637-643.

Millennium Ecosystem Assessment. 2005. Ecosystems and Human Well-Being: Synthesis. Island Press, Washington.

Mead, R., Willey, R.W. 1980, The concept of a 'Land Equivalent Ratio' and advantages in yields from intercropping. Exp. Agr. 16, 217-228.

Melero, S., López-Bellido, R.J., López-Bellido, L., Muñoz-Romero, V., Moreno,F., Murillo, J.M., 2011. Long-term effect of tillage, rotation and nitrogen fertiliser on soil quality in a Mediterranean Vertisol. Soil Tillage Res. 114, 97-107.

Meyer-Aurich, A., Weersink, A., Janovicek, K., Deen, W., 2006. Cost efficient rotation and tillage options to sequester carbon and mitigate GHG emissions from agriculture in Eastern Canada. Agric. Ecosyst. Environ. 117, 119-127.

Micek P., Kulig B., Woźnica P., Sajdak A., 2012. The nutritive value for ruminants of faba bean (Vicia faba) seeds and naked oat (Avena nuda) grain cultivated in an organic farming system. J. Anim. Feed Sci. 21, 773-786.

Mikkonen, A., 2012. The potential of microbial ecological indicators to guide ecosophisticated management of hydrocarbon-contaminated soils. Dissertationes Biocentri Viikki Universitatis Helsingiensis 22/2011. 63 pp. https://helda.helsinki.fi/bitstream/handle/10138/28750/thepoten.pdf?sequence $=1$ (Accessed 29/09/2016)

Molina-Poveda, C., Lucas, M., Jover, M. 2013. Evaluation of the potential of Andean lupin meal (Lupinus mutabilis Sweet) as an alternative to fish meal in juvenile Litopenaeus vannamei diets. Aquaculture 410/411, 148-156.

Möller, K., Stinner, W., Leithold, G., 2008. Growth, composition, biological N2 fixation and nutrient uptake of a leguminous cover crop mixture and the effect of their removal on field nitrogen balances and nitrate leaching risk. Nutr. Cycl. Agroecosyst. 82, 233249.

Möller, K., Reents, H.-J.. 2009. Effects of various cover crops after peas on nitrate leaching and nitrogen supply to succeeding winter wheat or potato crops. J. Plant Nutr. Soil Sci., 172, 277-287.

Moraine, M., Duru, M., Nicholas, P., Leterme, P., Therond, O., 2014. Farming system design for innovative crop-livestock integration in Europe. Animal 8, 1204-1217.

Moraine, M., Grimaldi, J., Murgue, C., Duru, M., Therond, O., 2016. Codesign and assessment of cropping systems for developing crop livestock integration at the territory level. Agric. Syst. 147, 87-97.

Muñoz-Romero, V., López-Bellido, L., López-Bellido, R.J., 2011. Faba bean root growth in a Vertisol: Tillage effects. Field Crop Res. 120, 338-344.

Murphy-Bokern, D., Kleeman, L. 2015. The role of corporate social responsibility in reducing greenhouse gas emissions from agriculture and food. A study for the International Food Policy Research Institute. www.murphy-bokern.com [30/10/2016]

Murphy-Bokern, D., Peeters, A., Westhoek, H. 2017. The role of legumes in bringing protein to the table. In: Murphy-Bokern, D., Stoddard, F., Watson, C. (Eds.) Legumes in Cropping Systems. CABI, Oxon (In press).

Myhre, G., Shindell, D., Bréon, F.M., Collins, W., Fuglestvedt, J., Huang, J., Koch, D., Lamarque, J.F., Lee, D., Mendoza, B., Nakajima, T., Robock, A., Stephens, G., Takemura, T., Zhang, H. 2013, Anthropogenic and natural radiative forcing. In: Stocker, T.F., Qin, D., Plattner, G.K., Tignor, M., Allen, S.K., Boschung, J., Nauels, A., Xia, Y., Bex, V., Midgley, P.M. (Eds.) Climate Change 2013: The Physical Science Basis. Contribution of Working Group I to the Fifth Assessment Report of the Intergovernmental Panel on Climate Change, Cambridge University Press, Cambridge, UK. 
Nalle, C.L., Ravindran, G., Ravindran, V., 2010. Influence of dehulling on the apparent metabolisable energy and ileal amino acid digestibility of grain legumes for broilers. J. Sci. Food Agric. 90, 1227-1231.

Naudin, C., Corre-Hellou, G., Pineau, S., Crozat, Y., Jeuffroy, M.H., 2010. The effect of various dynamics of $\mathrm{N}$ availability on winter pea-wheat intercrops: crop growth, $\mathrm{N}$ partitioning and symbiotic $\mathrm{N}_{2}$ fixation. Field Crop Res. 119, 2-11.

Naudin, C., van der Werf, H., Jeuffroy, M-H., Corre-Hellou, G., 2014. Life cycle assessment applied to pea-wheat intercrops: A new method for handling the impacts of coproducts. J. Clean. Prod. 73, 80-87.

Nemecek, T., von Richthofen, J.-S ., Dubois, G., Casta, P., Charles, R., Pahl, H., 2008. Environmental impacts of introducing grain legumes into european crop rotations. Eur. J. Agron. 28, 380-393.

Nemecek, T., Weiler, K., Plassmann, K., Schnetzer, J., Gaillard, G., Jefferies, D., GarcíaSuárez, T., King, H., Milà i Canals, L., 2012. Estimation of the variability in global warming potential of worldwide crop production using a modular extrapolation approach. J. Clean. Prod. 31, 106-117.

Nemecek, T., Hayer, F., Bonnin, E., Carrouee, B., Schneider, A., Vivier, C., 2015. Designing eco-efficient crop rotations using life cycle assessment of crop combinations. Eur. J. Agron. 65, 40-51.

Neugschwandtner, R.W., Wagentristl, H., Kaul, H.-P., 2014. Nitrogen concentrations and nitrogen yield of above-ground dry matter of chickpea during crop growth compared to pea, barley and oat in Central Europe. Turk. J. Field Crops. 19, 136-141.

Neumann, A., Schmidtke, K., Rauber, R., 2007. Effects of crop density and tillage system on grain yield and $\mathrm{N}$ uptake from soil and atmosphere of sole and intercropped pea and oat. Field Crop Res. 100, 285-293.

Neumann, A., Werner, J., Rauber, R., 2009. Evaluation of yield-density relationships and optimization of intercrop compositions of field-grown pea-oat intercrops using the replacement series and the response surface design. Field Crop Res. 114, 286-294.

Neumann, A., Torstensson, G., Aronsson, H., 2011. Losses of nitrogen and phosphorus via the drainage system from organic crop rotations with and without livestock on a clay soil in southwest Sweden. Org. Agric. 1, 217-229.

Nguyen T.T.H., Bouvarel I., Ponchant P. \& Van Der Werf H.M.G., 2012. Using environmental constraints to formulate low-impact poultry feeds. J. Clean. Prod. 28, 215-224.

Obbard, J.P., Jones, K.C., 2001. Measurement of symbiotic nitrogen-fixation in leguminous host-plants grown in heavy metal-contaminated soils amended with sewage sludge. Environ. Pollut. 111, 311-320.

Oberson, A., Nanzer, S., Bosshard, C., Dubois, D., Mäder, P., Frossard, E., 2007. Symbiotic $\mathrm{N}_{2}$ fixation by soybean in organic and conventional cropping systems estimated by ${ }^{15} \mathrm{~N}$ dilution and ${ }^{15} \mathrm{~N}$ natural abundance. Plant Soil 290, 69-83.

O'Hara, G.W., Boonkerd, N., Dilworth, M.J., 1988. Mineral constraints to nitrogen fixation. Plant Soil 108, 93-110.

Osborne, S.L., Riedell, W.E. 2011. Impact of low rates of nitrogen applied at planting on soybean nitrogen fixation. J. Plant Nutr. 34, 436-448.

Österman, J., Mousavi, S.A., Koskinen, P., Paulin, L., Lindström, K., 2015. Genomic features separating ten strains of Neorhizobium galegae with different symbiotic phenotypes. BMC Genomics 16, 348.

Palmer, R., Perez, P., Ortiz-Perez, E., Maalouf, F., Suso, M., 2009. The role of croppollinator relationships in breeding for pollinator-friendly legumes: from a breeding perspective. Euphytica 170, 35-52.

Pan, P., Qin, Y., 2014. Genotypic diversity of soybean in mixed cropping can affect the populations of insect pests and their natural enemies. Int. J. Pest Manage. 60, 287292. 
Panse, A., Maidl, F.X., Dennert, J., Brunner, H., Fischbeck, G., 1994. Yieldformation in cereal-rich crop rotations and monocultures in an extensive and intensive cropmanagement system. J. Agron. Crop Sci. 173,160-171.

Paolini, R., Caporali, F., Campigliae, E., 1993. Yield response,complementarity and competitive ability of bread wheat (Triticum aestivum L.) and pea (Pisum sativum L.) in mixture. Agricoltura Mediterranea 123, 114-121.

Papastylianou, I., 2004. Effect of rotation system and $\mathrm{N}$ fertiliser on barleyand vetch grown in various crop combinations and cycle lengths. J. Agric.Sci. 142, 41-48.

Pappa, V.A, Rees, R.M., Walker, R.L., Baddeley, J.A., Watson, C.A., 2012. Intercropping: effect on yield and $\mathrm{N}$ balances in a three year crop rotation. J. Agric. Sci., Camb. 150, 584-594.

Pappa, V.A., Rees, R.M., Walker, R.L., Baddeley, J.A., Watson, C.A., 2011. Nitrous oxide emissions and nitrate leaching in an arable rotation resulting from the presence of an intercrop. Agric. Ecosyst. Environ. 141, 153-161.

Peltonen-Sainio, P., Niemi, J.K., 2012. Protein crop production at the northern margin of farming: to boost or not to boost. Agric. Food Sci. 21, 370-383.

Pelzer, E., Hombert, N., Jeuffroy, M.H., Makowski, D., 2014. Meta-analysis of the effect of nitrogen fertilization on annual cereal-legume intercrop production. Agron. J. 106,1775-1786.

Pelzer, E., Bazot, M., Makowski, D., Corre-Hellou, G., Naudin, C., Al Rifaï, M., Baranger, E., Bedoussac, L., Biarnès, V., Boucheny, P., Carrouée, B., Dorvillez, D., Foissy, D., Gaillard, B., Guichard, L., Mansard, M.C., Omon, B., Prieur, L., Yvergniaux, M., Justes, E., Jeuffroy, M.H., 2012. Pea-wheat intercrops in low-input conditions combine high economic performances and low environmental impacts. Eur. J. Agron. 40, 39-53.

Peoples, M.B., Brockwell, J., Herridge, D.F., Rochester, I.J., Alves, B.J.R. , Urquiaga, S., Boddey, R.M., Dakora, F.D., Bhattarai, S., Maskey, S.L., Sampet, C., Rerkasem, B., Khan, D.F., Hauggaard-Nielsen, H., Jensen, E.S., 2009. The contributions of nitrogen-fixing crop legumes to the productivity of agricultural systems. Symbiosis, $48,1-17$.

Petit, H.V., Rioux, R., Ouellet, Q.R., 1997. Milk production and intake of lactating cows fed raw or extruded peas. J. Dairy Sci. 80, 3377-3385.

Peyraud, J.L., Taboada, M., Delaby, L., 2014. Integrated crop and livestock systems in Western Europe and South America: a review. Eur. J. Agron. 57, 31-42.

Pfender, W.F. \& Hagedorn, D.J. (1985). Aphanomyces as a component of the bean root rot complex in Wisconsin. Ann. Rep. Bean Improve. Coop., 24, 125.

Piesse, J., Thirtle, C., 2009. Three bubbles and a panic: An explanatory review of recent food commodity price events. Food Policy 34,119-129.

Pilorge, E., Muel, F. 2016. What vegetable oils and proteins for 2030 ? Would the protein fraction be the future of oil and protein crops? OCL 23, D402.

Plaza-Bonilla, D., Nolot, J-M., Raffaillac, D., Justes, E., 2015. Cover crops mitigate nitrate leaching in cropping systems including grain legumes: field evidence and model simulations. Agriculture, Ecosystems and Environment 212,1-12.

Podgorska-Lesiak, M., Sobkowicz, P., 2013. Prevention of pea lodging by inter-cropping barley with peas at different nitrogen fertilisation levels. Field Crop Res. 149, 95-104.

Poggio, S.L., 2005. Structure of weed communities occurring in monoculture and intercropping of field pea and barley. Agric. Ecosyst. Environ. 109, 48-58.

Potts, D. 2003. The myth of the overwintered stubble: New government schemes are not properly designed to recover lost farm biodiversity. Bird Study 50, 91-93.

Preissel, S., Reckling, M., Bachinger, J., Zander, P. 2017. Introducing legumes into European cropping systems: farm-level economic effects. In: Murphy-Bokern, D., Stoddard, F., Watson, C. (Eds.) Legumes in Cropping Systems. CABI, Oxon (In press). 
Preissel, S., Reckling, M., Schläfke, N., Zander, P., 2015. Magnitude and farm-economic value of grain legume pre-crop benefits in Europe: A review. Field Crop Res. 175, 6479.

Prew, R.D., Dyke, G.V.,1979. Experiments comparing break crops as a preparation for winter-wheat followed by spring barley. J. Agric. Sci. 92, 189-201.

PROLEA, 2011. Statistiques des oléagineux et protéagineux. Edition 2010-2011.

Puhakka, L., Jaakkola, S., Kokkonen, T., Vanhatalo, A., 2014. Comparison of faba bean and rapeseed meal protein supplements in grass-silage based cow diets. Harnessing the Ecology and Physiology of Herbivores, eds S. Hatcher, G.L. Krebs, B.V.B. Holman. Proc. Aust. Soc. Anim. Prod. 2014, 30, 235. ISSN 0728-5965

Puhakka, L., Jaakkola, S., Simpura, I., Kokkonen, T., Vanhatalo, A., 2016. Effects of replacing rapeseed meal with fava bean at 2 concentrate crude protein levels on feed intake, nutrient digestion, and milk production in cows fed grass silage-based diets. J. Dairy Sci. 99, 7993-8006.

Pursiainen, P., Tuori, T., 2006. Replacing grass silage with pea-barley intercrop silage in the feeding of the dairy cow. Agric. Food Sci.15, 235-251.

Ramin, M. Höjer, A., Fogelberg, F, Hetta, M., Huhtanen, P. 2015. Effect of heat treated field beans on the performance of Swedish lactating dairy cows. Proceedings of the 6th Nordic Feed Science Conference pp. 111-115. Available from http://www.slu.se/en/departments/animal-nutrition-management/news/nordic-feedscience-conference-2016/contributions-nfsc-2016/

Rasse, D., Rumpel, C., Dignac, M.-F., 2005. Is soil carbon mostly root carbon? Mechanisms for a specific stabilisation. Plant Soil 269, 341-356.

Rauber, R., Schmidtke, K., Kimpel-Freund, H., 2001. The performance of pea (Pisum sativum L.) and its role in determining yield advantages in mixed stands of pea and oat (Avena sativa L.). J. Agron. Crop Sci. 187, 137-144.

Reckling, M., Döring, T., Stein-Bachinger, K., Bloch, R., Bachinger, J., 2015. Yield stability of grain legumes in an organically managed monitoring experiment. Asp. Appl. Biol. $128,57-62$.

Reckling, M., Bergkvist, G., Watson, C.A., Stoddard, F.L., Zander, P.M., Walker, R., Pristeri, A., Toncea, I., Bachinger, J., 2016a. Trade-offs between economic and environmental impacts of introducing legumes into cropping systems. Frontiers Plant Sci 7, 669. http://dx.doi.org/10.3389/fpls.2016.00669

Reckling, M., Hecker, J.-M., Bergkvist, G., Watson, C., Zander, P., Stoddard, F., Eory, V., Topp, K., Maire, J., Bachinger, J., 2016b. A cropping system assessment framework - evaluating effects of introducing legumes into crop rotations. Eur. J. Agron. 76, 186197.

Reckling, M., Bergkvist, G., Bloch, R., Stoddard, F.L., Watson, C.A., and Bachinger, J. (2016c). Novel approaches to optimize grain legume cropping systems. Asp. Appl. Biol. 133 (In press).

Reckmann, K., Blank, R., Traulsen, I., Krieter, J., 2016. Comparative life cycle assessment (LCA) of pork using different protein sources in pig feed. Archiv Tierzucht, 59, 27-36.

Rees, R.M., Baddeley, J.A., Bhogal, A., Ball, B.C., Chadwick, D.R., MacLeod, M, Lilly, A., Pappa, V., Thorman, R.E., Watson, C.A., Williams, J.R., 2013. Nitrous oxide mitigation in UK agriculture. Soil Sci. Plant Nut. 59, 3-15.

Robson, M.C., Fowler, S.M., Lampkin, N.H., Leifert, C., Leitch, M., Robinson, D., Watson, C.A., Litterick, A.M., 2002. The agronomic and economic potential of break crops for ley/arable rotations in temperate organic agriculture. Adv. Agron. 77, 369-427.

Rochester, I.J., Peoples, M.B., Hulugalle, N.R., Gault, R.R., Constable, G.A., 2001. Using legumes to enhance nitrogen fertility and improve soil condition in cotton cropping systems. Field Crop Res. 70, 27-41.

Rochette, P., Janzen, H.H., 2005. Towards a revised coefficient for estimating $\mathrm{N}_{2} \mathrm{O}$ emissions from legumes. Nutr. Cycl. Agroecosys. 73,171-179. 
Rondahl, T., Bertilsson, J., Martinsson, K.. 2007. Mixing whole-crop pea-oat silage and grass-clover silage: positive effects on intake and milk production of dairy cows. Grass Forage Sci. 62, 459-469.

Rose, T.J., Damon, P. and Rengel, Z., 2010. Phosphorus-efficient faba bean (Vicia faba L.) genotypes enhance subsequent wheat crop growth in an acid and an alkaline soil. Crop Pasture Sci. 61,1009-1016.

Rubiales, D., Fernández-Aparicio, M., 2012. Innovations in parasitic weeds management in legume crops. A review. Agron. Sustain. Dev. 32, 433-449.

Rubiales, D., Fernández-Aparicio, M., Pérez-de-Luque, A., Prats, E., Castillejo, M.A., Sillero, J.C., Rispail, N., Fondevilla, S., 2009. Breeding approaches for crenate broomrape (Orobanche crenata Forsk.) management in pea (Pisum sativum L.). Pest Manag. Sci. 65, 553-559.

Rubiales, D., Fondevilla, S., Chen, W., Gentzbittel, L., Higgins, T.J.V., Castillejo, M.A., Singh, K.B., Rispail, N., 2015. Achievements and challenges in legume breeding for pest and disease resistance. Crit. Rev. Plant Sci. 14, 1-42.

Russelle, M.P., Entz, M.H., Franzluebbers, A.J., 2007. Reconsidering integrated croplivestock systems in North-America. Agron. J. 99, 325-334.

Sabais, A.C.W., Scheu, S., Eisenhauer, N. 2011. Plant species richness drives the density and diversity of Collembola in temperate grassland. Acta Oecol. 37,195-202.

Sadok, W., Angevin, F., Bergez, J.-E., Bockstaller, C., Colomb, B., Guichard, L., Reau, R., Messéan, A., Doré, T. (2009). MASC, a qualitative multi-attribute decision model for ex ante assessment of the sustainability of cropping systems. Agron. Sust. Dev. 29, 447-461.

Saini, V.K., Bhandari, S.C., Tarafdar, J.C., 2004. Comparison of crop yield, soil microbial C, $\mathrm{N}$ and $\mathrm{P}, \mathrm{N}$-fixation, nodulation and mycorrhizal infection in inoculated and noninoculated sorghum and chickpea crops. Field Crop Res. 89, 39-47.

Salvagiotti, F, Cassman, K.G., , J.E., Walters, D.T., Weiss, A., , A., 2008. Nitrogen uptake, fixation and response to fertilizer $\mathrm{N}$ in soybeans: A review. Field Crop Res. 108, 1-13.

Sanz-Cobena, A., García-Marco, S., Quemada, M., Gabriel, J., Almendros, P., Vallejo, A., 2014. Do cover crops enhance $\mathrm{N}_{2} \mathrm{O}, \mathrm{CO}_{2}$ or $\mathrm{CH}_{4}$ emissions from soil in Mediterranean arable systems? Sci. Total Environ. 466-467, 164-174.

Sasu-Boakye, Y., Cederberg, C., Wirsenius, S., 2014. Localising livestock protein feed production and the impact on land use and greenhouse gas emissions. Animal, 8, 1339-1348.

Scalbert, A., Manach, C., Morand, C., Remesy, C., Jimenez, L., 2005. Dietary polyphenols and the prevention of diseases. Crit. Rev. Food Sci. 45, 287-306.

Scalise, A., Tortorella, D., Pristeri, A., Petrovicová, B., Gelsomino, A., Lindström, K., Monti, M., 2015. Legume-barley intercropping stimulates soil $\mathrm{N}$ supply and crop yield in the succeeding durum wheat in a rotation under rainfed conditions. Soil Biol. Biochem. 89, 150-161.

Schäfer, B.C., 2003. Probleme und Risiken von wintergetreide- und/oder weizenbetonten Anbaufolgen. In: Schäfer, B.C. (Ed.), "Weizenbetonte Fruchtfolgen - Probleme und Alternativen. Fachtagung an der Fachhochschule Südwestfalen" pp. 2-15.

Schätzl, R. and Halama, M. (2013). Micro economics of soya production - soya bean cultivation under the aspect of crop rotation and economy. Danube Soya Congress in 2013 in Augsberg Germany. http://www.donausoja.org/fileadmin/user_upload/DS_Congress/Congress_2013/Pres entations_2013/Day_1_Forum_I/Schaetzl_HalamaMicro_Economics_of_Soya_Production_DS2013.pdf

Schilizzi, S.G.M., Kingwell, R.S., 1999. Effects of climatic and price uncertainty on the value of legume crops in a Mediterranean-type environment. Agric. Syst. 60, 55-69.

Schmidtke, K., Neumann, A., Hof, C., Rauber, R., 2004. Soil and atmospheric nitrogen uptake by lentil (Lens culinaris Medik.) and barley (Hordeum vulgare ssp. nudum L.) as monocrops and intercrops. Field Crop Res. 87, 245-256. 
Schouls, J., Langelaan, J.G., 1994. Lodging and yield of dry peas (Pisum sativum L.) as influenced by various mixing ratios of a conventional and a semi-leafless cultivar. J. Agron. Crop Sci. 172, 207-214.

Schröder, D., Köpke, U., 2012. Faba bean (Vicia faba L.) intercropped with oil crops-a strategy to enhance rooting density and to optimize nitrogen use and grain production? Field Crop Res. 135, 74-81.

Schweiger, P., Hofer, M., Hartl, W., Wanek, W., Vollmann, J., 2012. $\mathrm{N}_{2}$ fixation by organically grown soybean in Central Europe: Method of quantification and agronomic effects. Eur. J. Agron. 41, 11-17.

Schwenke, G.D, Herridge, D.F., Scheer, C., Rowlings, D.W., Haigh, B.M., McMullen, K., 2015. Soil $\mathrm{N}_{2} \mathrm{O}$ emissions under $\mathrm{N}_{2}$-fixing legumes and $\mathrm{N}$-fertilised canola: $A$ reappraisal of emissions factor calculations. Agric. Ecosyst. Environ. 202, 232-242.

Si, P., Buirchell, B., Sweetingham, M., 2009. Improved metribuzin resistance in narrowleafed lupin (Lupinus angustifolius L.) by induced mutation and field selection. Field Crop Res. 113, 282-286.

Sirtori, C.R., Galli, C., Anderson, J.W., Arnoldi, A., 2009. Nutritional and nutraceutical approaches to dyslipidemia and atherosclerosis prevention: Focus on dietary proteins. Atherosclerosis 203, 8-17.

Sirtori, C.R., Triolo, M., Bosisio, R., Bondioli, A., Calabresi, L., De Vergori, V., Gomaraschi, M., Mombelli, G., Pazzucconi, F., Zacherl, C., Arnoldi, A., 2012. Hypocholesterolaemic effects of lupin protein and pea protein/fibre combinations in moderately hypercholesterolaemic individuals. Brit. J. Nutr. 107, 1176-1183.

Skoufogianni, E., Danalatos, N.G., Dimoyiannis, D., Efthimiadis, P., 2013. Effects of pea cultivation as cover crop on nitrogen-use efficiency and nitrogen uptake by subsequent maize and sunflower crops in a sandy soil in Central Greece. Commun. Soil Sci. Plant Anal. 44, 861-868.

Soldevilla-Martinez, M., Martin-Lammerding, D., Tenorio, J.L., Walter, I., Quemada, M., Lizaso, J.I., 2013. Simulating improved combinations tillage-rotation under dryland conditions. Span. J. Agric. Res. 11, 820-832.

Smith, L.A., Houdijk, J.G.M., Homer, D., Kyriazakis, I., 2013. Effects of dietary inclusion of pea and faba bean as a replacement for soybean meal on grower and finisher pig performance and carcass quality. J. Anim. Sci. 91, 3733-3741.

Song, Y.N., Zhang, F.S., Marschner, P., Fan, F.L., Gao, H.M., Bao, X.G., Sun,J.H., Li, L., 2007. Effect of intercropping on crop yield and chemical and microbiological properties in rhizosphere of wheat (Triticum aestivum L.), maize (Zea mays L.), and fababean (Vicia faba L.). Biol. Fert. Soils 43, 565-574.

Spies, J.M., Warkentin, T.D., Shirtliffe, S.J., 2011. Variation in Field Pea (Pisum sativum) Cultivars for Basal Branching and Weed Competition. Weed Sci. 59, 218-223.

Statistik Austria, 2010. AS2010 bodenbedeckung im winter nach politischen bezirken. In: Agrarstrukturerhebung 2010.

Stephany, M., Eckert, P., Bader-Mittermaier, S., Schweiggert-Weisz, U., Carle, R. 2016. Lipoxygenase inactivation kinetics and quality-related enzyme activities of narrowleafed lupin seeds and flakes. LWT - Food Sci. Tech. 68, 36-43.

Stevenson, F.C., van Kessel, C., 1997. Nitrogen contribution of pea residue in a hummocky terrain. Soil Sci. Soc. Am. J. 61, 494-503.

Stoddard, F., Hovinen, S., Kontturi, M., Lindström, K., Nykänen, A., 2009. Legumes in Finnish agriculture: history, present status and future prospects. Agric. Food Sci. 18, 191-205.

Stoddard, F.L., Bond, D.A., 1987. The pollination requirements of the faba bean (Vicia faba L.). Bee World 68,144-152.

Stoddard, F.L., Nicholas, A.H., Rubiales, D., Thomas, J.,Villegas-Fernández, A.M., 2010. Integrated pest management in faba bean. Field Crop Res. 115, 308-318. 
Strohle, A., Waldmann, A., Wolters, M., Hahn, A., 2006. Vegetarian nutrition: Preventive potential and possible risks part 1: Plant foods. Wiener Klinische Wochenschrift 118, 580-593.

Sulas, L., Canu, S., Ledda, L., Carroni, A.M., Salis, M., 2016. Yield and nitrogen fixation potential from white lupine grown in rainfed Mediterranean environments. Sci. Agr. 73, 338-346.

Supit, I., 1997. Predicting national wheat yields using a crop simulation and trend models. Agric. For. Met. 88, 199-214.

Szumigalski, A., Van Acker, R., 2005. Weed suppression and crop production in annual intercrops. Weed Sci. 53, 813-825.

Tacon, A.G.J., Hasan, M.R., Metian, M., 2011. Demand and supply of feed ingredients for farmed fish and crustaceans. Trends and prospects. FAO Fisheries and Aquaculture Technical Paper 564. Rome, Italy: Food and Agriculture Organization of the United Nations.

Tautges, N.E., Sullivan, T.S., Reardon, C.L., Burke, I.C., 2016. Soil microbial diversity and activity linked to crop yield and quality in a dryland organic wheat production system. Appl. Soil Ecol. 108, 258-268.

Thörning, G., Norli, H.R., Saucke, H., Knudsen, G.K., 2014. Pea plant volatiles guide host location behaviour in the pea moth. Arthropod-Plant Interact. 8, 109-122.

Thorup-Kristensen, K., 1993. Root growth of nitrogen catch crops and of a succeeding crop of broccoli. Acta Agr. Scand. B-S P 43, 58-64.

Tosti, G., Benincasa, P., Farneselli, M., Tei, F., Guiducci, M., 2014. Barley-hairy vetch mixture as cover crop for green manuring and the mitigation of $\mathrm{N}$ leaching risk. Eur. J. Agron. 54, 34-39.

Trabelsi, D., Ben Ammar, H., Mengoni, A., Mhamdi, R., 2012. Appraisal of the crop-rotation effect of rhizobial inoculation on potato cropping systems in relation to soil bacterial communities. Soil Biol. Biochem. 54, 1-6.

Tribouillois, H., Cohan, J-P., Justes, E. 2016. Cover crop mixtures including legume produce ecosystem services of nitrate capture and green manuring: assessment combining experimentation and modelling. Plant Soil 401, 347-364.

Trükmann, K., Reintam. E., Kuht J, Nugis, E.., Edesi L., 2008. Effect of soil compaction on growth of narrow-leafed lupine, oilseed rape and spring barley on sandy loam soil, Agron. Res. 6, 101-108.

Trushenski, J.T., Kasper, C.S., Kohler, C.C., 2006. Challenge and opportunities in finfish nutrition. N. Am. J. Aquacult. 68, 122-140.

Tufarelli, V.R., Khan, U., Laudadio, V., 2012. Evaluating the suitability of field beans as a substitute for soybean meal in early-lactating dairy cow: Production and metabolic responses. Anim. Sci. J. 83, 136-140.

Tuulos, A., Yli-Halla, M., Stoddard, F., Mäkelä, P., 2014 Winter turnip rape as a soil N scavenging catch crop in a cool humid climate. Agron. Sust. Dev. 35, 359-366.

Unkovich, M.J., Pate, J.S., 2000. An appraisal of recent field measurements of symbiotic $\mathrm{N}_{2}$ fixation by annual legumes. Field Crop Res. 65, 211-222.

US Soybean Export Council, 2016. Conversion table. http://ussec.org/resources/conversiontable/ [09/10/2016]

Van Kessel, C., Hartley, C., 2000. Agricultural management of grain legumes: has it led to an increase in nitrogen fixation? Field Crop Res. 65, 165-181.

Van der Pol, M., Hristov, A.N., Zaman, S., Delano, N., 2008. Peas can replace soybean meal and corn grain in dairy cow diets. J. Dairy Sci. 91, 698-703.

Vandermeer, J., 1989. The Ecology of Intercropping. Cambridge University Press, Cambridge.

van der Werf, H., Petit, J., Sanders, J., 2005. The environmental impacts of the production of concentrated feed: the case of pig feed in Bretagne. Agric. Syst. 83, 153-177. 
Vargas, A.A.T., Graham, P.H., 1988. Phaseolus vulgaris cultivar and Rhizobium strain variation in acid-pH tolerance and nodulation under acid conditions. Field Crop Res. 19, 91-101.

Venter, Z.S., Jacobs, K., Hawkins, H.J., 2016. The impact of crop rotation on soil microbial diversity: A meta-analysis. Pedobiologia 59, 215-223.

Vicenti, A., Toteda, F., Di Turi, L., Cocca, C., Perrucci, M., Melodia, L., Ragni, M., 2009. Use of sweet lupin (Lupinus albus L. var. Multitalia) in feeding for Podolian young bulls and influence on productive performances and meat quality traits. Meat Sci. 82, 247251.

Vocanson, A, Roger-Estrade, J., Boizard, H., Jeuffroy, M-H., 2006. Effects of soil structure on pea (Pisum sativum L.) root development according to sowing date and cultivar. Plant Soil 281,121-135.

Voisin A.S., Salon C., Munier-Jolain N.G., Ney B., 2002. Quantitative effects of soil nitrate, growth potential and phenology on symbiotic nitrogen fixation of pea (Pisum sativum L.). Plant Soil 243, 31-42.

Voisin, A.-S., Guéguen, J., Huyghe, C., Jeuffroy, M.-H., Magrini, M.-B., Meynard, J. M., Mougel, C., Pellerin, S., Pelzer, E. 2014. Legumes for feed, food, biomaterials and bioenergy in Europe: a review. Agron. Sust. Dev. 34, 361-380.

Von Richthofen, J.-S., Pahl, H., Bouttet, D., Casta, P., Cartrysse, C., Charles, R., and Lafarga, A., 2006a. What do European farmers think about grain legumes. Grain Legumes 45, 14-15. http://www.ias.csic.es/grainlegumesmagazine/ [5.11.2012].

Von Richthofen, J.-S., Pahl, H., Nemecek, T., 2006b. Economic interest of grain legumes in European crop rotations. GL-Pro. Deliverable, 3, p.58.

West, T.O., Post, W.M., 2002. Soil organic carbon sequestration rates by tillage and crop rotation: a global data analysis. Soil Sci. Soc. Am. J., 66, 1930-1946.

Westhoek, H., Rood, T., van de Berg, M., Janse, J., Nijdam, D., Reudink M, Stehfest E., 2011. The Protein Puzzle, The Hague: PBL Netherlands Environmental Assessment Agency.

Westphal, C., Steffan-Dewenter, I., Tscharntke, T., 2003. Mass-flowering crops enhance pollinator densities at a landscape scale. Ecol. Lett., 6, 961-965.

White, C.L., Staines, M. v-H., Phillips, N., Young, P., Coupar, F., Ashes, J.R., Gulati, S.K. 2004. Protected canola meal increases milk protein concentration in dairy cows fed a grass silage-based diet. Aust. J. Expt. Agric. 44, 827-832.

White, C.L., Staines, V.E., Staines, M.vH. 2007. A review of the nutritional value of lupins for dairy cows. Aust. J. Agric. Res. 58,185-202.

White, G.A., Smith, L.A., Houdijk, J.G.M., Homer, D., Kyriazakis, I., Wiseman, J., 2015. Replacement of soya bean meal with peas and faba beans ingrowing/finishing pig diets: effect on performance, carcass composition and nutrient excretion. Anim. Feed Sci. Technol. 209, 202-210.

Wilkins, R.J., Jones, R., 2000. Alternative home-grown protein sources for ruminants in the United Kingdom. Anim. Feed Sci. Technol. 85, 23-32.

Willey, R.W., 1979. Intercropping - Its Importance and research Needs. Part 1. Competition and Yield Advantages. Field Crop Abstr. 32, 1-10.

Wolfe, M.S., 1985. The current status and prospects of multiline cultivars and variety mixtures for disease resistance. Annu. Rev. Phytopathol. 23, 251-273.

Wolko, B., Clements, J., Naganowska, B., Nelson, M., Ha, Y. 2011. Lupinus. In: Kole C (ed) Wild Crop Relatives: Genomic and Breeding Resources. Springer, Heidelberg, pp 153-206

Worgan, G.B. 1788 (published 1978). Journal of a First Fleet Surgeon. Library Council of New South Wales, Sydney, Australia. http://purl.library.usyd.edu.au/setis/id/worjour

Woyengo, T.A., Beltranena, E., Zijlstra, R.T., 2014. Nonruminant nutrition symposium: Controlling feed cost by including alternative ingredients into pig diets: A review. J. Anim. Sci. 92, 1293-1305. 
Xue, Y., Xia, X., Christie, P., Zhang, Z., Li, L.,Tang, C., 2016. Crop acquisition of phosphorus, iron and zinc from soil in cereal/legume intercropping systems: a critical review. Ann. Bot. 117, 363-377.

Yates, R.J., Howieson, J.G., Reeve, W.G., O'Hara, W.G., 2011. A re-appraisal of the biology and terminology describing rhizobial strain success in nodule occupancy of legumes in agriculture. Plant Soil 348, 255-267.

Yunusa, I.A.M., Rashid, M.A., 2007. Productivity and rotational benefits of grass, medic pastures and faba beans in a rainfall limited environment. Soil Till. Res. 97, 150-161.

Zając, T., Oleksy, A., Stokłosa, A., Klimek-Kopyra, A., Kulig, B., 2013. The development competition and productivity of linseed and pea-cultivars grown in a pure sowing or in a mixture. Eur J Agron. 44, 22-31.

Zahran, H.H. 1999. Rhizobium-legume symbiosis and nitrogen fixation under severe conditions and in an arid climate. Microbiol. Mol. Biol. Rev. 63, 968-989

Zander, P., Amjath-Babu, T.S., Preissel, S., Reckling, M., Bues, A., Schläfke, N., Kuhlman, T., Bachinger, J., Uthes, S., Murphy-Bokern, D., Stoddard, F., Watson C.A., 2016. Can legume farming survive in Europe? A review on the drivers of its decline and the agro-economic challenges on its revival. Agronomy for Sustainable Development (DOI: 10.1007/s13593-016-0365-y)

Zentner, R.P., Wall, D.D., Nagy, C.N., Smith, E.G., Young, D.L., Miller, P.R., Campbell, C.A., McConkey, B.G., Brandt, S.A., Lafond, G.P., Johnston, A.M., Derksen, D.A., 2002. Economics of crop diversification and soil tillage opportunities in the Canadian prairies. Agron. J. 94, 216-230.

Zimmer, S., Messmer, M., Haase, T., Piepho, H.-P., Mindermann, A., Schulz, H., Habekuß, A., Ordon, F., Wilbois, K.-P., Heß, J., 2016. Effects of soybean variety and Bradyrhizobium strains on yield, protein content and biological nitrogen fixation under cool growing conditions in Germany. Eur. J. Agron. 72, 38-46.

Zhang, Y., Overland, M., Sorensen, M., Penn, M., Mydland, L.T., Shearer, K.D., Storebakken, T., 2012. Optimal inclusion of lupin and pea protein concentrates in extruded diets for rainbow trout (Oncorhynchus mykiss). Aquaculture 344/349, $100-$ 113.

Zuo, Y., Zhang, F., 2009. Iron and zinc biofortification strategies in dicot plants by intercropping with gramineous species. A review. Agron. Sust. Dev. 29, 63-71. 